\title{
Trabalho e subjetividade no contexto hospitalar: análise institucional do discurso produzido em grupo com profissionais de enfermagem da pediatria.
}

(versão corrigida)

\author{
Dissertação apresentada ao Instituto de \\ Psicologia da Universidade de São Paulo como \\ parte dos requisitos para a obtenção do grau de \\ Mestre em Psicologia. \\ Programa de Pós Graduação em Psicologia \\ Escolar e do Desenvolvimento Humano \\ Orientadora: Prof ${ }^{\mathrm{a}} \operatorname{Dr}^{\mathrm{a}}$ Marlene Guirado
}


AUTORIZO A REPRODUÇÃO E DIVULGAÇÃO TOTAL OU PARCIAL DESTE TRABALHO, POR QUALQUER MEIO CONVENCIONAL OU ELETRÔNICO, PARA FINS DE ESTUDO E PESQUISA, DESDE QUE CITADA A FONTE.

Catalogação na publicação

Biblioteca Dante Moreira Leite

Instituto de Psicologia da Universidade de São Paulo

Coelho, Ronaldo Lopes.

Trabalho e subjetividade no contexto hospitalar: análise institucional do discurso produzido em grupo com profissionais de enfermagem da pediatria / Ronaldo Lopes Coelho; orientadora Marlene Guirado. -- São Paulo, 2013.

$129 \mathrm{f}$.

Dissertação (Mestrado - Programa de Pós-Graduação em Psicologia. Área de Concentração: Psicologia Escolar e do Desenvolvimento Humano) - Instituto de Psicologia da Universidade de São Paulo.

1. Equipe de enfermagem 2. Pediatria 3. Hospitais públicos 4. Hospitais universitários 5. Trabalho 6. Psicologia organizacional 7. Análise do discurso I. Título. 
Nome: Coelho, Ronaldo Lopes

Título: Trabalho e subjetividade no contexto hospitalar: análise institucional do discurso produzido em grupo com profissionais de enfermagem da pediatria

Dissertação apresentada ao Instituto de Psicologia da Universidade de São Paulo para obtenção do título de Mestre em Psicologia

Aprovado em:

Banca Examinadora

Dr.

Instituição:

Assinatura:

Dr.

Instituição: Assinatura:

Dr.

Instituição: Assinatura: 
Aos que vieram antes, com muita gratidão... $\mathbf{E}$ aos que porventura ainda virão, com carinho... 


\section{AGRADECIMENTOS}

À Profa. Dra. Marlene Guirado, pela construção de um método fértil e por ensinar-me essa estratégia de pensar que possibilita ver o mundo de outra forma justamente por se deter àquilo que é reconhecido como natural e que de tão óbvio passa desapercebido.

À querida Dra. Juliana Davini... Algumas pessoas cruzam nossas vidas como anjos montados em cometas... e em sua aparição meteórica mudam o rumo da história. Sem ela certamente esse trabalho não teria chegado onde chegou.

Ao sábio e querido Pedro Dantas, pela imensurável generosidade, rigor e atenção na revisão desse trabalho...

À Coordenação de Aperfeiçoamento de Pessoal de Nível Superior (CAPES), pela concessão da bolsa de mestrado.

Ao querido amigo Luis Miguel, pela ajuda paciente na tradução do Resumo deste trabalho para a língua inglesa.

Aos meus pais... Sinônimo de vida e superação!

Ao Prof. Dr. Avelino Luiz Rodrigues, a quem devo a decisão de exercer a profissão de psicólogo, pela confiança sempre creditada e pela amizade sem palavras.

Ao amigo Roberto Telles... sempre presente, "mesmo que o tempo e a distancia digam não", pela abertura inicial de meus olhos para a beleza do mundo.

À Prof. Dra. Maria Luiza Sandoval Shimidt, pelo olhar sempre atento e carinhoso na postura firme.

À Ludmila, a quem devo a decisão pelo aprofundamento dos estudos na carreira acadêmica, a quem devo tanto... o indizível de minha gratidão.

À Martha Dantas, por estar ao meu lado nos bons e nos maus momentos, pela paciência e cuidado característicos de uma parceria sem fronteiras para as dores e as delícias do viver.

Às enfermeiras que participaram do grupo, o mais genuíno obrigado.

A toda a equipe da Clínica Pediátrica, pela abertura e calorosa acolhida.

A toda a equipe da Clínica Médica, pela possibilidade de me tornar de fato um psicólogo hospitalar. 
A todos os professores que passaram pela minha vida.

Aos colegas do laboratório CHRONOS, pelas alegrias e tristezas que passamos juntos.

Aos colegas do grupo de orientação pelas leituras atentas e rigorosas.

Ao grupo Invenções e Redescrições Analíticas, que mostrou-me Freud e a psicanálise sob outras lentes.

Aos meus pacientes e alunos, que tanto me ensinam...

A todos aqueles que de algum modo colaboraram com minha formação como psicólogo e pesquisador:

Ao Laboratório NEPAIDS e à Profa. Dra. Vera Paiva, quem esteve comigo nos meus primeiros passos no campo da pesquisa.

À Profa. Dra. Leny Sato, com indescritível admiração...

À Profa. Dra. Fátima Queiroz, por abrir as portas para minha atuação na UNIFESP.

Aos amigos Dailza Pineda, Rubens Bias, Farley Leandro, Luciano Salen Daie, André Felipe (Nenê), Juliana Queiroz, Gilberto Dias, Bárbara, Ricardo (Magrão), Karina Brancher, Kailash (Kaká), Rafinha, Léia, Andrea, Rafael (Nego) e tantos outros... pela presença que torna a vida mais leve... e nos leva a acreditar que vale a pena viver...

Agradeço também a tudo aquilo que me foi negado ou de que fui privado, bem como as coisas ruins que recebi, por fazer brotar força, paciência e coragem, os melhores presentes que a vida pode dar... eles foram fundamentais na construção dos caminhos que trilhei e serão, sem dúvida, base sólida e concreta para prosseguir. 
Existem momentos na vida onde a questão de saber se se pode pensar diferentemente do que se pensa, e perceber diferentemente do que se vê, é indispensável para continuar a olhar ou a refletir.

Michel Foucault 


\section{RESUMO}

Coelho, R.L. (2013). Trabalho e subjetividade no contexto hospitalar: Análise institucional do discurso produzido em grupo com profissionais de enfermagem da pediatria. Dissertação de Mestrado, Instituto de Psicologia, Universidade de São Paulo, São Paulo

A presente pesquisa tem como objetivo realizar uma análise institucional do discurso produzido em grupo por profissionais da equipe de enfermagem da Clínica Pediátrica de um hospital escola da rede pública de saúde da cidade de São Paulo. Nossa análise foca a relação que este profissional estabelece com o trabalho a partir do referencial metodológico conceitual da Análise Institucional do Discurso desenvolvido por Guirado (2010). Como produto desse estudo demonstramos que a relação construída pelas profissionais no e com o trabalho é entretecida por procedimentos, sejam eles de ordem predominantemente administrativo-gerencial no caso das enfermeiras, ou da ordem do cuidado-curativo predominantemente encontrado no fazer das técnicas e auxiliares de enfermagem. Esse entrelaçamento entre procedimento e relação acarreta indistinção entre ser e fazer no modo como as profissionais se constituem subjetivamente, abrindo, assim, caminho à produção de forte identificação com o papel de mãe, à indiferenciação na relação com o paciente e à dificuldade na constituição de contornos que ofereçam limites à sua prática e a seus sentimentos. Nesse sentido, a morte se constitui como único limite inexorável e produz desestruturação e reorganização de si e da relação com o trabalho, mas também pode produzir trauma, paralisia, repetição e pânico. A mãe é compreendida como o lugar-referência por excelência para a criança. Quando boa é base para a vida, saúde e felicidade do filho. Quando ruim ou ausente é a causa do desalinho, fragilidade, doença e morte da criança. As mães são ao mesmo tempo agentes institucionais e clientela, o trabalho da enfermagem prevê o da mãe. A carga de trabalho da enfermagem é aliviada quando a mãe é boa, e aumenta quando a mãe é má. A criança aparece como objeto-alvo da ação da enfermagem e como sujeito-produto de sua mãe. O jogo de poder/resistência na relação com os médicos ocorre em meio a uma polarização entre fazer viver e deixar morrer, na qual a resistência implica assumir o lugar do médico, "tomar conduta" e fazer viver. Com os profissionais do âmbito da justiça esse jogo ocorre em torno da sentença sobre o futuro da criança, contudo, apartadas de todo o "processo" as profissionais resistem julgando o julgamento. Ironia, deslegitimação, denúncia e alarde, "falta de comprometimento", esgarçamento de limites e fronteiras são as principais estratégias de resistência das quais fazem uso. De outro lado, como manutenção do funcionamento institucional temos a rígida estrutura hierárquica, processos jurídicos e administrativos, punição e "conversa", o apaziguamento, cujo papel o grupo aqui analisado cumpriu. Por fim, por meio desta pesquisa configuramos como objeto institucional da enfermagem a manutenção e controle de todos os movimentos e alterações do e no paciente, quer sejam motores ou físiológicos, por meio de tecnologias de monitoramento e vigilância, gratificações e punições.

Palavras-chave: Equipe de enfermagem. Pediatria. Hospitais públicos. Hospitais universitários. Trabalho. Psicologia organizacional. Análise do discurso. 


\begin{abstract}
Coelho, R. L. (2013). Work and subjectivity in a hospital environment: institutional analysis of the discourse of a group of nurses of the Pediatric unity of the hospital. Dissertação de Mestrado, Instituto de Psicologia, Universidade de São Paulo
\end{abstract}

The main goal of this research is to make an institutional analysis of the discourse of a group. For this assignment a São Paulo's public teaching hospital was chosen. The focus of our analysis is the relationship the professional has with his work, using the Institutional Analysis of Discourse, developed by Guirado (2010), as a conceptual and methodological reference. This research will demonstrate that the professionals' relationship with their work is tangled up by procedures, majorly composed by administrative and caring procedures (for nurses and auxiliary nurses, respectively). The blending of procedures and relationship disguises the differences between being and doing, leading in turn to the nurses' identification with the mother's role, to the indiscriminateness' of their relationship with the patients, and to an increased difficulty when defining the limits for their practice and their feelings. In that case, death is for them the only inexorable limit, one that promotes the disruption and reorganization of themselves and their relationship with the work. Death is also able to promote trauma, paralysis, repetition, and panic. The mother is seen, by the child, as a true and only haven. If the mother is good, she is considered the foundations for life, health and happiness of the child. When she is bad or absent, this is considered the reason for the child's untidiness, fragility, illness and death. The mothers are, simultaneously, institutional agents and clientele, since the nursing work presupposes the work of the mother. The amount of work attributed to that staff is lessened in the presence of a good mother and enlarged when dealing with a bad mother. The child appears as object and target of the nurses' action and as subject and product of your mother. The dispute for power (and its resistance) in the contacts with the doctors occurs through the polarization between making the child to live or leaving the child to die, in which the resistance implies taking over the doctor's job, "take conduct" and making the child to live. With the professionals in the domain of Justice, these games of power/resistance occur concerning the sentence about the child's future. Nevertheless, nurse professionals, kept away from the "process", resist by judging the judgment. Irony, disqualifying, indictment and boasting, lack of commitment, and the blurring of limits and boundaries are the primary resistance strategies which they employ. On the other hand, acting as institutional functioning support maintenance we have a rigid hierarchic structure, juridical and management proceedings, punishment and "discussion", and pacification (whose role was fulfilled by the group here studied). At last, the maintenance and control of all patient's alterations and movements (physical or physiological) was configured as the institutional object for the nursing work. This was achieved by means of monitoring and surveillance technologies, rewards and punishments.

Keywords: Nursing Team. Pediatrics. Public hospital. University hospital. Work. Organizational psychology. Analysis of the discourse. 


\section{LISTA DE TABELAS}

Tabela 1 - Tabela demonstrativa do tempo que as participantes tem de profissão, titulação, nível hierárquico no HE e se já trabalharam em outro hospital ou aparelho de saúde antes e por quanto tempo 36

Tabela 2 - Pesquisa de artigos sobre aspectos psicológicos do trabalho de profissionais de enfermagem 


\section{Sumário}

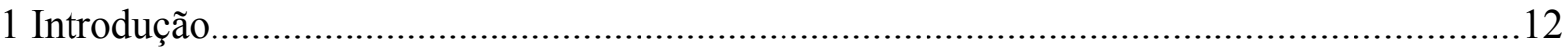

1.1 Do estudante ao psicólogo e pesquisador: a história de um percurso...........................12

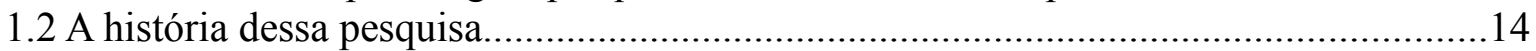

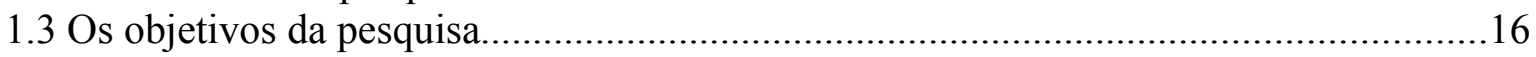

2 Considerações sobre a organização hospitalar....................................................................18

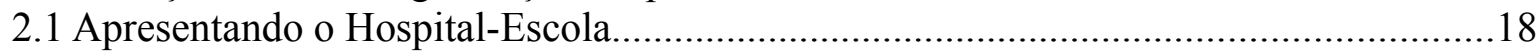

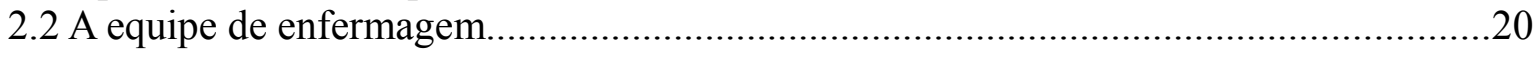

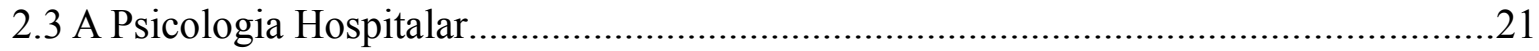

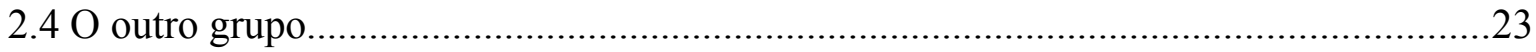

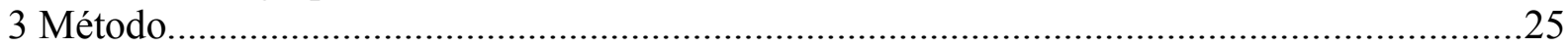

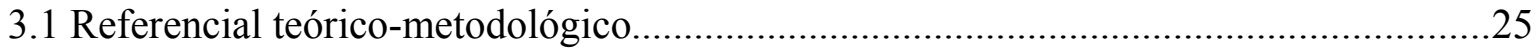

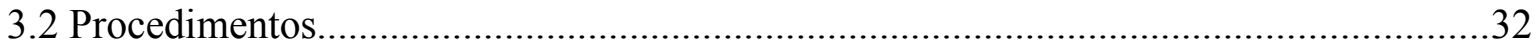

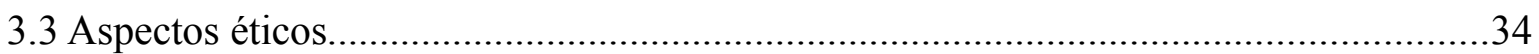

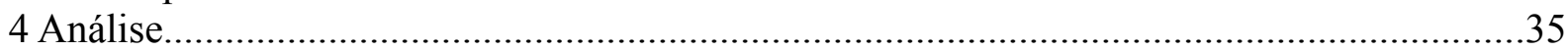

4.1 A configuração do grupo na relação com o Hospital-Escola e a Pediatria.......................36

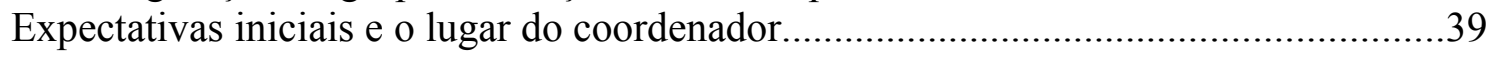

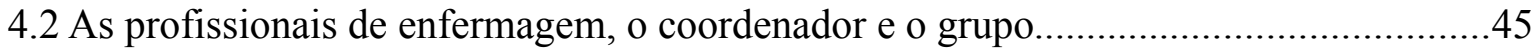

As enfermeiras de nível superior, suas técnicas e suas auxiliares...............................46

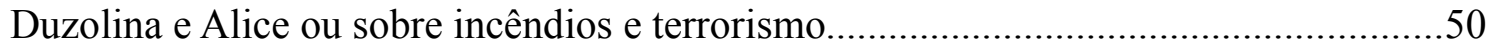

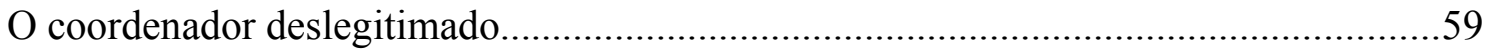

A construção de um lugar de legitimidade para o coordenador....................................63

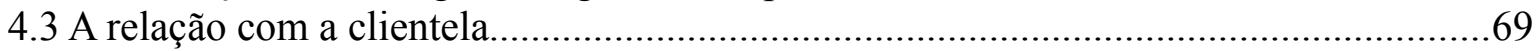

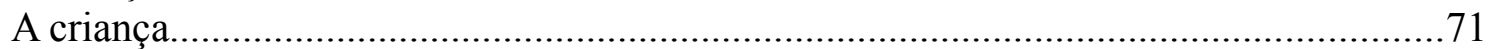

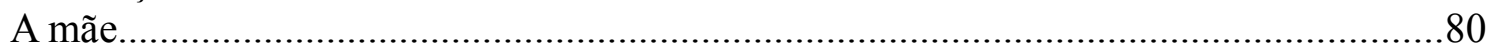

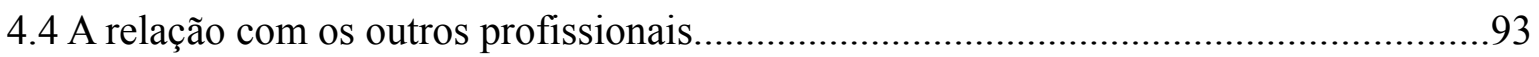

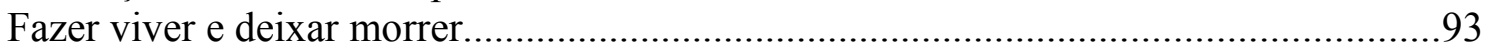

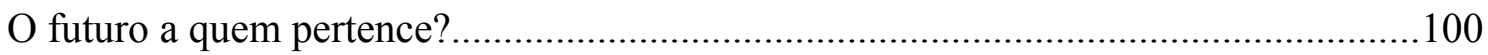

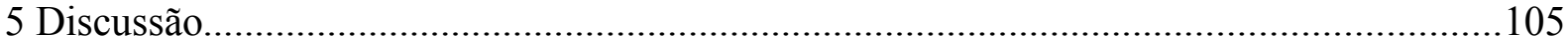

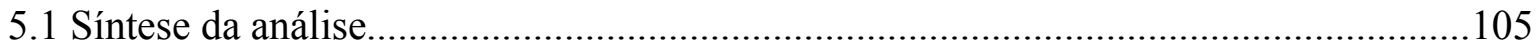

5.2 Pesquisas envolvendo o trabalho de profissionais de enfermagem.............................111

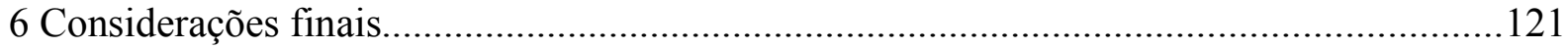

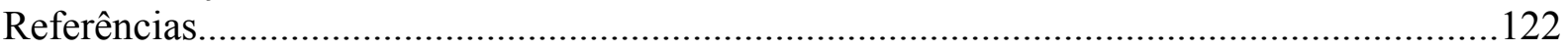

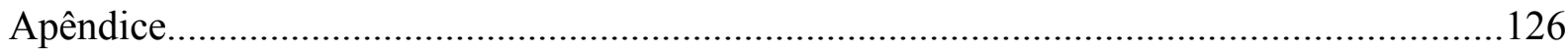




\section{Introdução}

\subsection{Do estudante ao psicólogo e pesquisador: a história de um percurso $^{1}$}

A história dessa pesquisa começa pela história da constituição de um pesquisador. Quando escolhi cursar psicologia não tinha, ainda, decidido ser psicólogo, tinha apenas optado por estudar aquilo que vagamente eu compreendia pelas palavras subjetividade, mente, psique...

Sem me alongar no assunto, vale colocar por motivo de curiosidade que antes de eu decidir fazer psicologia um planejamento familiar tinha por objetivo que eu me tornasse oficial das forças aéreas brasileira. Projeto esse com o qual eu estava de acordo e me esforçava para que se concretizasse.

Dois eram os entraves que me colocavam de modo pouco simpático no curso de Psicologia desde antes de realizar a matrícula. O primeiro era o estereótipo de que o psicólogo "sabe o que está se passando na mente do outro" e o segundo era a constituição histórica do caráter elitizado da clínica, seguindo o padrão do consultório particular e do seting psicanalítico tradicional. Todo meu percurso se desenvolveu, deste modo, tendo como norte o polo oposto a essas duas ideias.

Logo no começo do primeiro ano participei do comando de greve do Instituto de Psicologia (IP) e compus uma chapa para o Centro Acadêmico, a qual realizou sua gestão no ano de 2005. Desde então, sempre mantive ligação com o Movimento Estudantil (ME) de algum modo ${ }^{2}$. No ME aproximei-me de colegas que à época se interessavam muito por Psicologia Social, Processos Grupais e Psicologia Institucional, o que me mobilizou a estudar e realizar experiências nessas áreas. E foi apenas em 2007, quando realizei o curso de Psicologia Institucional, ministrado pela Profa. Dra. Marlene Guirado, que tive contato com a Análise Institucional do Discurso (AID), método por ela desenvolvido (Guirado, 2000, 2004a, 2004b, 2006, 2010; Guirado \& Lerner, 2007). Encantei-me como quem se apaixona a

1 Parece-nos relevante começar por apresentar o autor deste trabalho de uma maneira autobiográfica.

2 Hoje estou como Representante Dissente da Congregação do IP. 
primeira vista por esse modo de pensar. No ano seguinte a Profa. Marlene me convidou para ser monitor de graduação na referida disciplina, tendo como função auxiliar na orientação da produção de uma pesquisa com o método da AID. De imediato topei o convite e, desde então, a todo ano venho participando da parte prática de Psicologia Institucional nessa função.

Em 2008, enquanto trabalhava como coordenador do Cursinho Pré-Universitário da Psico, foi o momento em que se acirrou a dúvida acerca da continuidade do curso de Psicologia. Apesar de me interessar e procurar estudar desde cedo a psicologia que se propunha a cumprir com os mesmos ideais que $e^{3}$, por vezes acreditava que não era bem o que queria fazer da minha profissão.

Em meio a essa crise começaram os atendimentos clínicos que fazia sob a supervisão do Professor Avelino Luiz Rodrigues. Curiosamente, interessei-me pela psicanálise, sempre, contudo, de maneira desconfiada. Encantava-me, principalmente, o que abria de possibilidades para a existência de uma pessoa o fato dela realizar uma sessão de terapia por semana. Passei a gostar do trabalho clínico, mas considerava que eu não levava jeito para a coisa, que não era bom o suficiente, além de ter os dois entraves supramencionados, que me acompanhavam desde o início do curso e impediam de seguir por esse caminho.

Comecei a aprofundar meus estudos em AID com a Professora Marlene Guirado e iniciei minha Iniciação Científica com os profissionais da equipe do Programa Saúde da Família de uma Unidade Básica de Saúde da cidade de São Paulo sob a orientação da Professora Maria Luiza Sandoval Schmidt. O objetivo da pesquisa era o de estudar as relações de poder, as estruturas burocráticas e a produção de subjetividade daquele arranjo institucional pelo método da AID.

Quando terminei a pesquisa faltavam pouco menos de três semestres para concluir a graduação. Àquela época, eu pensava em fazer uma pós-graduação na área da Educação ou nas Ciências Políticas, e/ou talvez entrar para um partido político de esquerda... Mas não pensava em exercer a profissão de psicólogo.

Mesmo depois de deixar de ser meu supervisor de atendimento clínico, o Professor Avelino e eu mantivemos um contato próximo. Por vezes ele deixava escapar sua opinião de que eu deveria seguir carreira como psicólogo na área da saúde. Segundo ele, tinha tudo a ver comigo. Suas palavras não me convenciam. Eu acreditava que elas diziam muito mais de um 3 Psicologia Social, do Trabalho, Escolar, Institucional, Grupos. 
desejo dele do que de características minhas. Além disso, outro preconceito meu, de que psicólogo hospitalar era nada mais que um médico frustrado, contribuía para a minha indisposição a qualquer experiência na área da saúde.

Ao final deste ano de 2008, porém, um convite de trabalho de um querido amigo fezme deparar com o fato de que eu nada sabia sobre a conduta do psicólogo na área da saúde, mais especificamente na área hospitalar, e que provavelmente não pudesse aceitar a proposta caso ela se concretizasse. Foi então que procurei o Professor Avelino com o objetivo de estagiar num hospital. Ele atendeu com entusiasmo e prontidão ao meu pedido, e no início de 2009 comecei como estagiário na Pediatria.

Já no meu primeiro dia no hospital senti algo que nunca tinha sentido antes no que diz respeito à minha escolha profissional: Era aquilo mesmo que eu queria fazer da minha vida ${ }^{4}$. Percebi que era um trabalho altamente necessário e me sentia útil por acreditar que poderia fazê-lo com qualidade. Este foi o dia em que decidi ser psicólogo.

Não foi necessário tempo de prática, mesmo como estagiário, para perceber que havia conhecimentos a serem desenvolvidos nesta área de atuação do psicólogo. Somada à minha história de vida, essa constatação fez com que surgisse o desejo de me tornar produtor de conhecimentos e formador de profissionais nessa área. Por fim, a ideia de fazer a pósgraduação com o objetivo de posteriormente vir a ser professor universitário.

\subsection{A história dessa pesquisa}

O fato de decidir trabalhar com construção de conhecimento e realizar o mestrado não define o que seria o objeto da pesquisa. Como vimos, desde cedo dediquei-me ao estudo de Processos Grupais e Psicologia Institucional, e meu percurso fez com que me encantasse com as áreas relacionadas a trabalho, educação e, somente no fim do curso, saúde.

Havia um interesse meu em uma conciliação desses elementos. O desenho que mais próximo chegou do desejo inicial foi: trabalhar com o discurso produzido em grupo; com o

4 Neste mesmo dia mandei um e-mail para o Professor Avelino contando dessa experiência e do que ela havia provocado em mim, bem como a decisão de me tornar psicólogo para trabalhar no hospital e o porquê. Em sua resposta, sem duvida alguma animada e orgulhosa, Avelino diz apenas: "Eu já sabia! Rs..." 
método da Análise Institucional do Discurso; focar na relação que os profissionais desenvolvem com o seu trabalho. Por fim, acabei optando por desenvolver a pesquisa com profissionais da área da saúde em detrimento dos da área da educação.

No início, a ideia era constituir um grupo com todas as categorias profissionais que trabalhassem na pediatria do hospital, de acordo com o critério de interesse. Com o tempo a pesquisa foi se desenhando de modo a se restringir à equipe de enfermagem.

Concomitantemente a esses movimentos do ponto de vista do interesse pessoal, eu verificava que havia entre as profissionais da pediatria uma grande disposição em falar sobre o trabalho e que os assuntos conversados na sala de café se davam de modo apressado, muitas vezes sem uma reflexão mais aprofundada, que resultava numa imediata reorganização de acordo com o que definiam naqueles poucos minutos, sem muito se aterem às possíveis produções decorrentes daquela decisão.

Um exemplo marcante nesse sentido foi, inclusive, o organizador primeiro dessa pesquisa. Uma senhora, mãe de um paciente, se movimentava de maneira notavelmente irritada no corredor da pediatria. Perguntei-lhe se precisava de algo, e foi quando ela começou a se exaltar ainda mais. Ao mesmo tempo senti que para ela estava sendo bom alguém se dispor a ouvi-la. Convidei-a, então, para conversarmos numa sala onde pudesse ser garantida alguma privacidade à conversa. De modo sucinto, o que ela refere ter provocado sua ira era a conduta da assistente social diante da visita da diretora do colégio onde o filho dela estudou. Essa mãe acreditava que o estado de saúde atual do filho era decorrente de uma briga na escola, situação na qual outra criança teria batido com um pedaço de madeira na cabeça dele. O diagnóstico, contudo, apontava para uma neuropatia infecciosa degenerativa grave. Esta mãe, moradora de rua e analfabeta, não compreendia que o acontecimento na escola não tinha relação causal com o desenvolvimento da doença de seu filho e culpava a escola e sua diretora. Em uma das entrevistas com a assistente social ela havia verbalizado que agrediria a diretora caso a encontrasse. A assistente social, por sua vez, na ocasião da visita da diretora ao hospital, ao ver a mãe se aproximar, antecipou-se e a impediu de chegar à diretora com o intuito de protegê-la. Esse gesto, segundo a mãe, foi desnecessário e violento.

Ao sair desse atendimento, encontro alguns profissionais, em sua maioria da enfermagem, na sala de café. O assunto era essa mãe. Falavam do quanto ela era "violenta" e do como elas passariam a tratá-la na "mesma moeda". Aterrorizou-me o modo como as 
profissionais rapidamente se organizaram em contra-ataque coletivo em defesa de uma de suas colegas de trabalho. De súbito, coloquei-me na conversa com o intuito de "mostrar o outro lado", de fazerem refletir sobre o que fariam e o que produziriam com seus atos. Para mim era claro que as profissionais da enfermagem não poderiam agir com um comportamento corporativista revanchista para cima daquela senhora. $\mathrm{O}$ que fez com que mesmo sendo recém-chegado eu me colocasse na conversa. ${ }^{5}$

Notei que ao final somente uma técnica de enfermagem me ouvia, e era justamente a técnica que estava cuidando do filho da senhora de quem estávamos falando, e que para ela essa conversa tinha provocado algum efeito. Ela saiu diferente de como havia entrado na sala de café, mas não por isso fragilizada ou colocando em cheque a sua capacidade profissional. Ela parecia refletir sobre o que faria a partir do lugar de quem tem a função de cuidar daquela mãe.

Posto que havia uma convergência com meus interesses pessoais, a partir desse dia passei a organizar "os bastidores" para que montássemos um grupo que tivesse como objetivo discutir sobre as questões do trabalho na enfermaria da pediatria. E pouco a pouco a presente pesquisa foi se desenhando.

Por fim, o grupo foi criado com a proposta de ser um espaço no qual seria discutido o trabalho da pediatria e, nele, os profissionais poderiam falar livremente. Foi informado, também, que com o consentimento dos participantes os encontros seriam gravados, transcritos e a analisados para os fins dessa pesquisa de mestrado.

\subsection{Os objetivos da pesquisa}

Nosso objetivo nessa pesquisa é realizar uma analise institucional do discurso

5 Busquei mostrar o quão frágil era aquela mãe que mal tinha onde morar; o quanto poderia estar assustada com tudo aquilo; que provavelmente ela não estava conseguindo entender nada da situação; que havia um choque de culturas, mais que um mero descuido ou violência por parte de suas ações; mas, principalmente, que as profissionais de enfermagem, cada uma, sozinha, já era mais forte do que aquela mãe e que aquele conluio era antes de tudo covardia; que elas, como profissionais de saúde, poderiam utilizar de outros meios para se protegerem, mas que deveriam lidar com as mães como se fossem pacientes, como alguém que demanda cuidado por parte dos profissionais do hospital e que, em meio a isso, seria necessário atentar para o fato de que agiriam na contramão de cuidar dessa mãe se prosseguissem com o "plano". 
produzido em grupo por profissionais da equipe de enfermagem da Clínica Pediátrica de um hospital escola da cidade de São Paulo com foco na relação com o trabalho que desenvolvem.

A Análise Institucional do Discurso, desenvolvida por Marlene Guirado, nos servirá de alicerce metodológico por meio do qual buscaremos caracterizar/ configurar: 1) a relação que as profissionais desenvolvem com a prática que exercem cotidianamente; 2) os sentidos atribuídos ao trabalho, sua organização e as relações que por meio dele se dão; 3) as naturalizações, os efeitos de reconhecimento e desconhecimento das práticas e relações institucionais; 4) que relação desenvolvem com a clientela, entre elas próprias e com outros profissionais; 5) a amplitude de ação característico de cada lugar institucional, as tensões e os jogos de força intrínsecos à relação; 6) o jogo de expectativas que se estabeleceu na relação com o objetivo da pesquisa, com a proposta do grupo e com o coordenador; 7) por fim, os pontos de tensão e as estratégias que enredavam os atores em ato no grupo, considerando o lugar atribuído e o assumido pelo coordenador, pois seu discurso também é discurso em análise. 


\section{Considerações sobre a organização hospitalar}

Como vamos trabalhar em um hospital e com profissionais de enfermagem, cabe algumas considerações iniciais para apresentarmos de que tipo de organização estamos falando e qual o lugar reservado à enfermaria da pediatria. Nessa apresentação, buscaremos delinear alguns elementos que dizem da forma como está organizado o trabalho da equipe de enfermagem neste hospital e nesta unidade. Cabe também falar um pouco da história da psicologia em hospital e especificamente neste hospital, pois será fundamental para compreendermos o jogo de expectativas perceptíveis em algumas das colocações tanto por parte do coordenador quanto por parte das profissionais.

\subsection{Apresentando o Hospital-Escola.}

O hospital no qual desenvolvemos a pesquisa será aqui chamado de Hospital-Escola (HE). Sua organização é a de um hospital geral, compreendendo as quatro clínicas básicas: Clínica Médica, Clínica Cirúrgica, Clínica Pediátrica e Clínica Ginecológica e Obstétrica. Cada uma delas possui sua própria enfermaria onde os pacientes ficam internados para observação ou tratamento. O HE possui 25 leitos em Unidade de Tratamento Intensivo (UTI), sendo 14 em UTI Adulto, 6 em UTI Pediátrica e 5 em UTI Neonatal; possui também ambulatórios com 57 consultórios, nos quais se atende a população em caráter de consulta médica; Pronto Atendimento, com 13 consultórios; 17 salas de aula; 5 anfiteatros. A capacidade ocupacional e instalada é de, ao todo, 258 leitos ${ }^{6}$

Nosso trabalho, repetimos, foi realizado na enfermaria da Pediatria, com os profissionais que atuam diretamente no contato com a clientela, com a doença e o dia a dia desta Unidade. Portanto, vamos a ela.

\section{A enfermaria da Pediatria}

A enfermaria da Clínica Pediátrica atende crianças e adolescentes hospitalizados para

6 As informações são do site oficial do hospital. 
receber cuidados especiais, ali permanecem o tempo que for necessário, ou seja, até a alta hospitalar, a transferência para outra unidade ou outro hospital ou em caso de óbito. Durante o período de nossa pesquisa o quadro profissional era composto por equipe de enfermagem, medicina, nutrição, fisioterapia, terapia ocupacional, psicologia, serviço social e brinquedista ${ }^{7}$. Contava com quartos coletivos, quartos de isolamento (para casos de risco de contágio), uma brinquedoteca, computadores para jogos e televisão. Como é habitual nos hospitais, os quartos são numerados de modo a possibilitar uma organização esquadrinhada, como uma matriz matemática, da alocação dos pacientes de acordo com a faixa etária. Segundo os responsáveis pela Unidade, há uma preocupação em tornar o período de internação o menos invasivo e disruptivo possível na vida da criança, ou adolescente. Cada paciente pode ter um acompanhante - em geral a mãe - em tempo integral. Muitas vezes o acompanhante precisa aprender a realizar os procedimentos indispensáveis à concessão da alta hospitalar ao paciente, como por exemplo, procedimentos de aspiração para pacientes traqueostomizados. Nesses casos os acompanhantes são treinados pela equipe de saúde da própria enfermaria.

O processo de alta hospitalar obedece a uma série de procedimentos: avaliação das condições físicas, orgânicas e psicológicas do paciente; avaliação das condições socioeconômicas do cuidador e/ou da família; verificação da existência de uma pessoa habilitada e disponível para ocupar a função de cuidador, quase sempre a mãe; acionamento da "rede" ${ }^{8}$ para encaminhamento, quando necessário, para o cuidado integral do paciente. $\mathrm{O}$ HE possui um programa de acompanhamento domiciliar que auxilia a equipe na decisão sobre a "alta" e acompanha o tratamento do paciente em sua residência enquanto o mesmo for necessário, isto é, em caso de alta hospitalar definitiva ou em caso de óbito.

Uma vez por semana ocorre uma reunião da qual participa ao menos um representante de cada categoria profissional ${ }^{9}$. Nessa reunião são discutidos os assuntos

7 Tanto os psicólogos quanto os terapeutas ocupacionais não eram contratados do hospital, mas atuavam na enfermaria por parceria com laboratórios de outras instituições. Outras categorias profissionais que aqui não foram mencionadas atendiam na enfermaria por meio de interconsulta, por isso não estão aqui discriminados. No caso da brinquedista, ela contava com voluntários, que na maior parte das vezes não eram da área da saúde, em períodos pré-estabelecidos para auxiliar com as crianças.

8 Compreende-se por "rede" os aparelhos estatais de saúde, e proteção social.

9 Numa das reuniões multidisciplinares esse assunto foi tratado. Os técnicos e auxiliares de enfermagem não participam da reunião, ao mesmo tempo são esses profissionais os mais próximos ao paciente e aos acompanhantes, não só por serem eles que realizam a grande maioria dos procedimentos, mas também pela proximidade socioeconômica e cultural. Contudo, eles não participam porque a representante da equipe de enfermagem sempre é uma enfermeira de nível superior, de preferência a chefe da equipe. O mesmo acontece com a equipe médica. É o médico responsável pela enfermaria que coordena a reunião e ele é o representante da equipe. 
referentes à enfermaria: os pacientes de internação recente, os que tiveram alta e, principalmente, os “casos difíceis". Esses exigem uma prática mais apurada com a qual se busca orientação pela interdisciplinaridade e pelo respaldo no trabalho em equipe. Trata-se de decisões éticas e técnicas de difícil manejo, por exemplo, a decisão de realizar um protocolo de procedimentos de cuidados paliativos em uma criança que não apresenta resposta satisfatória para a continuidade do tratamento terapêutico.

Algumas situações são exclusivas da Pediatria, justamente por se tratar de crianças. O hospital é responsável legal pelas crianças nele internadas. Muitos casos devem ser encaminhados para uma instância jurídica, seja o Fórum ou o Conselho Tutelar, para avaliação e/ou decisão sobre procedimentos a serem tomados a respeito de encaminhamentos e/ou acompanhamento da conduta dos responsáveis legais. São eles os casos de abuso, negligência, maus tratos por parte dos pais ou dos detentores da guarda, entre outros que coloquem em risco a integridade física e psicológica da criança/adolescente. Parte-se do princípio de que as crianças são indefesas, e o hospital, como aparelho do Estado, deve contribuir na promoção da segurança delas. Muitas vezes, a criança apresenta condições físicas e psicológicas satisfatórias para a concessão da alta, mas não pode recebê-la, pois o "processo" ainda não foi liberado nas instâncias jurídicas.

O cotidiano da clínica é recheado desses casos "insolúveis", e neles o bom não se restringe ao melhor cuidado prestado à saúde da criança. Casos de internações reincidentes, longas, que passam a "fazer parte" da enfermaria são comuns. No capítulo de análise examinaremos melhor essa questão.

\subsection{A equipe de enfermagem}

É formada por enfermeiros de nível superior, técnicos e auxiliares de enfermagem. De acordo com a hierarquia do hospital, cabe aos enfermeiros chefiar uma equipe composta por técnicos e auxiliares. No caso do HE, a enfermaria é dividida em ala par e ala impar, cada uma delas com um enfermeiro responsável para cada turno.

Tal qual a equipe médica, tem sua própria hierarquia. Disso decorre, por exemplo, que 
cada unidade tenha um chefe por parte da equipe médica e outro por parte da equipe de enfermagem. A chefe da enfermaria trabalha no período denominado "horário administrativo", por oito horas durante os cinco dias da semana. Quanto aos demais profissionais da equipe de enfermagem, durante a semana, quem trabalha nos períodos da manhã e tarde tem jornada de trabalho de seis horas, e os do período noturno obedecem esquema alternado de doze horas de trabalho por trinta e seis de descanso. Nos finais de semana e feriados todos os períodos funcionam no esquema de doze por trinta e seis. Por meio de uma escala mensal de trabalho se define os dias de folga aos quais os profissionais têm direito $^{10}$.

\subsection{A Psicologia Hospitalar}

Por se tratar de intervenção num hospital, será oportuno saber um pouco do modo pelo qual a Psicologia se inseriu nesse contexto para nos ajudar a compreender o lugar que o psicólogo foi ocupando. Segundo o vídeo "Uma questão de Saúde: Trajetória da Psicologia Hospitalar em São Paulo" (www.crpsp.org.br), o ingresso da Psicologia no hospital geral se deu em 1954 com a psicóloga Matilde Neder ${ }^{11}$, a pedido do chefe do Grupo de Cirurgia de Coluna do Instituto de Ortopedia e Traumatologia do Hospital das Clínicas da Faculdade de Medicina da Universidade de São Paulo, para atendimento das crianças submetidas a cirurgia e familiares. As entrevistas exibidas no filme mostram que, desde o início, a atuação dos psicólogos nos hospitais se deu nas enfermarias das pediatrias e tentou se desenvolver com uma proposta multidisciplinar ${ }^{12}$, fornecendo atenção e suporte não só aos pacientes e familiares, mas também aos profissionais de saúde, por meio de discussão de casos clínicos e de formas de intervenção, discussões sobre incômodos e papéis de cada profissional nas circunstâncias ali encontradas. O registro e a publicação dessas experiências visava contribuir para a formação de todos os profissionais de saúde (Vídeo CRP-SP).

10 No capítulo de Análise, veremos como as profissionais se relacionam com essa forma de organizar o trabalho.

11 A Lei n ${ }^{\circ} 4.119$, que cria a Profissão de Psicólogo, data de 27 de agosto de 1962. No entanto, cabe lembrar que antes a psicologia era uma especialidade da filosofia.

12 Foi com o governo de Franco Montoro entre 1983 e 1987 que vemos uma ação do Estado para inserção de psicólogos na rede pública de saúde. 


\section{A Psicologia no Hospital-Escola}

Para compreender de que lugar institucional partimos quando propusemos o presente trabalho, vale dizer da história da Psicologia neste hospital.

No HE os primeiros atendimentos com Psicologia Hospitalar se iniciaram no ano de 1999 quando da parceria estabelecida entre o hospital e o Laboratório CHRONOS - Centro Humanístico de Recuperação em Oncologia e Saúde - do Departamento de Psicologia Clínica do Instituto de Psicologia da Universidade de São Paulo. Apesar de o hospital contar com psicólogas em seu corpo de profissionais, elas sempre atendiam em caráter ambulatorial, com consultas pré-agendadas. É recente, portanto, a prática da psicologia nas enfermarias, com psicólogos de plantão para realizar atendimentos em caráter de interconsulta e ligação (Nogueira-Martins, 2010).

Segundo a Profa. Elisa Maria Parahyba Campos, fundadora do Laboratório CHRONOS, a entrada dos psicólogos se deu por intermédio de um convite da Superintendência do HE, a qual sugeria ao CHRONOS realizar atendimentos a pacientes de câncer internados nas enfermarias. De imediato a coordenação do Laboratório aceitou o convite e declarou interesse na criação de um Serviço de Psicologia Hospitalar que possibilitasse à equipe do CHRONOS atender não só pacientes de câncer, mas todos aqueles que a equipe de saúde julgasse necessário. Propunha-se, assim, um serviço que funcionaria por interconsulta. O Serviço de Psicologia Hospitalar se consolidou em parceria com o Serviço de Psiquiatria, constituindo um grupo coordenado sempre por um psiquiatra. Desse modo, o Laboratório CHRONOS passou a se responsabilizar por todos os atendimentos em Psicologia Hospitalar, mas sem constar do organograma do hospital, pois todos os psicólogos profissionais que trabalhavam no serviço colaboravam de forma voluntária e não como funcionários.

À época em que essa pesquisa foi realizada, o protocolo para os pedidos de interconsulta respeitavam o seguinte formato: Um médico solicitava interconsulta à Psiquiatria, que avaliava o paciente e, caso julgasse pertinente, solicitava interconsulta para a Psicologia Hospitalar. Além da interconsulta, a Psicologia Hospitalar podia realizar o que era chamado de Entrevistas Terapêuticas nos dias em que os psicólogos responsáveis por cada clínica estivessem de plantão. Esses atendimentos pautavam-se no modo de funcionamento de um serviço de ligação (Nogueira-Martins, 2010), no qual os psicólogos poderiam eles 
próprios identificar demandas, além de atender às solicitações de outras categorias profissionais que não os psiquiatras.

Minhas atividades na enfermaria da pediatria, de início como estagiário de psicologia e depois como psicólogo colaborador, consistia em participar da reunião multidisciplinar ${ }^{13}$ e realizar um plantão de cerca de quatro horas semanais, no qual atendia pacientes e seus acompanhantes e me colocava disponível a discutir questões trazidas pela equipe de profissionais, embora fosse a reunião multidisciplinar, que ocorria semanalmente, o espaço instituído de discussão de casos clínicos e planejamento de conduta terapêutica interdisciplinar. A estratégia de pensamento da Análise Institucional do Discurso (GUIRADO, 2000; 2004a; 2004b; 2006; 2007; 2010) já se constituía como referência importante para minha prática clinica desde os primórdios de meu trabalho no HE.

\subsection{0 outro grupo}

Antes dessa pesquisa, outro trabalho foi realizado junto às profissionais da equipe de enfermagem da Pediatria pela psicóloga Clarice Guimarães. À época dessa pesquisa Clarice era Vice-coordenadora do Laboratório CHRONOS e responsável pelos atendimentos da Psicologia Hospitalar na Clínica Pediátrica. Era, também, a referência do Laboratório para o hospital como um todo, sendo que os responsáveis pelas outras Clínicas também estavam submetidos hierarquicamente a ela. Ela estava no HE desde o inicio da parceria com o CHRONOS.

Em 2008 Clarice realizou o que chamou de "Grupo Balint adaptado"14, com a intenção de oferecer um suporte à equipe de auxiliares e técnicos de enfermagem. O "Grupo" tinha como objetivo promover uma reflexão acerca da relação que as profissionais

13 À época se discutia se a melhor palavra a ser utilizada seria multidisciplinar ou interdisciplinar. Uma vez que a primeira palavra significaria a reunião de profissionais distintos e que atuam de acordo com seus saberes na atenção ao paciente sem que um interfira em nenhum dos procedimentos do outro. Já a segunda significaria que a forma de organização do trabalho entre os profissionais resultaria que um auxilia ao outro com seus conhecimentos, o que provoca uma ampliação da visão sobre o paciente e possibilita interferência na concepção do diagnóstico, prognóstico e tratamento. Não chegamos à alteração de nome, provavelmente por isso ainda não estar completamente sedimentado e também por se mostrar menos importante no momento. $\mathrm{O}$ que aqui se mostra importante dizer é que na concepção deste pesquisador a reunião possui caráter interdisciplinar, contudo, com relação às reuniões, continuarei utilizando o termo multidisciplinar, uma vez que não houve a decisão do grupo em modificá-lo.

14 Foram inseridas algumas técnicas de relaxamento e alguns dispositivos gráficos nas reuniões com os grupos, os quais não estavam previstos na proposta/estratégia Balint. 
estabeleciam com os pacientes e seus respectivos acompanhantes.

Como veremos no capítulo de Análise adiante, as enfermeiras valorizam o trabalho de Clarice e por vezes colocam nosso grupo atual como uma "continuação" daquele outro. O fato de eu ter entrado no HE como estagiário na Clínica Pediátrica e estar hierarquicamente submetido a Clarice pode ter contribuído para a produção dessas expectativas, as quais trataremos na Analise. 


\section{Método}

\subsection{Referencial teórico-metodológico}

\section{Recorte e estratégia de pensamento}

O referencial teórico-metodológico da Análise Institucional do Discurso (AID), proposto por Marlene Guirado (2000, 2004a, 2004b, 2006, 2010, Guirado \& Lerner, 2007) é a estratégia de pensamento que nos servirá de alicerce para o desenvolvimento desse trabalho. Por meio de minuciosa articulação teórica entre a psicanálise de Freud, o pensamento de Michel Foucault, a linguística de Dominique Maingueneau e a sociologia de José Augusto Guilhon Albuquerque, a autora nos convida a compreender o sujeito de maneira inédita e propõe um novo modo de realizar o que chama de analítica da subjetividade.

A AID é uma nova estratégia de pensamento concebida a partir de um cuidadoso exame de conceitos e sua articulação nas interfaces possíveis. O resultado é um novo campo de conhecimento e nova referência no modo de se pensar e se fazer psicologia. Nesse sentido, entendemos por método o conjunto de conceitos que organizam certa estratégia de pensamento. Tais conceitos parecem ser as partes mínimas as quais, articuladas, constituem "uma caixa de ferramentas" que nos serve para pensar.

Neste trabalho não consideramos a verdade produzida como única e oculta, a qual o método nos levou a encontrar. Em nosso entendimento sua produção se dá por meio de regras de procedimento determinando certos resultados os quais só podem ter ou não estatuto de verdade em função de seus princípios e pela obediência a essas regras de procedimento (Foucault, 2004). Delimitar com rigor a estratégia de pensamento implica demonstrar a forma de produção do conhecimento produzido a partir de determinado modo de pensar. Com isso, esperamos contribuir possibilitando a nossos interlocutores relativizar o que resulta deste modo de produzir conhecimento, e também para relativizar o que se configura por outros modos de pensar, não por um relativismo no qual tudo vale, mas sim por partilhar da ideia de que a verdade é produzida.

Vejamos os conceitos-chave. 


\section{Instituição}

Instituição aqui se faz compreender pelo conjunto de práticas e relações sociais que se repetem e se legitimam ao se repetirem (Guilhon Albuquerque, 1980). Essa legitimação ocorre naquilo que Guirado (2004a) chama de "o jogo de efeito de reconhecimento e desconhecimento" (p. 44). Na ação e na repetição das ações por aqueles que fazem a instituição produz-se o reconhecimento das práticas, dos papéis, das relações, enfim, da ordem estabelecida, como natural, ao mesmo tempo em que se desconhece sua relatividade, ou melhor, o seu caráter instituído, e não natural (Guirado, 2004a).

Nesse sentido, a concepção de instituição aqui utilizada implica ser ela produzida pela ação daqueles que a fazem: agentes institucionais e clientela. Agentes institucionais ocupam o lugar de quem oferece práticas (ou serviços), e a clientela é constituída por quem demanda tais práticas. A relação entre agentes e clientela, bem com entre as instituições, se dá em meio a relações de poder que produzem o fazer pelo qual determinada instituição reivindica para si o monopólio de legitimidade. A esse objeto em nome do qual a instituição se faz, e delimita seu campo de ação com outras instituições, Guilhon Albuquerque nomeia objeto institucional (Guirado, 2004a).

De posse desse conceito, poderíamos tomar a Psicologia como instituição e determinar para ela um objeto institucional, e também para a enfermagem, a medicina e assim por diante. Como veremos, a AID propõe uma abordagem que define o seu campo de trabalho, que estabelece um objeto institucional para a psicologia com a qual pretende trabalhar.

\section{Poder}

De Foucault (1990) utilizaremos o conceito de poder, compreendido como relação poder/resistência. Poder se define pela "possibilidade de ação sobre a ação de um outro" (Foucault, 1995, pp 243-244), e deve ser entendido como verbo, sendo impossível sua condição de substantivo, de algo que alguém ou algum grupo pode possuir ou estar desprovido. O poder é vetorial, ascendente e onipresente. O hegemônico é apenas a resultante de um campo de forças instável. Segundo o autor, a análise das relações de poder seria, por excelência, o analisador das relações sociais de objetivação de sujeitos (Foucault, 1995). Em 
suas próprias palavras:

Parece-me que se deve compreender o poder, primeiro, como a multiplicidade de correlações de força imanentes ao domínio onde se exercem e constitutivas de sua organização; o jogo que, através de lutas e afrontamentos incessantes as transforma, reforça, inverte; os apoios que tais correlações de força encontram umas nas outras, formando cadeias ou sistemas ou ao contrário, as defasagens e contradições que as isolam entre si; enfim as estratégias em que se originam e cujo esboço geral ou cristalização institucional toma corpo nos aparelhos estatais, na formulação da lei, nas hegemonias sociais. [...] Onipresença do poder: não porque tenha o privilégio de agrupar tudo sob sua invencível unidade, mas porque se produz a cada instante, em todos os pontos, ou melhor, em toda relação entre um ponto e outro. O poder está em toda parte; não porque englobe tudo e sim porque provém de todos os lugares. (Foucault, 1990, pp. 88-89).

O sujeito de Foucault é produzido pelas práticas de saber-poder sempre regionais e históricas. Segundo ele nos mostra em Nascimento da Clínica (Foucault, 2011), com o advento da medicina surgiu o indivíduo o qual, a partir de então pode ser estudado como tal. A partir desse acontecimento todo um campo de conhecimento, para além da medicina, pode se desenvolver. Trata-se das Ciências Humanas. Configurar os processos de objetivação do sujeito é etapa importante da pesquisa com AID, pois, tais processos são a matriz da construção da subjetividade, como veremos.

Em nossa pesquisa, por exemplo, cada participante do grupo fala a partir de um lugar institucional específico. Todas são profissionais da equipe de enfermagem, mas algumas falam da posição de enfermeira, outras, da posição de técnica ou auxiliar de enfermagem. E justamente a partir desse lugar elas se relacionam, sentem, pensam... Agem. A constituição dos lugares institucionais não depende isoladamente de cada um, mas do jogo de forças envolvendo inúmeros atores; contém uma história que precede as pessoas, história essa com a qual, por certo, irão se deparar ao ocupar esses lugares e se posicionar frente a eles, sempre com a singularidade da história de vida de cada um.

\section{Discurso}

O conceito de discurso, aqui adotado, vem da pragmática de Foucault e entendemos, assim, o discurso como ato, dispositivo que organiza posições na relação e, 
consequentemente, ocasião de exercício de poder. A Análise do Discurso de Dominique Maingueneau, partindo desse mesmo pressuposto, nos mostra que o discurso dispõe lugares entre os interlocutores, configura uma cena de enunciação e produz (n)as relações de poder. Vejamos:

Dizer que o discurso é ato dispositivo é acentuar seu caráter de dizer, em vez de acentuar o dito. Ou seja, é atentar para o que se mostra enquanto se diz: que tipo de interlocução se cria, que posição se legitima na asserção feita, que posição se atribui ao interlocutor, o jogo de expectativas criado na situação, como se respondem ou se subvertem tais expectativas, e assim por diante. Qualquer interpretação, isto é, qualquer sentido a que se chegue será uma construção que considere todo esse modo de produção, ou melhor, o contexto (em) que (se) produz a fala e suas razões (seus sentidos). (Guirado, 2000, p. 34).

Derivam dessa concepção de discurso duas linhas de análise, que também são dois operadores conceituais: cenografia e gênero de discurso. Por cenografia compreendemos a análise da cena que se constrói, que se mostra, enquanto se diz (Guirado, 2010). O trecho acima nos ensina a maneira de proceder nessa análise. Por gênero de discurso tomamos a "situação" na qual o discurso se produz. Por exemplo, numa situação de entrevista temos um entrevistado falando a um entrevistador, e temos como produto o resultado desse encontro nesse contexto. $\mathrm{O}$ resultado provavelmente será diferente se essas duas pessoas estiverem em meio a um grupo de pessoas, ou se a situação não for de entrevista, mas de consulta médica, ou de inquérito policial, e assim por diante (Guirado, 2010). Ainda sobre os gêneros de discurso, nas palavras de Guirado (2000) comentando a aula de Maingueneau:

De uma maneira mais geral, o discurso é sempre pôr em relação dois lugares. O problema dos parceiros não é somente transmitir ideias, mas é fazer reconhecer o lugar a partir do qual está falando. E fazer o outro reconhecer o lugar a partir do qual está recebendo o discurso. Mas, muitas vezes, há um conflito. Uma vez que cada um dos parceiros pretenda ser reconhecido num outro lugar. Por exemplo, se o paciente procura definir, situar o terapeuta no lugar de amigo, e o terapeuta procura manter o paciente no lugar do paciente, há conflito de reconhecimento. Isso é fundamental! Porque é unicamente a partir dos lugares que as palavras podem tomar um sentido. (p. 99)

Tal modo de conceber o discurso, acrescentado à nossa forma de compreender 
instituição, nos possibilita proceder a uma análise institucional do discurso (Guirado, 2010).

\section{Sujeito, este, dobradiça}

Esses conceitos, tomados dessa forma, são articulados com o conceito de transferência da psicanálise freudiana (Freud, 1912/2010), aqui compreendido como o conjunto de expectativas que se reeditam de modo a propor e dispor lugares, discursos e relações na cena enunciativa estabelecida entre os interlocutores (Guirado, 2000) e apenas isso. Para tanto, uma reinvenção do conceito faz-se necessária. Seria ela, antes de tudo, a "ideia de que o discurso do analista faz parte do discurso em análise e de que esse discurso pode transferir, para o contexto concreto de uma sessão, as teorias creditadas como verdade sobre o paciente, que assim antepõem à sua fala" [itálico nosso] (Guirado, 2010, p.51). Articulado aos conceitos de instituição, discurso, poder, verdade, cenografia e gênero discursivo, o que implica essa reinvenção? Nas palavras da própria autora:

Em primeiro lugar, preservar o sentido de reedição de lugares em relações que de alguma forma marcam para a pessoa o reconhecimento de si e de sua posição; mesmo que disso não se dê conta. Depois, considerar que a reedição só se faz em relações, por sua vez instituídas, em meio a procedimentos e jogos de força e de produção de verdades, que também deixam sua marca. [itálicos nosso] (GUIRADO, 2010, p.51).

Pelos grifos acima, o leitor atendo pode se remeter ao texto Nota sobre o "bloco mágico" (Freud, 1925/2011). Nele Freud descreve o inconsciente como um aparelho, sobretudo, de memória. Marcas de experiências significativas constituem a subjetividade e, além de não se anularem, elas se compõem mutuamente, modificando e reorganizando sentidos. Como concebido pela AID, tais marcas são forjadas nas e pelas relações institucionais das quais cada um de nós participa. E nossa história, sempre singular, vai sendo construída pela maneira pela qual essas relações nos afetam, nos marcam.

Com esse aparelho de memória, esse "bloco de cera" mágico, e a partir dele, nos aventuramos ao novo, construímos expectativas para esse novo, (re)editamos cenas e, principalmente, posições nas situações atuais, ou seja, transferimos. Trata-se da concepção de um sujeito que se $f a z$ sujeito no momento mesmo em que articula o contexto institucional atual com sua história singular, construída ao longo da vida pelas relações sociais 
estabelecidas com pessoas significativas e assim marcando e constituindo seu registro mnêmico.

Por fim, articulando esses conceitos-chave chegamos à configuração do sujeitodobradiça. A partir dessa metáfora, produzimos, pela Análise Institucional do Discurso, um sujeito cuja matriz são relações institucionais, sujeito forjado no calor das relações de saberpoder, sem "essência", criativo e singular na construção de si por meio das ferramentas disponíveis no campo de ação possível, subjetivando-se por meio de recuos e avanços que ora se submetem e ora resistem aos limites que o objetivam. Nas palavras de Marlene Guirado (2010):

Daí que, o campo conceitual, configurado pela e para a análise institucional do discurso, estaria na origem também do sujeito (este, dobradiça), e conduziria à possibilidade de falar em uma analítica da subjetividade. Isto porque essa análise, com o sujeito-dobradiça como seu operador, remeteria aos modos de subjetivação do sujeito institucional, sujeito da e na relação instituída/instituinte. E a subjetividade figuraria, então, como efeito de uma ordem discursiva, de um discurso-ato-dispositivo (GUIRADO, 2006). A subjetividade passaria a implicar práticas institucionais e sua análise, bem como o acionamento do sujeito-dobradiça, permitiria entrever as condições de produção do discurso e os efeitos de subjetivação. (p.137).

\section{Análise}

Diferenciamos a análise da interpretação no intuito de delinearmos a filiação teórica e a estratégia de pensamento que embasa essas práticas. A análise se filia à pragmática e à Filosofia Analítica de Austin (1962/1990), enquanto a interpretação se constitui como o fazer da hermenêutica. Na hermenêutica há um sentido oculto e é necessário, por meio de mecanismos de decifração, se chegar à verdade. A Filosofia Analítica propõe outra estratégia e se apoia em outros pressupostos. A verdade não está oculta, mas sim na superfície mesma do discurso. Ela não precisa ser descoberta por procedimentos de decifração, mas será construída pela elaboração daquilo que se pode "ver", mas, justamente por ser tão evidente, passa despercebido. O sentido ao qual se chega só se dá pela articulação do próprio discurso que se analisa, e não por verdades que se encontram fora dele, na teoria, comumente. " $o$ diferenciador é a consideração do contexto para a produção do sentido." (Guirado, 2010, p.184). Não se trata, também, de mera descrição. Como já dissemos acima, em vez de se 
atentar ao conteúdo, a análise buscará demonstrar aquilo que se mostra enquanto se diz.

Parece oportuno, aqui, darmos a palavra a Marlene Guirado: Em Analítica da Subjetividade (2010) ela diz:

\begin{abstract}
Em nome dessa marcação, reservamos para o nosso trabalho com a análise institucional do discurso, o nome, o sentido, e os procedimentos da análise (não da interpretação). Garantindo de saída que isso se faz não como reserva de mercado linguístico ou semântico, mas como um esforço de melhor caracterizar nossos procedimentos, confrontá-los com as especificidades de nossa disciplina do conhecimento e atuação profissional e, como insistimos em dizer, a elas retornar, na diferença possível, para que se continue inventando e pensando a nossa psicologia. E voltamos ao nosso ponto de partida, ou melhor, ao modo de análise da análise institucional do discurso: “conte-me como você analisa?" (p. 185).
\end{abstract}

\title{
Análise Institucional do Discurso
}

Podemos, assim, configurar o objeto institucional de nossa psicologia, aproximada à psicanálise de Freud, como sendo "as relações, mas não aquelas imediatamente observáveis, e sim tal como percebidas, imaginadas, por aqueles que concretamente as fazem" [itálico nosso] (Guirado, 2010, p. 48).

Cabe frisar que, para esse modo de pensar, ao nos relacionarmos, transferimos para situações atuais a história das posições que ocupávamos na relação com outras pessoas significativas ao longo da vida, sempre tendo por matriz relações institucionais, constituídas por relações afetivas e de poder, num jogo de expectativas marcado por essa história na articulação com o contexto atual. Ou seja, é uma concepção de relação que pressupõe certa concepção de instituição, de poder e de discurso que configura a concepção de sujeito, a do sujeito-dobradiça.

Isso posto, definimos o objetivo de nossa pesquisa como sendo o de analisar o discurso produzido em grupo com foco na relação que o profissional de enfermagem desenvolve com seu trabalho. Compreendemos por "trabalho" todo o fazer institucional desse profissional de saúde, suas práticas e suas relações sociais. 


\subsection{Procedimentos}

\section{No grupo}

A proposta dessa pesquisa nasce da prática como estagiário de psicologia no referido hospital. A equipe queixava-se de falta de um espaço de troca no qual se pudesse conversar sobre pontos difíceis na relação com o trabalho. A ideia de pensar a configuração do grupo, quando aconteceria, a periodicidade, duração e a quem se destinaria, se deu em parceria com os profissionais até o limite do que nos foi possível, dado os objetivos de nossa pesquisa. Cabe dizer que nem todas as profissionais que participaram da pesquisa ajudaram a pensar esses pontos. Foram os profissionais de nível superior, os que participavam da reunião multidisciplinar semanal, que participaram dessa fase de elaboração.

Configuramos, então, um grupo que continha enfermeiras, técnicas e auxiliares de enfermagem dos turnos da manhã e da tarde. A duração de cada encontro foi de aproximadamente uma hora, em virtude da dinâmica de trabalho na enfermaria da pediatria que impossibilitava liberar os profissionais por mais tempo. A periodicidade foi semanal, embora tenha ocorrido um espaçamento de duas semanas em virtude de um feriado entre o segundo e o terceiro encontro. Totalizamos cinco encontros para não alongar a duração do grupo com o objetivo de diminuir contingências que favorecessem a evasão. Tendo em vista a dinâmica de trabalho desses profissionais, acreditamos que seria o suficiente para a produção dessa pesquisa.

Em ato, nos propusemos a acompanhar o discurso das profissionais atentando para uma série de movimentos no discurso por meio de alguns "disparadores de escuta" (Guirado, 2010):

- O que na fala nos parecia estranho, parecia estar "deslocado" ou sem sentido aparente;

- $\quad$ O que se repetia;

- Quando se utiliza de discurso indireto livre, o "você", quando se utiliza a primeira pessoa do singular, "eu", quando se utiliza a terceira pessoa, "ele(s)", “ela(s)", e quando se utiliza a primeira pessoa do plural, "nós”, "a gente”. 
- Que relações são estabelecidas entre substantivos e adjetivos, que atributos são oferecidos a nomes, coisas e situações.

- Quais categorias gramaticais são utilizadas, como por exemplo, o uso de diminutivo, metáforas, ironia, figuras de linguagem.

- Por vezes estranhávamos e perguntávamos em tom de esclarecimento. Por vezes pontuávamos o que percebíamos como recorrente.

- $\quad$ O discurso em análise supõe aquele do lugar do analista. "é o discurso do e no dispositivo analítico que se analisa, por seus atores, em ato, em cena." (2010, p. 191).

Alguns desses procedimentos de análise estão descritos em Instituição e Relações Afetivas (Guirado, 2004b, pp. 57-58). Outros são a postura clínica pautada em um método que está mais bem desenhado na parte 5.1 A clínica redesenhada à sombra do discurso de seu livro Analítica da Subjetividade (Guirado, 2010, pp. 186-191).

Cabe ressaltar que nem sempre nos foi possível acompanhar o discurso por esses "disparadores de escuta", e também nem sempre nos foi possível analisar, em ato, o que nos era possível perceber. Isso implica dizer que a postura clínica almejada nos referenciava, de partida, mas por muitas vezes não foi possível alcançar.

\section{Na análise do material}

A proposta para a análise do material gravado e posteriormente transcrito foi a de realizar basicamente os mesmos procedimentos que propusemos para o trabalho em ato. Contudo, trata-se de um momento outro, de um discurso que não pretende a ação imediata da parte do coordenador, mesmo que por vezes a ação seja a de simplesmente deixar falar, de silenciar. Trata-se da possibilidade de perceber, fora do calor do momento, se houveram movimentos no discurso que produzíamos em grupo e, em caso positivo, que movimentos foram esses. Mais propriamente, poderemos recortar nossa análise de acordo com nosso objetivo, buscando estabelecer quais relações as profissionais de enfermagem desenvolvem com seu trabalho.

Soma-se aos procedimentos supramencionados a proposta de analisar cada encontro separadamente, buscando acompanhar o movimento próprio percebido em cada um, 
acompanhando trecho a trecho o que vai se configurando como cena. Na cena levamos em conta duas dimensões: tanto a das posições que vão se constituindo na relação entre os integrantes do grupo quanto das posições que vão se configurando na relação com os procedimentos e com os demais atores que aparecem no discurso quando se fala do trabalho. Posteriormente, organizamos essa análise prévia em temas que facilitam a apresentação dos argumentos analíticos. Nesse sentido, o leitor não acompanhará uma apresentação cronológica linear. Nossas análises farão idas e voltas ao longo dos encontros, sempre identificados no canto direito abaixo de cada citação.

\subsection{Aspectos éticos}

Cabe mencionar que um mês antes de dar início ao grupo, o pesquisador-psicólogo foi transferido para a Clínica Médica, enfermaria de adultos do Hospital-Escola, motivo pelo qual não esteve mais trabalhando diretamente com as profissionais participantes do grupo. $\mathrm{O}$ que de certa maneira contribuiu tanto com relação ao manejo no grupo quanto a questões éticas que poderiam surgir.

Apresentamos a todos os profissionais dispostos a participar dos encontros em grupo um Termo de Consentimento Livre e Esclarecido (Conforme consta em Apêndice) contendo informações sobre a necessidade de gravação das reuniões, os nossos objetivos, a possibilidade de retirarem seu consentimento a qualquer etapa da pesquisa, além do compromisso deste pesquisador em manter o sigilo dos nomes ou qualquer tipo de identificação mencionada, direta ou indiretamente. Ressaltamos que nenhuma informação será cedida a outros profissionais que não participarem dos encontros.

Informamos, ainda, que conforme a resolução n. ${ }^{\circ}$ 016/2000 do Conselho Federal de Psicologia, nos responsabilizaríamos e disporíamos de meios e competências para identificar e lidar com eventuais consequências de nosso procedimento de intervenção, ou seja, nas reuniões, por exemplo, no caso do aumento ou geração de angústia devido à narrativa de acontecimentos potencialmente traumáticos ou conflitos entre profissionais. Nesse sentido, caso fosse identificada a necessidade de continuidade do trabalho, seja em grupo ou em outra modalidade de atenção, nos disporíamos a fazê-lo ou mesmo encaminharíamos a um profissional capacitado para tal, assegurando a gratuidade do atendimento. 


\section{Análise}

A pesquisa foi construída com o material oral produzido em cinco encontros, entre o pesquisador, que será chamado de coordenador do grupo, e profissionais de uma equipe de enfermagem da clínica pediátrica de um hospital público em São Paulo. Os encontros ocorreram entre o final de agosto e início de outubro do ano de 2010.

Como se pode ver pelo sumário, nosso texto está subdividido em temas para melhor apresentar a relação que os profissionais de enfermagem desenvolvem com seu trabalho.

Iniciamos por dizer como o grupo se configurou apresentando, de partida, a relação que as profissionais estabelecem com seu ambiente de trabalho. Não se trata apenas de descrever características para "contextualizar" o leitor, mas contextualizar o discurso. Isso implica dizer do lugar ocupado por cada uma e quais relações institucionais se configuram para aí organizar um sentido para a fala das participantes.

Deste ponto passaremos ao jogo inicial de expectativas declaradas pelas profissionais para aqueles encontros e que lugar o coordenador ocupa neste momento, o que declaram esperar dele e do grupo. A análise do jogo de expectativas sob as quais o discurso foi produzido é o carro chefe da análise pragmática, pois elas organizam e dirigem o discurso.

$\mathrm{Na}$ sequência, analisaremos como se dão as relações entre as profissionais de enfermagem. Trata-se de um movimento de análise complexo, que ora atenta às posições que as profissionais ocupam nas cenas relatadas sobre o cotidiano do trabalho e ora se detém às posições que ocupam em ato ao falarem no grupo. Por esse motivo, inclusive, analisamos também a posição do coordenador nesse jogo, pois ele faz parte da cena que se monta em ato no grupo.

A relação de clientela marca o objeto em nome do qual a instituição se faz. Contudo, quando tratarmos da relação de clientela focaremos no que a mesma produz na relação que as profissionais desenvolvem com o trabalho, dado nosso objetivo com a presente pesquisa, mais do que a configuração da clientela no discurso das profissionais.

Por fim, voltaremos nossa atenção à maneira pela qual as profissionais de enfermagem se relacionam com os demais profissionais, mantendo o foco naquilo produzido na relação com o trabalho. 


\subsection{A configuração do grupo na relação com o Hospital-Escola e a Pediatria}

Como já foi mencionado em outras partes dessa dissertação, esse grupo com profissionais da equipe de enfermagem se deu em um hospital no qual o presente pesquisador foi psicólogo. Até junho do mesmo ano o pesquisador trabalhava na clínica pediátrica e após essa data, passou a ser responsável pela clínica de adultos. Portanto, durante o período em que o grupo ocorreu, apesar de não ser psicólogo da pediatria, unidade à qual pertence à equipe de enfermagem a que se refere essa pesquisa, o coordenador-psicólogo-pesquisador era visto como alguém próximo, que esteve trabalhando junto a elas durante um ano e meio.

A apresentação das participantes solicitada pelo coordenador foca um histórico profissional, tempo de profissão, onde já trabalharam, há quanto tempo trabalham no Hospital-Escola, se já passaram por outra unidade (Clínica de adultos, Cirurgia...) e como foi essa experiência. Neste grupo, portanto, dar-se a conhecer começa por mostrar-se como profissional de enfermagem a partir de seu percurso como tal. A organização dessas informações nos permitiu construir a tabela abaixo:

Tabela 1 - Tabela demonstrativa do tempo que as participantes tem de profissão, titulação, nível hierárquico no HE e se já trabalharam em outro hospital ou aparelho de saúde antes e por quanto tempo. Dados referente a 2010.

\begin{tabular}{|c|c|c|c|c|c|}
\hline Nomes & $\begin{array}{l}\text { Tempo de } \\
\text { formada }\end{array}$ & $\begin{array}{c}\text { Há quanto } \\
\text { tempo no } \\
\text { HE }\end{array}$ & $\begin{array}{c}\text { Em outro } \\
\text { hospital } \\
\text { antes? }\end{array}$ & Titulação & $\begin{array}{c}\text { Nível hierárquico } \\
\text { no HE }\end{array}$ \\
\hline Alice & 15 anos & 15 anos & Não & $\begin{array}{c}\text { Mestrado } \\
\text { (Cursando) }\end{array}$ & Enfermeira \\
\hline Duzolina & 17 anos & 16 anos & Não & $\begin{array}{l}\text { Doutorado } \\
\text { (Cursando) }\end{array}$ & $\begin{array}{c}\text { Subchefe da } \\
\text { enfermaria }\end{array}$ \\
\hline Camila & 4 Técnica & 20 anos & 5 anos & Téc. de Enf. & Téc. de Enf. \\
\hline Cátia & 5 Enfermeira & 13 anos & Não & Enfermeira & Aux. De Enf. \\
\hline Laura & 14 Aux./8 Téc. & 13 anos & Não & Téc. de Enf. & Téc. de Enf. \\
\hline Maria & 3 anos & 3 anos & Não & Téc. de Enf. & Téc. de Enf. \\
\hline Martha & 14 anos & 11 anos & 3 anos & Aux. de Enf. & Aux. De Enf. \\
\hline Rosa & 19 Aux./7 Téc. & 23 anos & Não & Téc. de Enf. & Téc. de Enf. \\
\hline
\end{tabular}


Um esclarecimento adicional se faz necessário para compreensão do quadro acima. $\mathrm{Na}$ coluna "Tempo de formadas" optou-se por colocar o tempo da última formação, a não ser no caso de Laura e Rosa, que discriminaram bem o momento da mudança. Rosa entrou no HE há vinte e três anos como atendente de enfermagem, fez o curso de auxiliar há dezenove anos e o de técnico há sete anos, tudo no próprio HE. Cátia continua com o contrato de auxiliar de enfermagem mesmo possuindo o nível superior há cinco anos. Isso se deve ao fato de a mudança de cargo se dar por via de concurso público.

De posse dessas informações, podemos dizer que se trata de um grupo heterogêneo, com profissionais de diferentes idades, em diferentes momentos da vida profissional, diferentes níveis hierárquicos e diferentes trajetórias. No percurso profissional de todas as participantes, verificamos como é significativa a presença do HE. Alice e Duzolina se formaram pela Universidade à qual o HE está ligado, portanto, estão na instituição desde o estágio. Ambas desenvolvem suas pesquisas de pós-graduação no próprio HE. Muitas delas fizeram a formação de técnica e também de auxiliar no próprio HE. Nenhuma pensa em sair do hospital.

Nos trechos abaixo podemos verificar a fidelidade mantida pelas profissionais na relação com o Hospital-Escola:

\section{C: É... Você já trabalhou em outros lugares ou só aqui?}

Duzolina: olha, sempre trabalhei aqui, mas já, assim, trabalhei dando aula... Para técnico, aula para graduação de enfermagem. Já trabalhei no Home Care duas vezes... É... E fora enfermagem, antes de me formar como enfermeira, fui auxiliar de dentista. (riso) Mas assim... Depois que comecei a trabalhar sempre aqui com mais algum lugar... Fazendo uns bicos assim, sem registro, sem nada, mas trabalhando. Com dois empregos, um parava quando estava estudando.

(Primeiro encontro)

Laura: meu nome é Laura, eu sou técnica de enfermagem, trabalho aqui no Hospital-Escola há 13 anos. Me formei há 14, como auxiliar de enfermagem. Logo no término do curso já prestei o concurso e fiquei aqui mesmo. Em 2002 eu fiz o técnico de enfermagem. Eu tive um outro vínculo empregatício que tentei conciliar dois empregos, mas para mim ficou muito difícil. A gente tem toda uma vida familiar, e filhos, e tudo, aí fica complicado ter tempo pra mais coisas... 
Martha: faz uns 14 anos que eu me formei. Trabalhei 3 anos na UTI em Osasco, no Hospital C... Aí depois eu vim para cá, para a clínica médica... onde foi meu trauma... E vou fazer 11 anos que estou na pediatria.

(...)

C: tá... você ficou quanto tempo na clínica médica?

Martha: 15 dias e ainda na marra. (...)

(Primeiro encontro)

Em todas as vinhetas selecionadas acima é possível observar, respeitada a singularidade da história de cada profissional, a regularidade em relação à fidelidade ao Hospital-Escola, em especial à Pediatria. Qualquer outro emprego, trabalho ou "bico" é de menos importância. A Pediatria do Hospital-Escola parece ser um lugar do qual não se sai. Na fala de Martha verificamos que um lugar ruim ou desagradável para se trabalhar se torna traumático, e neste caso só resta sair. O contraste entre os 15 dias na Clínica Médica - onde ficou "na marra" - e os 11 anos na Pediatria nos mostra que a profissional ali permanece trabalhando por se sentir bem:

Alice: eu entrei na UTI e depois fui para a pediatria também. UTI pediátrica.

C: e, porque você pediu...

Alice: porque eu pedi.

C: tá... E você prefere estar trabalhando na pediatria...

Alice: muito...

(Primeiro encontro)

Maria: bom, meu nome é Maria, tenho 22 anos... Estou na área faz pouco tempo, logo que me formei, aqui é o meu primeiro emprego. Foi onde que eu entrei. Não tenho muitas, assim, aventuras (ri)... De trabalho. (...)

(...)

Maria: eu me formei em 2007. Aí depois teve concurso aqui, eu prestei, passei e logo comecei a trabalhar. Não tive outros empregos. É meu primeiro emprego de tudo, (risos) da vida...

C: e você entrou direto na pediatria...

Maria: na ped [pediatria].

C: está lá desde então...

Maria: desde então.

C: tá, você sentiu vontade ir para outro lugar? 
Maria: não, não, sempre... Sempre quis trabalhar com criança e a pediatria para mim acho que é o lugar ideal. Adoro pediatria.

C: tá. Ah... Por que especificamente?

Maria: ah, porque eu gosto de criança. Gosto de lidar com criança. Eu acho que eu tenho um... Um... Acho que é... Eu me sinto mais fácil lidando com criança. Gosto muito de trabalhar com criança.

(Segundo encontro)

Neste hospital trabalha-se onde se quer, e nele o profissional se sente mais a vontade. Quando o profissional sai, é a transferência de uma clínica para outra. Na escolha da clínica para se trabalhar o que se busca é o lugar ideal para si, e isso pode ser visto com maior nitidez no discurso de Maria. Sua fidelidade se constitui na não vontade de trabalhar em outro setor. Trabalhar na pediatria, e com crianças, sua clientela, se constitui em relação de prazer na qual a profissional se sente mais à vontade e com mais vontade de trabalhar. $\mathrm{O}$ trabalho nesse lugar ideal facilita a comunicação consigo mesma.

Contudo, tal fidelização ao tipo de trabalho e sua clientela não é somente rosas:

Camila: só trabalho no Hospital-Escola... Eu trabalhei fora, mas antes. Há 25 anos atrás.

C: onde você trabalhou?

Camila: eu trabalhei no Hospital F., que faliu, né, fechou...

$\mathrm{C}$ : e sempre foi na pediatria que você trabalhou?

Camila: sempre foi na pediatria. Sempre trabalhei com crianças... Primeiro eu trabalhei no berçário e depois pediatria. Até hoje... Por isso que já estou de saco cheio, né? (ri) to sem paciência...

(Segundo encontro)

Camila, na singularidade de sua fala, apresenta o trabalho com crianças como algo que sempre fez e parece ter escolhido fazer. Paradoxalmente, o desgaste parece ser constitutivo dessa relação fiel e duradoura com tal tipo de trabalho, sempre com crianças.

\section{Expectativas iniciais e o lugar do coordenador}

Em sua fala inicial o coordenador pede para as participantes exporem suas 
expectativas e a razão de terem aceitado participar do grupo. A palavra aceitar supõe o oferecimento por parte de alguém de algo talvez nem mesmo solicitado pela outra pessoa. A ideia de constituir esse grupo surgiu em conjunto com alguns profissionais da pediatria, dentre as quais Duzolina e Alice, entusiastas da proposta. O termo aceitar, neutro a princípio, já nas apresentações iniciais colocou a questão: afinal, de quem seria a demanda por aquele grupo?

C: vou pedir também para vocês dizerem por que vocês aceitaram participar do grupo e quais são as expectativas que vocês têm para os encontros (...).

Duzolina: ah, eu aceitei para colaborar com você (ri), na sua tese, e eu acho que é uma oportunidade da gente estar falando e espero que a gente tenha alguma... Um crescimento, que saia alguma coisa produtiva, né? Que a gente, que você possa... Não sei se vai sair só da gente ou se você vai trazer alguma coisa para a gente, para a gente melhorar, alguma coisa assim... né? Como profissional, no atendimento, não sei...

(Primeiro encontro)

O que acontecerá no grupo ainda é algo que não se pode prever, ao mesmo tempo em que esse grupo é tomado como oportunidade. Oportunidade de crescimento, de melhora como profissional... Ainda não se sabe... Mas também é oportunidade de colaborar com um colega que, como a própria participante, está escrevendo sua tese ${ }^{15}$. Sigamos as expectativas de Rosa:

Rosa: E eu também estou aqui para colaborar com você e... Não tenho expectativa assim, vou ver o que vai acontecer ainda, estar falando, respondendo o que for necessário...

(Primeiro encontro)

As profissionais sugerem que o coordenador traga ajuda. Contudo, há certa incerteza em relação a essa ajuda. Já a ajuda delas ao coordenador é certa.

De modo geral, no primeiro encontro, as profissionais afirmaram ter aceitado participar do grupo para ajudar o coordenador na pesquisa. Podemos perceber, entretanto, certas nuances de expectativas abrindo outras possibilidades para o grupo. Sigamos o discurso de Alice:

Alice: E o que eu espero dos encontros? Também foi para colaborar com você, no seu

15 Logo antes, Duzolina refere estar fazendo seu doutorado: "Nesse período fiz especialização em administração, fiz estomaterapia e fiz... mestrado em administração de enfermagem e agora estou fazendo doutorado..." 
mestrado, e eu acho que vão surgindo assuntos durante o decorrer do tempo. Acho que a situação que estiver acontecendo no momento lá embaixo a gente vai acabar trazendo para cá... Acho que é isso.

C: então um pouco da expectativa é poder estar conversando sobre acontecimentos bem contemporâneos assim... Do dia a dia...

Alice: uhum...

C: tá...

Alice: provavelmente é o que vai surgir, né. E o primeiro assunto eu já te digo que vai ser a escala mensal (ri)... Que é o que vai estar rolando agora, né.

(Primeiro encontro)

Não entra em questão se o coordenador poderá ou não ajudar. Conversar sobre o cotidiano parece ser para Alice, inevitável. A palavra surgir sugere que o que fosse acontecer nos encontros se daria de forma quase que independente, como algo que pudesse prescindir dela, do coordenador e dos outros participantes.

Continuemos com a apresentação de Laura, na qual aparecem nítidas demanda, expectativa e prazer:

Laura: Eu gosto de participar dos eventos que tem aqui no hospital, das palestras, dos fóruns, a gente se esforça bastante para conseguir participar, que eu acho que isso enriquece você como profissional, te dá oportunidades... E é isso.

C: ahm, e aí por que você aceitou participar do grupo?

Laura: então... Eu sempre gosto de participar desses grupos assim, acho que te ajuda a ver as coisas de uma outra maneira, que às vezes você fica tão focada, fechada ali naquela sua rotina ali da, da pediatria, né, das coisas da unidade, que você fica com foco muito centrada em uma coisa e vai acarretando uma série de stress, né, você fica insatisfeito com muita coisa. Eu acho que essa é uma oportunidade de você ampliar a sua visão das coisas, e ver que esses pequenos detalhes do dia a dia fazem parte da rotina e... você vai ter que superar. Acho que o grupo vai ajudar um pouco nisso.

C: você tinha participado do outro?

Laura: a Clarice fez, né, um grupo. Eu comecei a participar, aí depois não deu, porque eu mudei o horário do plantão, aí... Os encontros aconteciam à tarde e não dava tempo de eu participar.

(Primeiro encontro)

A rotina contém em si um efeito danoso, que resulta em uma "série de stress". A saída 
é sair dela, como vimos com Martha na Clinica Médica. Nesse sentido, o grupo, como possibilidade de saída junto aos outros "eventos”, já cumpriria tal função. Mas Laura espera um pouco mais, espera conseguir ajuda para "superar" essas dificuldades do cotidiano. Tais expectativas derivam em boa parte da experiência anterior com outra psicóloga que também realizara um grupo com as enfermeiras da pediatria em outro momento. Neste ponto vale chamar a atenção para a maneira de Laura apresentar suas expectativas, ela antecipa o que vai acontecer, como se tivesse certa previsão de quais resultados seriam produzidos ao final do grupo.

Martha foi a última a se apresentar. Ela chegou atrasada neste primeiro encontro e se apresentou de um modo que destoa das demais participantes. Como se tivesse perdido o tom das demais colegas, começa falando de modo entrecortado e meio perdido, como ela mesma diz:

C: tudo bom, Martha? (...)

Martha: estou mais perdida do que tudo (ri)...

C: não, tudo bem (...) A gente está fazendo uma rodada de apresentação. (...) E por que aceitaram participar do grupo e as expectativas para esses encontros...

Martha: bom, na verdade eu vim mais por curiosidade, porque eu nunca participei desse grupo, né. Então mais para esclarecimento mesmo.

C: Uhum... Certo... Fala um pouquinho quanto tempo faz que você se formou... Você é técnica? (...)

C: (...) E você tem algumas expectativas em relação ao grupo, o que você acha que seria bacana a gente estar conversando aqui...

Martha: ah, eu acho que... Expectativa eu tenho. Porque na verdade eu não... Eu tenho uma certa dificuldade também... Para participar desses grupos assim... Então, agora eu estou, assim, aos poucos eu estou querendo mudar um pouquinho.

C: tá, como assim dificuldade?

Martha: hum... É que eu sou assim, eu acho que eu sou muito fechada pra mim mesmo, você entendeu?

C: tá...

Martha: não sou de ficar falando muito, conversando muito... Perguntando, muito menos. Então, aí eu resolvi assim... Começar com um grupo para ver se eu mudo um pouco...

(Primeiro encontro)

A profissional refere motivos pessoais para a procura do grupo. O que espera é 
conseguir mudar. Tem a expectativa de que o grupo a ajude a não ser tão fechada em si mesma. Sugere que a participação já seria, inclusive, ocasião do exercício de se colocar, de se abrir, de mudar. Buscar o grupo já é mudar, colocar em movimento a tarefa que visa o objetivo da procura. Contudo, a consolidação dessa mudança ainda é incerta.

Ao mesmo tempo a aposta de que será "bom" se liga, de modo geral, à experiência anterior com outro grupo coordenado pela psicóloga Clarice $^{16}$ :

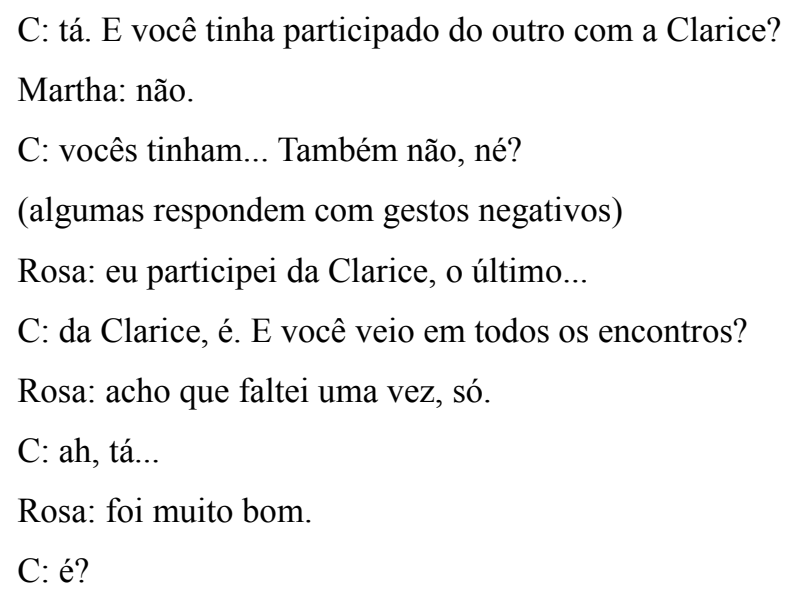

(Primeiro encontro)

Observamos, por parte das profissionais, a expectativa de que este grupo produza resultados parecidos com os que foram produzidos pelo grupo realizado por outro profissional da psicologia. Na fala de Rosa é possível perceber que para ela não há diferenciação. Ela refere estar "de novo". Ela participou do último da Clarice, demonstrando ter havido outros, ou pelo menos mais de um. Rosa, participante assídua, gostou e "voltou" na expectativa de ter mais do mesmo. Já no caso de Martha, é o comentário das colegas sobre esse "outro" grupo que organiza suas expectativas e a faz acreditar que poderia mesmo ser boa experiência.

Camila, Cátia e Maria não estiveram presentes no primeiro encontro. O coordenador, em virtude da análise do primeiro encontro, trocou o termo aceitaram por resolveram ao 
solicitar as expectativas das profissionais. Das três participantes, apenas Maria comparecera desde o início do segundo encontro. Sua expectativa também é de melhorar o trabalho, o "grupo", e também trocar informações, contudo não refere auxílio ao coordenador como motivo para sua participação.

Maria: [...] O que estou esperando do grupo é... Acho que melhorar né, o nosso trabalho. A gente ter informações dos outros profissionais, saber o que cada um passa, como que lida com as situações, e tá... Uma forma de melhorar.

(Segundo encontro)

Cátia e Camila chegaram durante esse segundo encontro. O coordenador optou por dar continuidade ao que vinha sendo tratado e deixou a apresentação das duas para o final. Camila inicia sua apresentação sem ter ouvido as demais colegas que, por mais que demonstrem querer ouvi-la, cochicham acerca de outros assuntos. No mesmo clima de cumprir protocolo, Cátia também se apresenta:

C: certo... E por que você resolveu vir para participar do grupo?

Camila: ah! Para desabafar, né? Não é para uma conversa, um desabafo? Era para desabafar, né...

$\mathrm{C}$ : tem alguma coisa, alguma expectativa... Além do que a gente conversou?

Camila: não... É bom que você desabafa, põe tudo... Põe tudo suas... Suas ofensas não pode falar, você consegue falar... Você vê todo mundo falando, aí você acaba emendando e falando junto também... (risos)

C: tá... Está certo. E você Cátia?

(...)

Cátia: justamente por isso mesmo: para a gente conversar... Porque a gente conversa ali...

(...)

Cátia: não sabe o que o outro pensa...

(Segundo encontro)

Para Cátia o grupo é um lugar de encontro, de saber o que o outro pensa, de ouvir. Para Camila é um lugar de desabafo, de falar o que não se consegue... O fato de outras pessoas também estarem "desabafando" parece abrir caminho ao que ela gostaria de dizer.

As expectativas de melhora são ora dirigidas ao coordenador, ora ao grupo, e há 
incertezas quanto à possibilidade de ajuda, em especial a advinda do coordenador, mas também a proveniente do grupo. A experiência prévia com outro profissional de psicologia transfere expectativas para o grupo com o qual trabalhamos nesta pesquisa, e as faz também apostar na possibilidade da ajuda esperada.

Nesse sentido o lugar atribuído ao coordenador por meio das expectativas iniciais é o de alguém que talvez não possa ajudá-las. Um coordenador sem legitimidade prévia. A credibilidade, quando aparece, advém de expectativas geradas por outra experiência, com outro profissional. Ao mesmo tempo o coordenador é alguém que está sendo, indubitavelmente, ajudado.

Em meio a essa tensão inicial, as expectativas de troca de informações, falar e ouvir abrem novas perspectivas que prescindem do binômio ajudar/ não ajudar.

Cabe assinalar que esse grupo do qual trata nossa pesquisa se constitui com diferenças significativas em relação ao outro realizado por Clarice. Desde os objetivos do trabalho, a configuração dos participantes (pertencentes a diferentes níveis hierárquicos e de plantões distintos), a estratégia de pensamento adotada para análise e condução do grupo, até o fato de se tratar de pesquisa de mestrado e tudo o que isso envolve.

\subsection{As profissionais de enfermagem, o coordenador e o grupo}

Mostraremos aqui quase sempre diálogos nos quais as profissionais falam acerca da montagem da escala mensal de trabalho. De fato, seu modo de falar desse tema nos informa das relações de poder entre as profissionais da equipe de enfermagem da clínica pediátrica do HE.

A "Escala", segundo elas, é o maior problema a ser enfrentado para a melhoria nas condições de trabalho. A importância do tema fora anunciada por Alice já no primeiro encontro ao dizer das expectativas "E o primeiro assunto eu já te digo que vai ser a escala mensal (ri)... que é o que vai estar rolando agora, né”. Foi no terceiro encontro, contudo, que o grupo iniciou a discussão e reflexão a seu respeito. Boa parte do quarto e quinto encontros também foram dedicadas a esse assunto. Vejamos como nos é apresentado o tema:

Duzolina: que existe um assunto polêmico em todos os plantões, para todos os níveis, existe.

(...) 
Alice: O estresse na última semana do mês...

Duzolina: O estresse na hora da confecção... Quem vai tirar folga final de semana, quem troca, quem não troca...

(...)

Laura: eu fico até com dó de quem vai fechar a escala... Porque a orelha queima, né...

Duzolina: você é xingado! Excomungado! A sua mãe! A sua avó também! A sua família, todas as gerações, se você não atende ao pedido... E aí vai... Isso estou falando de técnico e enfermeiro, tá...

(Terceiro encontro)

Como as próprias enfermeiras anunciam, trata-se de um "problema" na esfera política da organização do trabalho, em especial na maneira de se relacionarem.

De saída podemos observar na fala de Duzolina a existência da divisão em dois grupos, o de técnico e o de enfermeiro. Vamos a eles...

\section{As enfermeiras de nível superior, suas técnicas e suas auxiliares}

Por mais que haja três categorias na equipe de enfermagem, podemos verificar dois grupos. O das enfermeiras de nível superior e o das técnicas.

C: tá, e nesses fóruns a ideia é o que?

Duzolina: apresentação de trabalho científico, que é desenvolvido na unidade, por eles. Os técnicos que fazem e a enfermeira orienta, direciona, mas quem desenvolve todo o trabalho é a equipe técnica.

(Primeiro encontro)

$\mathrm{Na}$ separação entre os que ensinam e os que executam o trabalho científico, a enfermeira é quem orienta e direciona. Aos técnicos cabe desenvolver o trabalho.

Como vimos no capítulo 2.2 A equipe de enfermagem, as enfermeiras cumprem o papel de chefes de equipe. Cada enfermeira pode chefiar de seis a oito técnicos (entre técnicos e auxiliares).

Quando o assunto é a montagem da escala de trabalho, também se evidenciam diferenças significativas: 
Duzolina: e a escala de enfermeira, meu Deus do céu! Meu Deus do céu! (...)

(...)

Duzolina: (...) É muito mais fácil você fazer a escala de técnico, que são dezesseis...

Alice: do que fazer a escala do 'talibã'.

Duzolina: do que fazer a escala de enfermeira.

(...)

Duzolina: porque com técnico você consegue... Tem mais opções para você trocar final de semana, plantão, 'parará'... Do que enfermeira que não tem muita opção. Então, as enfermeiras quase que se matam.

Alice: acontece que...

Duzolina: Essa é a grande verdade. (ri)

(Terceiro encontro)

O número reduzido de profissionais, no discurso delas, é a causa principal do "problema". Mas não se trata da queixa de falta de enfermeiros. O que temos é um grupo de enfermeiras que precisa decidir por si, e o modo de decisão é bélico.

Com as técnicas o funcionamento parece ser outro. Por exemplo, na conversa de Alice e Laura:

Alice: Acontece que sempre são as mesmas pessoas que cobrem as mesmas coisas. E outras pessoas dizem "não, eu não vou cobrir porque isso, porque aquilo, porque aquilo outro", e sempre sobra para a mesma pessoa... Sabe?

C: uhum...

Alice: só que assim...

Laura: eu acho fácil. É só não dar o direito da pessoa de... De retrucar...

Alice: só que, você sabe que, só que não é assim que funciona...

Laura: mas é assim que funciona para a gente!

Alice: Para vocês é uma coisa.

Laura: Você vai fazer e ponto.

Alice: Eu estou falando que a gente é o próprio 'talibã'... Vocês não estão achando graça...

C: mas como assim 'talibã'?

Alice: é tipo... Guerrilheiro mesmo, terrorista...

(...)

Alice: tipo... "ema, ema, ema, cada um com seus problemas", "eu não vou fazer, faça você!"“.

(Terceiro encontro) 
Para os técnicos, o que funciona é a verticalidade da ordem advinda de um superior, sem o "direito de retrucar" - ou sem a previsão de negociação. No grupo das enfermeiras, esse modo de funcionar, alerta Alice, não funciona. O que temos, então, é uma guerrilha. Uma disputa corpo a corpo, que parece não cumprir regras e nem ter limites, sem solidariedade nem compaixão ${ }^{17}$. Um clima de matar ou morrer. Salve-se quem puder... O grupo de enfermeiras tem natural tendência terrorista no discurso de Alice. A ação terrorista caminha no sentido de acirrar os conflitos, e não no de solucioná-los.

Já no início desse tópico Duzolina aparece anunciando que o assunto é "polêmico para todos os plantões em todos os níveis". Nesta toada, muitas vezes as profissionais falavam de forma genérica de um problema específico a um grupo. Por vezes as diferenciações entre técnicas e enfermeiras ficavam mais evidentes, mas em geral ocorria a não especificação.

Quanto à polêmica em relação à escala, ela se dá, em especial, no grupo de enfermeiras:

$\mathrm{C}:(\ldots)$ como que as reuniões são feitas?

(...)

Duzolina: E quando é de enfermeiro, ela [Anely, chefe das enfermeiras] faz... Começa ás duas horas, ela começa dando todos os recados, novidades, mudanças, não sei o que... Barará, barará... E por último fica o problema da escala para a gente resolver...

Alice: deixa o povo se matar...

C: sempre fica por último...

Duzolina: sempre fica por último.

C: tá...

Alice: que acho que, no fundo no fundo, ela sabe que nunca vai resolver.

C: é... Parece...

Alice: porque assim, precisa dar os recados, ela tem que dar os recados...

Duzolina: falar de mudança... De rotina, barará, barará... E por último fica um assunto polêmico... Que ela tenta intermediar entre as enfermeiras.

(Terceiro encontro)

17 No início do quarto encontro, se referindo a este tema Alice diz: "você pode se 'estrebuchar' no chão, que nem uma lagartixa na areia quente que você não adianta, que você não recebe. E sempre as mesmas pessoas recebem." 
A reunião de enfermeiros funciona tal qual as outras, até surgir o "problema da escala", que fica por último. A chefe sai de cena nesse momento. Para Duzolina, ela passa à função de intermediadora. Para Alice, a intermediação é um abandono ${ }^{18}$.

No trecho abaixo Duzolina busca esclarecer qual é o problema por meio de um "exemplo bem claro":

Duzolina: um exemplo... Um exemplo bem claro, já que vocês estão aqui... A próxima escala tem feriado no dia 12 de outubro.

(...)

Duzolina: Tem enfermeira que folgou o feriado passado... Teria que se revezar. Um feriado trabalha uma equipe, outro trabalha a outra. Tem que se revezar, e às vezes não dá. Mas, chega uma enfermeira, bota folga na escala, lá, quatro dias do feriado, e fala assim "eu vou folgar no feriado! Por bem ou por mal... Se me der, muito bem. Quero ver neguinho apagar as minhas folgas na escala, e se apagar, eu vou folgar de qualquer jeito, porque eu vou pegar. licença". Você é obrigada a escutar uma coisa dessas. Você fica, eu fico emputecida! Desculpa falar, mas eu fico...

(...)

Duzolina: é... Porque não é assim que funciona! A gente tem que conversar...

Laura: ah, mas aí coloca plantão para a pessoa, lá.

Alice: teoricamente a gente é adulto!

Duzolina: aí você põe plantão, a neguinha vem com atestado médico, já verbalizou que vem com atestado médico!

Alice: falou.

Duzolina: O que você faz?

Laura: Ué, deixa vir então...

Duzolina: você como chefe...

(Terceiro encontro)

A solução apresentada por Laura não funciona para as enfermeiras. Laura é técnica, a solução que ela apresenta "funciona" para o grupo de técnicas, o que aponta para lógicas relacionais distintas.

Um dos pontos contidos no "exemplo bem claro" de Duzolina é a ameaça da enfermeira dirigida à sua chefe e ao funcionamento da enfermaria, e quem se encontra encurralado neste momento é a chefia.

18 Mais a frente falaremos especificamente como esse modo de compreender diz das posições ocupadas por essas duas profissionais. 
Resoluções rápidas, verticais e eficientes não funcionam para as enfermeiras. Contudo, a democracia aparece também como um problema. Ela também apresenta "problemas" no seu funcionamento. Como vimos, a lógica das discussões respeita a regra de sair sempre por cima, o que Alice denomina terrorismo. No terrorismo, o que se produz não é a resolução de conflitos, mas sim o seu acirramento, como já mencionamos.

\section{Duzolina e Alice ou sobre incêndios e terrorismo}

Duzolina e Alice são as duas únicas enfermeiras que participaram do grupo. Possuem quase o mesmo tempo de profissão. São amigas, para além do coleguismo profissional:

Duzolina: (...) Eu e a Alice temos mais ou menos o mesmo... Tempo de casa.

Alice: três meses de diferença.

Duzolina: Uma diferença de três meses. E...

Alice: A gente já pegou muito...

Duzolina: Então a Alice sempre está lá pra... Pra me acalmar, né. (riso).

(Primeiro encontro)

Como já vimos no subitem "Configuração do grupo", ambas estão cursando a pósgraduação. As duas são chefe de equipe, mas Duzolina é subchefe da enfermaria, ou seja, das enfermeiras também.

Tal proximidade guarda uma diferença de posição que vai além da questão hierárquica, mas que é investida (vestida por dentro) por ela. Duzolina e Alice parecem representar de maneira emblemática a relação poder/resistência na instituição, segundo nossa análise. Nessa polarização, Alice é quem fica do lado da resistência. Contudo, vale a pena pontuar que no extrato acima Duzolina refere que Alice sempre está lá para acalmá-la. O que veremos nesse tópico, entretanto, é que as funções são justamente invertidas no dia a dia. Comecemos apresentando a maneira como Duzolina se coloca: "o discurso da chefe":

C: Am... Você disse que participou de palestras e não participou de fórum... Como assim? Rosa: assim... Eu...

Duzolina: é que aqui no hospital tem o fórum de enfermagem, que acontece todo ano... Ou 
cada dois anos, né?

Alice: cada dois anos.

Rosa: acho que teve uns três até agora, né...

Alice: dois. Acho que foi dois.

Duzolina: é, por aí... Dois... Não sei... E aí acaba que você, ela não participa, né? Mas vai ter um outro no ano que vem, você vai participar...

(risadas)

C: tá, e nesses fóruns a ideia é o que?

Duzolina: apresentação de trabalho científico, que é desenvolvido na unidade, por eles. Os técnicos que fazem e a enfermeira orienta, direciona, mas quem desenvolve todo o trabalho é a equipe técnica.

C: você nunca participou, por quê?

Rosa: por disponibilidade de tempo assim,

(Primeiro encontro)

Duzolina responde por Rosa quando esta vacila e, nessa ação, se responsabiliza pela resposta da técnica de enfermagem e a intima a participar. As risadas parecem cumprir um importante papel atenuante da rispidez da ordem dada. Duzolina exerce sua função de chefe também no grupo que montamos para esta pesquisa e, ao fazê-lo, nos dá indícios de como faz no trabalho na enfermaria. Apenas quando o coordenador dirige sua pergunta a Rosa é que a técnica de enfermagem dá a conhecer os motivos de não ter participado.

Num outro momento Camila nos diz de como ela entende a relação com a chefe. $\mathrm{O}$ coordenador está se referindo a Duzolina que havia faltado naquele encontro:

C: (...) aquela hora [terceiro encontro] parecia que tinha solução. Na semana anterior parecia que eram problemas sem solução, tipo “é muito difícil, é muito difícil”, e naquela hora parecia que não, era fácil de resolver. E aí os problemas fáceis de resolver a gente estava passando, né. (...) E... nessa hora, ficou presente também que em alguns momentos fica muito personalizado também quem resolve...

Camila: porque ela é líder! Ela é líder. Então se ela falar 'não', é não. Quem sou eu para falar com ela "não, é sim!"?

Rosa: ela que faz a nossa escala, né...

Camila: não, não é nem a escala que ele está falando. Ele está falando dos problemas com os pacientes, não é isso, que você está falando?

C: isso, com as mães...

Camila: Ela vai lá fala “ah...” põe regra e pronto. Quem vai enfrentar ela? Ninguém! 
C: mas isso que a Rosa está falando eu acho que tem a ver também, né? Porque ela é líder também na hora de montar a escala...

Camila: a escala também... é...

(Quarto encontro)

Essa "líder" que "põe regra" o faz tanto em relação à clientela quanto aos agentes institucionais. Para Camila, ela é alguém que não se pode enfrentar. É como se a possibilidade de resistência estivesse anulada. Como se a hierarquia fosse soberana. Para o coordenador, Duzolina se constitui na personalização de quem resolve naquele grupo. Mais adiante trataremos do coordenador.

Neste hospital os líderes são escolhidos de cima para baixo. E o maior nível hierárquico é definido por outra instância que não o próprio Hospital-Escola. Vejamos como surge essa informação, observando a fala de Alice:

C: e como que é decidido quem vai ser o chefe de vocês?

Camila: como assim, o chefe...

Alice: acho que é o departamento de enfermagem que decide...

$\mathrm{C}$ : o departamento que escolhe...

Alice: exato.

C: e quem escolhe a chefe do departamento de enfermagem é o superintendente?

Alice: a 'chefe-mor'?

C: é.

Alice: que eu falo que é a 'rainha-mãe'... A 'rainha-mãe' é escolhida da seguinte forma: sempre é uma professora da Escola, acho que tem que ser professor titular... Sempre a cada 4 anos é uma delas.

C: tá...

Alice: até o ano passado era a professora Verônica, entrou esse ano a professora Franciely. E aí a Escola indica quem vai ser (...)

(Quarto encontro)

Ao se falar de nomeações, o coordenador busca saber, pela hierarquia, quem nomeia a "chefe-mor". Por ironia, quem a nomeia é Alice. O “acho" inicial lança a incerteza como isca, a partir da qual se segue uma série de informações com ares de exatidão. Ao tratar ironicamente dessa hierarquia, Alice se autoriza a resistir a ela, a desqualificá-la em certa medida. Na própria maneira de se referir à hierarquia, Alice a subverte. Sigamos mais um 
trecho para acompanharmos a maneira de Alice se posicionar e observemos a reação do grupo:

C: (...) queria que vocês falassem um pouco se vocês pensaram alguma coisa da semana passada para essa... (...)

Alice: na verdade eu não pensei em nada, não.

(...)

Rosa: o assunto era sobre?

Alice: ah, escala, né...

(...)

Camila: o que vocês falaram?

Alice: eu preferia não pensar.

C: é?

Alice: uhum...

C: por que Alice?

Alice: Ai, porque não quero me chatear, Ronaldo. (...) pensar nisso pra me chatear? Não!

Camila: o que vocês falaram sobre a escala?

Alice: imagina!

Rosa: descontentamento assim de... De pedir folga e não ter a folga o dia que quer... Ou...

Alice: sempre as mesmas pessoas ganham sempre as mesmas coisas e outras não ganhando...

Mas semana que vem vai começar a tortura, que ela vai começar a mexer... (...) aí vai começar... Vai começar a briga. Já estou até vendo... É um Talibã, que eu te falei. (...)

(...)

Camila: a escala é sempre a mesma coisa. É sempre as mesmas pessoas que ganham... Você pode pedir lá, bolar... Mas...

Alice: você pode se 'estrebuchar' no chão, que nem uma lagartixa na areia quente que você não adianta, que você não recebe. E sempre as mesmas pessoas recebem.

(Quarto encontro)

Apesar de dizer que não pensou em nada e que nem quer pensar, Alice é a que mais se coloca. Inclusive, é mesmo desse modo que ela inaugura o assunto. É dizendo que não quer falar e nem pensar que Alice fala sobre o que a "chateia". Como podemos verificar ao longo de todos os cinco encontros, Alice é a que mais se incomoda com a injustiça de serem "sempre as mesmas pessoas que recebem". A resistência a esse modo de se montar a escala toma a forma de reclamações e de brigas mensais, até certo ponto previsíveis. Apesar de toda a tensão e atrito, parece ser um consenso entre as profissionais que participaram desse quarto 
encontro que "sempre as mesmas pessoas ganham sempre as mesmas coisas".

A chefe aparece como quem tem o poder de decidir quem deve ganhar ou não. Ao mesmo tempo, a "briga" se dá entre os profissionais e não apenas com a chefe. Ao final de todo o estresse, a sensação de que nada muda. Pensar ou falar sobre o assunto poderia trazer apenas "chateação", "descontentamento".

Mais a frente Alice fala de um "medo". Sigamo-la:

Alice: eu tenho medo assim, juro para você, de um dia acontecer que nem aconteceu naquele "Um dia de fúria" no filme... Você viu aquele filme?

(risadas)

Laura: com o Michael Douglas, né?

Alice: Michael Douglas sai quebrando tudo... Porque assim, as coisas vão subindo, subindo...

Que nem panela em ebulição, que está fervendo água, vai subindo, subindo, subindo, e aí? Tem gente que perdeu o respeito...

Laura: Porque tem que ter uma válvula de escape ali, né, assim...

Alice: tem gente que perdeu o respeito!

Laura: Tem gente que busca fora uma válvula de escape assim... Vai fazer uma academia, faz uma ioga... Faz uma... A maioria não tem, gente! Sai daqui, vai para casa e continua trabalhando, tem dois empregos... Então vira uma coisa que vai...

(Quarto encontro)

Alice fala de situação da qual parece não haver saída. Para Laura, a saída é sair... Já havíamos mostrado isso quando ela fala das expectativas iniciais. Para Alice, o descontrole e a intolerância são anunciados como a resultante possível de um conflito no qual as pessoas perderam o respeito.

Não são poucas as vezes em que Alice fala em metáforas e hipérboles. Ao seu modo peculiar, mais do que anunciadora dos perigos da "panela em ebulição" ela parece ocupar o lugar de quem ateia fogo nessa panela.

Se o lugar configurado por/ para Alice é o de incendiária, por certo o lugar construído por/para Duzolina é o de bombeiro:

Maria: (...) Lógico que acontece de ter pessoas mais privilegiadas, mas acontece também da pessoa não pedir e depois querer reclamar de uma coisa que não pediu.

C: e tem pessoas mais privilegiadas, então...

Maria: ah, a gente acha que às vezes sim... (ri)... 


\section{Duzolina: eu não vejo por esse lado... De privilégio}

Maria: não sei se é privilegiada, mas...

Duzolina: Eu vejo assim: a pessoa (...) sempre pede os feriados, e aí quando você vai fazer a escala você não está... Na cabeça com a escala anterior... E nem as outras...

(...)

Duzolina: (...) quando eu vou fazer a escala... (...) eu vou dar preferência para as pessoas que pediram o feriado... Que bolaram. (...) Aí, por exemplo, se acontece de várias pessoas pedirem o feriado, aí para desempatar, aí que você se atenta de pegar a escala anterior e a outra ver quem já trabalhou... (...) Mas só quando dá muita briga, porque senão... Eu não me importo em olhar a escala anterior.

Maria: e vai um pouco da consciência da pessoa. (...) eu penso dessa forma. (...) "ah, trabalhei o outro, poderia folgar esse", mas tem pessoas que não pensam dessa forma, "ah, folguei no outro, vou folgar esse, vou folgar no próximo... vou folgar o outro", e você tem que ter um pouco de consciência (...). Quando você entra no hospital você sabe que tem que trabalhar feriado, sábado, domingo... O que for... (...)

(Quinto encontro)

Ao surgir a suspeita de que haveria pessoas sendo privilegiadas, Duzolina logo interfere e "apaga" o burburinho (ou o fogo). Ela mesma diz, inclusive, que interfere na escala "bolada" pelas profissionais só "quando dá muita briga". A fala de Maria, na sequencia, vem para marcar que de fato a suspeita em torno do "privilégio" se pulveriza. No lugar, surge a retomada da "consciência" de cada um como tarefa importante na "resolução" do problema da escala.

Da mesma forma, o lugar configurado por/ para Anely, a chefe da enfermaria da pediatria, é o mesmo de Duzolina, a subchefe. Parece ser essa uma característica da chefia:

$\mathrm{C}:(\ldots)$ como que as reuniões são feitas?

Alice: reunião de condomínio!

C: é marcado periodicamente?

Alice: teoricamente era para ser, né.

Duzolina: A Anely acho que está [inaudível] marca reunião de enfermeiras quando tem bastante recado para dar... Várias mudanças estão ocorrendo, ou quando está um caos na Unidade, está tudo 'zoado', daí ela marca com todos os plantões...

Alice: Pra dar o 'craw'.

Laura: (ri)

C: mas aí é todos os plantões no mesmo horário... 
Duzolina: não. Marca o plantão da manhã em um horário, marca com o plantão da tarde... Plantão noturno de um, ala par, e plantão noturno impar... E marca com as enfermeiras e marca com os técnicos.

C: também são separados...

Duzolina: são separados. Reuniões separadas, de técnico e enfermeiro...

Laura: mas ela faz reunião junto também, com as enfermeiras de todos os plantões, né...

Duzolina: é... Aí... Daí ela... Ela sempre reúne...

C: como? Desculpa...

Laura: ela faz reunião com todas as enfermeiras de todos os plantões junto...

C: todas as enfermeiras... Entre técnicos...

Laura: de todos os plantões... Não, só enfermeiras...

Duzolina: não. As reuniões de enfermeiras são só de enfermeiras...

C: tá.

Duzolina: aí às vezes ela faz reunião de enfermeira com técnico, para dar a mudança de alguma rotina... Nãnãnã, nãnãnã... Falar que está tudo 'zoado'... Uma reunião rápida.

C: tá...

Duzolina: E às vezes ela faz uma reunião oficial, para fazer plantão. Reunião com os técnicos da manhã, mais a enfermeira da manhã. Plantão de reunião com os técnicos, mais a enfermeira da tarde. E assim, cada técnico, cada equipe ela faz num plantão...

C: uhum... Tá...

Duzolina: E quando é de enfermeiro, ela faz... Começa ás duas horas, ela começa dando todos os recados, novidades, mudanças, não sei o que... Barará, barará... E por último fica o problema da escala para a gente resolver...

Alice: deixa o povo se matar...

C: sempre fica por último...

Duzolina: sempre fica por último.

(...)

Duzolina: (...) e por último fica um assunto polêmico... Que ela tenta intermediar entre as enfermeiras.

(Terceiro encontro)

C: uhum... E as reuniões, pelo que eu entendi, são marcadas só...

Camila: são raras. Só para levar bronca...

Alice: quando está pegando fogo...

(Quarto encontro)

O trecho acima nos mostra bom exemplo de Alice e Duzolina em ação. Uma incendiando e a outra apagando o fogo. É possível notar que nas três vezes em que Alice se 
pronuncia, no primeiro extrato, ela usa de ironia e metáfora, responde sem responder, e provoca. Duzolina, ao contrário, passa tanta informação para explicar sobre as reuniões que a conclusão possível é a de que a chefe as marca de acordo com sua própria necessidade. Necessidade essa que aparece em torno de apagar incêndios: organizar, dar bronca, informar novidades e mudanças. A pauta, a organização e a periodicidade são circunstanciais, de acordo com os objetivos da chefia para cada situação.

Quando o assunto é a escala de enfermeiros, Anely se coloca num outro lugar. Para Duzolina ela se transforma em mediadora, busca um "acordo de paz". Para Alice ela é "desertora", e num segundo momento parece reconhecer a função de "apagar incêndios". No meio da guerrilha e de toda a fumaça, encontramos Alice tocando o terror.

De anunciadora do terrorismo a terrorista ${ }^{19}$, o movimento de Alice.

No ultimo encontro Alice faltou, sigamos como se referem a ela:

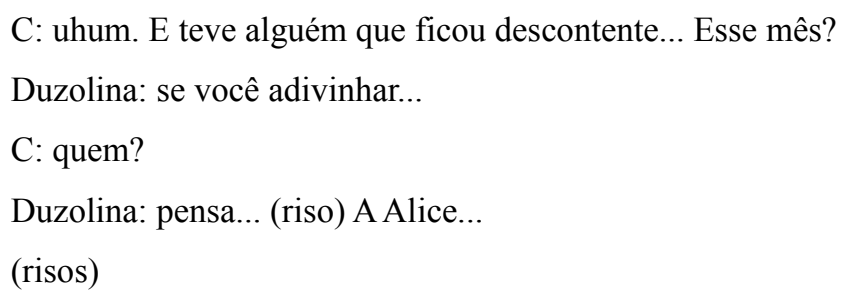
ela fala que é um Bin Laden, que é um terrorismo, que não sei o que... Tá... Então, se posiciona... (...)

(...)

Duzolina: Antes de digitar a escala, ontem mesmo, ela falou para mim, "É, você viu que eu fiquei sem final de semana?", falei “puta Ali! não vi... então vou ver a tua escala com carinho para botar um final de semana para você", aí olhei, olhei, olhei e falei "oh... tem essa possibilidade... a fulana, faz plantão aqui... essa faz noturno e não sei o que... e dá para você tirar esse final de semana, é tranquilo, é só conversar com as pessoas", “Ah não, mas daí eu vou ficar devendo muita hora" (risos) "Já estou com 14 horas devendo e vou ficar com mais não sei o que...", "Mas o que você quer? Você quer o final de semana ou você quer pagar as suas folgas? Suas horas?", "Não, não, deixa assim, deixa assim, que eu vou pagar minhas horas", "Mas meu, não estou te entendendo, então para de reclamar. Se você aceitou, se você concordou..."

(Quinto encontro)

19 Para usar a imagem cedida por Alice: “Eu estou falando que a gente é o próprio 'talibã' ... vocês não estão achando graça..." (Terceiro encontro). 
Duzolina fala em discurso direto. Nesse modo de enunciar, aquele de quem se fala fica sendo responsável pelo discurso enunciado. Ao montar a cena da enunciação, nos mostra Alice "desmascarada". Uma Alice que deveria se responsabilizar por suas escolhas e também por sua fala, mas que resiste em fazê-lo. Quem a responsabiliza, em ato e em conteúdo, é Duzolina.

É como se o descontentamento de Alice já fosse esperado. Seu modo de agir, ou reagir, sua ironia, a tentativa de resistir, é tomada como falta de posicionamento. A resistência, o terrorismo, aparece como falta: de posicionamento; no grupo. A falta é preenchida com a presença da chefia, seu posicionamento, seu discurso, sua ordem.

De terrorista a 'café-com-leite', o sucesso da mediação.

Diante do fim do incêndio, ou passado o terror, vejamos como se comportam as demais participantes:

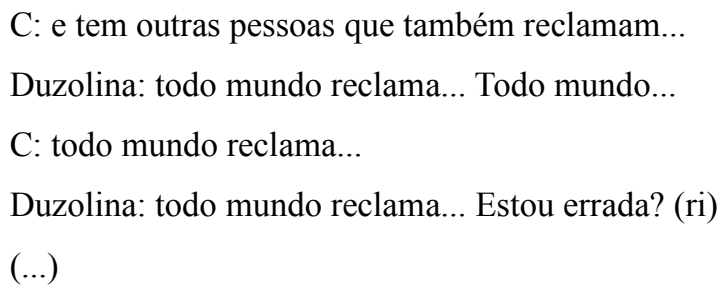

Maria: Tem gente que fala assim "esse ano não folguei no feriado nem uma vez", mas esse ano também não pediu o feriado nem uma vez...

Duzolina: Exatamente isso!

(Quinto encontro)

A reclamação, o que seria o contraponto, é tomada como algo fugaz, disperso e improcedente.

O grupo parece se movimentar no sentido de inflamar-se com uma faísca lançada e, na sequência, abrandar o entusiasmo e retomar a "consciência". As profissionais pareciam apoiar as críticas e reivindicações de Alice, que eram mais calorosas quando Duzolina não se 
encontrava (segundo e quarto encontros). No quinto encontro, quando Alice não está, falam das reclamações como se as tolerassem. As reclamações sobre a escala não desestabilizam o funcionamento institucional. Tal qual ondas de calor, elas vêm e vão... Tal qual bombas ou panelas de pressão, as pessoas podem vir a explodir, mas as bases da instituição hospitalar não se abalam.

A fala de Laura parece conter uma denúncia, um reconhecimento que surge em meio a um questionamento. Seria um hábito reclamar da escala? Estaria ele tão arraigado que faria parte do funcionamento institucional? Um hábito que não leva a nada e que aparece quando não há "assunto"? Um corte neste ponto poderia fazer pensar ${ }^{20}$. Mas o corte não se sucedeu à denúncia.

\section{O coordenador deslegitimado...}

Desde a formação do grupo o coordenador apresentava especial interesse que participasse a chefe ou a subchefe da enfermaria, buscando a melhor forma de garantir a presença de uma delas. No final do terceiro encontro ele cobra, de maneira indireta, a participação de Duzolina. Esta, por sua vez, lembra sua advertência anterior à montagem do grupo:

C: (...) Queria retomar que na próxima terça a gente também está aqui, meio dia, se vocês puderem chegar no horário...

Duzolina: então, na próxima terça também não venho...

C: você não vem, também?!

Duzolina: tem grupo da X...

Alice: e dependendo de quem esteja acho que talvez eu não posso vir, porque tenho que ficar na unidade... A Nicoly [outra enfermeira da pediatria] estava, né...

Duzolina: é, dá para a gente combinar para a Nicoly chegar mais cedo. Mas não dá... Falei que ia ser difícil para mim...

C: tá... E esse grupo da X só acontece...

Duzolina: uma vez por mês.

20 Por exemplo: Falta mesmo assunto a ser conversado, discutido e refletido por aquele grupo naquele contexto? Ou ainda, sobre o que não há o que se dizer? Se não há mesmo nada a ser dito, então porque é justamente o assunto da escala que surge? Este tempo não poderia ser aproveitado de outra maneira? Ou há neste "assunto" algo cuja importância se desconhece? 
C: ok...

Duzolina: segunda terça-feira. Como a segunda terça-feira foi feriado, eles jogaram não nessa, para a outra.

C: tá...

Duzolina: entendeu?

C: bom, vou pedir para chegar no horário... (...)

(Terceiro encontro)

O coordenador se mostra contrariado. A imprevista falta de Duzolina o surpreende e ele solicita explicações. E justamente nesse quarto encontro a falta de Duzolina mostra a importância de seu lugar para o coordenador:

C: (...) Uma coisa que é interessante pontuar, que eu acho que pode ajudar vocês também a pensar... É aquilo que a Duzolina falou (...)

C: (...) E no terceiro [encontro] a gente começou falando disso porque a Duzolina não tinha vindo, né. E... e foi curioso porque, ela não está aqui hoje, né, mas até ela podia... Também participar dessa parte, foi curioso, porque tudo que a gente ia colocando como dificuldade a Duzolina colocava como que para ela era fácil de fazer. (...)

(Quarto encontro)

É como se o coordenador buscasse preencher esse espaço vago, o que lhe parece importante. Ele evoca a figura de Duzolina, seu discurso, sua função.

C: (...) vocês falam que Natal e Ano Novo não tem problema...

Alice: não.

$\mathrm{C}$ : porque...

Laura: porque é uma regra de-fi-ni-da.

Camila: tem... Porque quem folgou o Natal no ano passado, então olha a escala do ano passado, então já resolve tudo.

C: isso...

Alice: se você não quiser você troca com alguém que queira trocar, entendeu?

C: aham... Então parece que tem alguns problemas aí que é tipo de priorizar essas regras, têlas claras... (...) acho que pode ajudar muito. De vocês terem a relação de quem folgou, de quem não folgou. Acho que fica mais...

Camila: não adianta.

C: não adianta? 
Camila: "eu vou pedir! Se eu ganhar..."

(Quarto encontro)

O coordenador tenta identificar o "problema" e isolá-lo. Nesse movimento, a palavra "ajudar" marca a posição de alguém que apresenta soluções. Ao se "posicionar" (em referência à critica de Duzolina à Alice, p. 57-58) assume o lugar vago deixado por Duzolina, o lugar de quem organiza, orienta, ordena, resolve, apazigua.

No mesmo trecho, ainda, podemos verificar como as profissionais passam a se relacionar com o coordenador a partir dessa posição assumida. Elas facultam a ele o papel de liderança e voltam a permanecer no lugar de queixa e de informante dos obstáculos que impedem as ideias de serem executadas. Vejamos outro momento:

C: ah... E porque também se vocês decidem juntos, quais vão ser os critérios, por exemplo... Se faz uma reunião para decidir os critérios... "os critérios são esses, a organização vai ser essa..." vocês podem reivindicar juntos, para que eles sejam cumpridos. Ou não?

Camila: você tem que falar com a chefe... (ri)

(Quarto encontro)

O quarto encontro é marcado pelo grande empenho do coordenador em fazer com que o grupo de profissionais reflita acerca de sua prática e promova estratégias para lidar com as dificuldades e impasses que as incomodam, principalmente em relação à montagem da escala mensal de trabalho. Nesse movimento do coordenador, contudo, está embutido o pressuposto de que, para chegar a isso, elas devem se organizar e tomar decisões, tomar as rédeas do funcionamento institucional. Ele se propõe a "ajudá-las" a "resolver" o problema. Camila, com uma frase, resiste tanto a colocar o grupo no comando das decisões quanto ao próprio lugar de comando assumido pelo coordenador. A hierarquia é evocada como algo a ser respeitado. A liderança possível, nesse caso, só pode advir da nomeação da chefia.

De analista a bombeiro o coordenador-mediador é desautorizado.

Com a presença de Duzolina no ultimo encontro, o grupo mostra outro movimento. Todas as alternativas propostas pelo coordenador passam a ser apresentadas como se fossem as melhores soluções, e isso não apenas para ela, mas também para as demais participantes. Ela traça um planejamento e esboça a implementação das medidas. As outras profissionais 
apostam que ocorrerá mudanças importantes com a execução das ideias que na semana anterior pareciam não servirem para nada.

Duzolina: mas é muito melhor quando a gente faz. E eu acho que assim, se começar a dar muita... briga também na parte de técnica, tem que fazer esse levantamento...

Laura: mas fez...

Maria: fez, Carla fez...

Laura: como esse agora calhou de ter muito feriado, (...) a Carla levantou, desde janeiro, quem que folgou feriado (...)

Maria: é...

Duzolina: quantos feriados... é, mas tem que fazer isso! Porque com esse quadro...

Laura: porque às vezes parece que é uma situação mas quando vai ver na real não é assim.

Duzolina: e aí com esse quadro, eu acho que tem que fazer. Se fez dos auxiliares eu acho que legal... Porque na hora de fazer até... Não ficar retendo o quadro, né?, Porque deve estar com ela, porque não tá, eu não vi isso daí...

Laura: até teve uma pessoa que a Carla viu, que esse ano não folgou um feriado... (...)

(...)

Duzolina: (...) Mas então, eu não sabia! Então é legal fazer isso e deixar lá exposto... Né? Até na pasta de escala.

Maria: a Alessandra não folgou nenhum feriado, e acho que é uma das que deu mais plantões, assim... (risos) e aí a Carla falou "você não quer folgar esse?", e ela "não, eu não quero" (risos)... Aí ela falou "mas você tem certeza?", "não, não quero".

Duzolina: então, mas é legal assim, para todo mundo ver...

Laura: mas a prioridade dela é outra... Por exemplo, às vezes ela precisa folgar uma semana inteira porque... Os negócios da escolinha da filha dela... Então ela pega as folgas todas que ela tem... E joga naquela semana...

Maria: é que nem ela falou "eu não quero porque todas as minhas folgas já estão comprometidas, então não quero folgar no feriado, entendeu?", então vai de cada pessoa. Que nem, tem pessoas que querem folgar o feriado e tem outras que não querem folgar o feriado...

Duzolina: mas aí é legal, eu acho que é legal ter esse quadro, e ter lá exposto... Não guardar com uma pessoa só... Que nem o quadro das enfermeiras, está guardado no bolso da Sabrina e da Joana... Não está com a Anely nem comigo.

Laura: tem que deixar na pasta de escalas...

Varias: deixa lá...

Duzolina: digita, faz cópia. Uma você guarda no bolso e a outra põe na escala. Eu falei "vamos guardar, porque o papel some, né?" Então falei "deixa uma no e-mail e a outra põe na pasta da escala..." porque quando você vai fazer você fala "Oh, a Duzolina folgou dois finais de semana aqui, no outro ela tem que ficar bem quietinha... tem que pegar o feriado", e eu 
vou concordar, porque está ali... Não tem o que esconder.

C: uhum...

Duzolina: Né... Eu acho que é a melhor saída mesmo...

O longo trecho mostra como Duzolina "bate na tecla" do que tem que ser feito. Além disso, ela também avalia as atitudes, as iniciativas. Fala como líder que é. Nesse modo de organização a introdução de mudanças segue o caminho de fazer saber a chefia, esta estar de acordo, aprovar e acreditar na eficácia do plano, para aí mobilizar recursos e esforços para que a implementação seja efetiva. A melhor solução é a que cala reclamações, que extingue incêndios e desarma bombas.

Assim posto, Duzolina mostra-se eficiente naquilo que lhe cabe.

Por sua vez, o coordenador aparece do lado de quem colabora para a manutenção do funcionamento institucional. Um bom auxiliar da chefia...

\section{A construção de um lugar de legitimidade para o coordenador}

No último encontro o coordenador solicita às participantes que realizem uma avaliação de como foi para elas aquela experiência. No conteúdo do discurso de Maria e de Laura ambas referem ter sido um espaço para se falar e pensar sobre coisas que mudam a visão. As expectativas apresentadas no primeiro encontro foram alcançadas. Verificamos linearidade em relação ao conteúdo e à forma discursiva. Não há surpresas nem desvio de rota. Ambas parecem sair tal qual chegaram, como quem vai à padaria comprar pão para o café da manhã e volta com o pão:

Maria: Eu começo. Eh, para mim foi uma oportunidade boa, que você estar aqui, né, entre colegas, expondo as situações, de tudo que aconteceu. E é bom você ouvindo as opiniões de outras pessoas, você pode enxergar de outra forma, né... Eu acho que é... Um aprendizado para mim, assim, foi, de estar crescendo, de estar enxergando as coisas de maneira diferente... Acho que para mim foi isso...

C: o que você acha que conseguiu enxergar de outra forma... O que você acha que mudou...

Maria: não... É que você vai tendo a visão de outras, das outras pessoas, né. E com a visão de outras pessoas você começa a pensar, às vezes, que o que você pensa não é tão certo assim. 
Então, acho que foi isso.

(Quinto encontro)

Maria: [...] O que estou esperando do grupo é... Acho que melhorar, né, o nosso trabalho. A gente ter informações dos outros profissionais, saber o que cada um passa, como que lida com as situações, e tá... Uma forma de melhorar.

(Segundo encontro)

Laura: eu achei bacana assim ter um espaço para você falar sobre coisas que você precisa falar, né, e às vezes não tem oportunidade... Eu acho bacana esse negócio de ficar entrosando os plantões e ficar falando sobre esses assuntos, que eu acho que melhora o relacionamento entre os plantões. $E$ isso também, muda um pouco a sua visão, assim, às vezes você pensa que o problema é só com você, mas aí você vê que os outros estão compartilhando as mesmas queixas que você, e aí você vê isso de uma outra maneira também. Eu acho que poderia ser um grupo maior, seria mais interessante, né... se tivesse mais pessoas participando.

(Quinto encontro)

Laura: então... eu sempre gosto de participar desses grupos assim, acho que te ajuda a ver as coisas de uma outra maneira, (...) que você fica com foco muito centrada em uma coisa e vai acarretando uma série de stress, né, você fica insatisfeito com muita coisa. Eu acho que essa é uma oportunidade de você ampliar a sua visão das coisas, e ver que esses pequenos detalhes do dia a dia fazem parte da rotina e... Você vai ter que superar. Acho que o grupo vai ajudar um pouco nisso.

(Primeiro encontro)

No discurso de Duzolina nota-se mudança em relação às expectativas iniciais, tanto em relação ao conteúdo quanto à forma discursiva:

Duzolina: É... Eu acho que é uma pena o pessoal... Os técnicos da manhã não estarem participando. (...) Uma pena. Porque... E de enfermeira também, seria muito bom se tivesse pelo menos uma enfermeira da tarde, (...) Vocês estão entendendo o nosso lado, o das enfermeiras, mas, assim, seria legal ter outros, né... Do outro plantão, para entender também o que a enfermeira da tarde pensa. Né? O que nós estamos planejando, acho que foi muito bom ter vindo à tona esse assunto, que a gente, as enfermeiras da manhã, está começando a 
conversar com as enfermeiras da tarde... (...) para acertar os ponteiros, para não ficar... Porque a rixa mais é da manhã e da tarde. A noite é mais independente... Para a gente acertar, (...) o acordo como vai fazer e tal. (...) Então, isso seria muito bom. Se todo mundo... Se continuassem essas reuniões, se pudesse implantar isso daí em um horário... Até, até duas reuniões...

(...)

C: ah, tá... Com a gente, psicólogos? Ou só entre as enfermeiras?

Duzolina: não, com os psicólogos, porque (...) vocês acabam levantando, direcionando, ouvindo, sei lá... E fazer, assim, pelo menos uma vez por semana... (...) que achei essa experiência muito boa. De fazer... É... Um grupo mais mix, assim, dando até oportunidade pro pessoal da noite participar, manhã e tarde. Para misturar enfermeiro técnico... Fazer tudo junto. Para estar abordando não só problema de escala, que isso é uma vez por mês que é falado, mas problemas... Tem picuinhas que são passadas entre plantões que... Que se a gente conseguisse ouvir... Ia ser bom também...

(Quinto encontro)

Duzolina: ah, eu aceitei para colaborar com você (ri), na sua tese, e eu acho que é uma oportunidade da gente estar falando e espero que a gente tenha alguma... Um crescimento, que saia alguma coisa produtiva, né? Que a gente, que você possa... Não sei se vai sair só da gente ou se você vai trazer alguma coisa para a gente, para a gente melhorar, alguma coisa assim... Né? Como profissional, no atendimento, não sei...

(Primeiro encontro)

Duzolina começa apontando que para ela há a certeza de que o grupo irá ajudar o coordenador-pesquisador, já quanto à ajuda que este pode dar ao trabalho e às profissionais parece ter dúvidas. Ao final, Duzolina refere ter sido ajudada, e mostra alguns dos pontos. Fala por meio de meta-discursos e reticências. Parece estar construindo seu pensamento e argumento no momento mesmo em que fala. Não se sabe bem o que o coordenador-psicólogo faz, se ele acaba "levantando", “direcionando", “ouvindo", sabe-se lá... Mas sua presença parece ser importante.

$\mathrm{Na}$ fala da enfermeira podemos perceber como as profissionais se organizam em grupos que se tornam sujeitos das ações: o plantão da tarde, o plantão da manhã, enfermeiro, técnico. São os plantões, sujeito da ação, que passam a "picuinha". Como se um plantão se relacionasse com o outro e não as profissionais entre si. Também nesse momento a relação se 
dá em meio a procedimentos" 21: “ah, esqueceu a comadre lá... mas por que esqueceu a comadre?"(Trecho abaixo).

O problema da escala foi o mais abordado no que diz respeito à relação entre as profissionais. Duzolina aponta para outros que seriam importantes de serem tratados por "esse" grupo. Picuinhas a serem resolvidas, "chamas" a serem apagadas, arestas a serem aparadas. Este grupo é visto pela chefe como meio de resolução de conflitos. Surge então a proposta de este grupo fazer parte do funcionamento institucional:

Duzolina: não, mas assim, eu gostaria de ter, né... Um psicólogo, e misturar os plantões. Tanto de enfermeiro e técnico, como manhã e tarde.

Rosa: três de cada plantão?

Duzolina: Quem quiser. Manhã, tarde, enfermeiro e técnico. Misturar... E noite. E aí a gente falar sobre a dinâmica do trabalho... "ah, esqueceu a comadre lá...”, "mas por que esqueceu a comadre?".

(gargalhadas)

Duzolina: "mas aí eu vou ter que lavar a comadre do plantão do outro" fica três dias sem lavar a comadre

Laura: é problema bobo, mesquinho (Risos)

Duzolina: é idiota! (risos) (...)

(Quinto encontro)

O lugar que Duzolina vai desenhando para o psicólogo cabe dentro do organograma do hospital. Ele passaria a ser um membro da equipe, alguém especializado em resolver conflitos, problemas "idiotas" que atrapalham a dinâmica do trabalho.

Novamente aqui vemos surgir, nas palavras de Laura, a possibilidade de um corte. Se "é problema bobo, mesquinho" porque então a necessidade de psicólogo? O discurso de Laura, no modo e no contexto em que se coloca, em lugar de se constituir em um corte que faz pensar e mudar a maneira de funcionar acaba sendo apenas mais um momento em que se repete o jogo de reconhecimento/ desconhecimento.

De modo geral, as profissionais consideram que o grupo foi um espaço de ativação da escuta, da fala e do respeito entre as profissionais:

Rosa: porque você dá uma visão, os seus assuntos assim a gente acaba vendo...

21 A análise das relações por meio de procedimentos se dará mais adiante. 
Duzolina: eu acho que não é nem ele que dá uma visão. É que a gente escuta o outro falar. Várias: aham.

Rosa: aí você vai ligando né?

Duzolina: o negócio da... Que vocês falaram assim, do final de semana, do feriado... Sempre a mesma pessoa. Eu não tinha me atentado para isso. Eu vou favorecer quem colocou folga lá. Então, agora estou enxergando isso, entendeu? E aí você... Então você acaba enxergando outras coisas que você não se atentava... Você saber ouvir o outro lado, e você acaba respeitando mais o outro lado.

Maria: você percebe coisas que você não percebia...

Duzolina: é.

Rosa: tipo que vocês tinham bastante conflito na escala, eu já não sabia, eu nunca tinha percebido...

Duzolina: então... Mas tem! Os enfermeiros quase se matam... Porque que a Alice vem verbalizando...

Maria: eu achava que era mais fácil a escala entre vocês...

Duzolina: não.. É muito mais difícil fazer a nossa escala... (...)

(Quinto encontro)

Ao final, todas queriam que de algum modo aquele "espaço" se mantivesse. Apontam para a falta, algo que antes não tinha e o grupo com um psicólogo viria suprir:

Duzolina: é... Porque não adianta, se a gente se reunir... Só nós... Plantão manhã e tarde, não vai sair nada...

Laura: vai ter as duplinhas conversando... Vai formar panelinha...

Duzolina: é... Teria que ser uma coisa assim, uma coisa mais direcionada, mais séria ... (...) que nem você fez aqui, “o que vocês querem falar hoje?”, solta um assunto, discute até esgotar... Aí muda. Nem que se fosse, sei lá, uma vez por mês... Se acontecesse isso, uma proposta... Reunião uma vez por mês..

(...)

Duzolina: (...) Eu acho que seria bem mais produtivo, você entenderia o outro lado da pessoa...

Eh... Acho que a gente ficaria mais próximo um do outro...

C: uhum...

Duzolina: e até um... Né? Se, de repente, não só...

Laura: o clima melhora...

Duzolina: o clima melhora... A motivação melhora, tudo melhora, né.

(Quinto encontro) 
Para Duzolina este foi um grupo milagroso... No qual tudo melhora. O grupo, com um psicólogo, seria fundamental para a manutenção da harmonia da equipe. A seriedade e o direcionamento são apontados como marca para atingir os referidos resultados.

$\mathrm{Na}$ avaliação final, a construção de um lugar de legitimidade para o coordenador como figura diferencial no processo.

$\mathrm{Na}$ fala de Rosa surge a comparação com o grupo realizado por Clarice, como vimos, a outra psicóloga que também trabalhava na pediatria na época:

Rosa: Pra mim foi bom, é, foi diferente do que eu tive com a Clarice. Até tinha as meninas que queriam participar, mas achou que era igual, aí falou "vou dar a vez para outra pessoa" escreveram lá na, na folha... Eu falei “vou ver se é igual, né?” (ri). No fim é diferente. Porque a dela tinha dinâmica, assim, e com você não teve. Mais conversação, né. E... Mas eu gostei. Tudo já foi falado aqui, assim... Essa visão de poder estar olhando a ideia do outro e completar a da gente, modificar a sua própria, né, que às vezes a gente pensa uma coisa e não tá muito... E não tá muito correto, aí você acaba vendo novas ideias e acaba modificando... Pra melhor...

C: que tipo de, de dinâmica que a Clarice fazia com vocês?

Rosa: ah, ela fazia várias, quase todas as aulinhas dela. (riso)

C: é?

Rosa: é... Deixa ver se eu lembro...

Laura: eram mais dinâmicas voltadas assim para seu autoconhecimento...

C: tá...

Laura: para você poder se ver no meio do grupo. Não só do seu grupo de trabalho, mas... Em casa também...

C: uhum...

Laura: pra você se conhecer mais e se posicionar em relação às coisas. Tipo "não está satisfeita", mas às vezes nem você mesma sabe o que está te causando essa insatisfação, então ela buscava fazer você enxergar você, como você é, como você poderia ser...

(Quinto encontro)

Rosa: eu participei da Clarice, o último...

(...)

Rosa: foi muito bom.

(...)

Rosa: É, deixa a mente mais ampla... Não fica em um foco só, como ela disse... Dá para abrir a 
Para Rosa este grupo é marcado pela "conversação", marca que o diferencia do outro, no qual faziam "dinâmica". A primeira se liga à interação e a segunda à introspecção. O não saber referente às expectativas iniciais sobre como seria o grupo toma um contorno de experiência satisfatória para as participantes. Contudo, o resultado final parece ser bastante próximo em ambos. Salvo o "outro" não se limitar apenas às questões do trabalho. Por mais que este seja um grupo diferente, ele atende, também, às mesmas expectativas geradas pelo "outro".

\subsection{A relação com a clientela}

No primeiro e segundo encontros o tema central discutido foi a clientela e a maneira de se relacionar com ela.

A clientela de um hospital é o paciente e, no caso da pediatria, seu acompanhante também. Esta, contudo, é a postura adotada por nós de partida e sustentada por nossas análises. Há quem considere que o acompanhante não seja parte da clientela da pediatria. Nossa posição deriva de como compreendemos a clientela, a saber, para quem a instituição se faz, a quem dirige seus serviços. Desse modo, por ser considerada peça fundamental para cuidar do paciente a partir das orientações fornecidas pela equipe de saúde, podemos considerar que há uma prática cujo alvo é o acompanhante. Nesse sentido, o acompanhante está em posição hibrida, pois recebe o serviço para ser capaz de ajudar a cuidar do paciente.

Por esse motivo, este tópico sobre a clientela será dividido em duas partes. Uma para falar da relação com a criança e outra destinada apenas à relação com os acompanhantes.

A primeira vez que a clientela surge no discurso das profissionais é na apresentação que Martha faz de si, e o paciente aparece na comparação com a clínica de adultos, a Clínica Médica:

Martha: (...) Trabalhei 3 anos na UTI em Osasco, no Hospital C.... Aí depois eu vim para cá, para a clínica médica... Onde foi meu trauma... E vou fazer 11 anos que estou na pediatria. 
C: clínica médica foi um trauma?

Martha: nossa! (risos)

C: por que?

Martha: porque... Não sei, de repente foi por eu sair de um lugar onde só nasce criança e aqui na clínica médica o perfil é bem diferente, né... Bem diferente... Aí eu ia... Tanto que se eu não conseguisse uma transferência, assim, eu teria pedido a conta... Porque eu não teria ficado lá. Eu não... Assim... Eu não me dou bem em clínica de adulto.

C: uhum...

Martha: então...

$\mathrm{C}$ : por causa de... Falecimentos?

Martha: também.

C: é?

Martha: patologia muito grave, com adulto é tudo mais difícil... Não, não tenho esse perfil... Para adulto não...

(Primeiro encontro)

O perfil é ora usado para falar da clientela, ora para falar do profissional de saúde. O perfil do profissional de saúde se delineia na relação com a clientela. Há quem tenha perfil para trabalhar com adulto e quem tenha para trabalhar com criança. Na Pediatria, em oposição à Clínica Médica, é onde o profissional se sente melhor trabalhando, e tudo se torna mais fácil...

O mesmo pode ser notado no discurso de Maria:

Maria: (...) sempre quis trabalhar com criança e a pediatria para mim acho que é o lugar ideal. Adoro pediatria.

C: tá. Ah... Por que especificamente?

Maria: ah, porque eu gosto de criança. Gosto de lidar com criança. Eu acho que eu tenho um... Um... Acho que é... Eu me sinto mais fácil lidando com criança. Gosto muito de trabalhar com criança.

(Segundo encontro)

A relação com a pediatria e sua clientela implica a relação consigo própria. É quando a profissional "se sente mais fácil".

Todas as outras profissionais também sempre trabalharam na área materno-infantil. Quando perguntadas se gostariam de trabalhar em outro setor, em todas aquelas apontadas como possibilidade havia uma clientela materno-infantil. Rosa diz, ainda, da vontade de 
trabalhar no Centro Cirúrgico por admirar o trabalho dos grandes cirurgiões.

Duzolina é a única que se coloca de modo diferente. Apesar de sempre ter trabalhado na Pediatria, ela refere gostar de paciente cirúrgico e trabalhar com feridas. Contudo, fora chamada para trabalhar na UTI Adulto do mesmo hospital e rejeitou a proposta: "não, agora eu não quero mais. Agora já me apaixonei, (risos) já domino a clínica, vou mudar para que né?"

As profissionais da pediatria gostam de trabalhar com sua clientela.

\section{A criança}

Começaremos, então, pelas crianças.

$\mathrm{Na}$ pediatria a criança é a principal figura que aparece no discurso das profissionais quando se trata do paciente, mas também existe o bebê e o adolescente. Os recém-nascidos não se encontram na Enfermaria da Pediatria, mas sim no berçário e UTI neonatal. A configuração desses pacientes da pediatria começa a ficar mais intrigante quando eles passam a ter um perfil distinto dos pacientes da UTI Pediátrica. E, justamente na diferenciação com a UTI Pediátrica, as profissionais começam a caracterizar essa criança.

Duzolina: E eu acho que o legal da pediatria é que... Você vê também, a criança afunda muito rápido, né, e acaba indo para a UTI e às vezes até a óbito. Mas, também, ela melhora muito rápido. Então, assim, a recompensa para a gente que trabalha lá, que você, a criança chega ruim, você dá os cuidados e você, daqui a pouco você vê ela jogando bola, te atropelando pelo corredor, correndo...

Alice: te dando injeção de água...

Duzolina: Então, isso é muito gratificante. Isso que eu acho que faz a diferença das outras clínicas. Porque você trabalha sempre com alegria... na clínica. Tem os momentinhos, né, que são bem raros, que a criança afunda... vai para a UTI... Sei lá, acontece coisa pior. Mas geralmente é sempre para bom, né. A criança chega ruim, você cuida e ela fica melhor. (...) Não é uma clínica pesada... É mais tranquila.. Tem mais vida...

Laura: que nem na pediatria se a criança piorar muito ela desce para a UTI. Mas se ela está na UTI, ela pode piorar piorar e não sai pra lugar nenhum...

Duzolina: mas se ela sair de lá vai para o céu, né? (riso)

Laura: ou céu, ou ela melhora e volta para a pediatria... A UTI é difícil por isso, não tem para onde... Mandar para... 
Duzolina: é... Salvo os casos que é "se parar parou", que vai morrer ali, na enfermaria, com a gente... Então, tem esse... Esse corte, né? Ficou ruim, desce para a UTI, o pessoal se vira. Volta para nós quando está melhor. Então a gente pega sempre mais a parte alegre da criança.

Rosa: às vezes sobe, depois desce de novo, depois sobe... (risos)

Duzolina: mas você só vê a parte... Melhor... Da criança.

(Primeiro encontro)

A criança aparece como quem chega ruim e sai bem após ter recebido os cuidados necessários por parte da equipe de saúde. A criança aparece como objeto-alvo da ação da equipe. Tal ação, transforma uma criança doente em uma criança saudável, que brinca.

Trabalhar com esse tipo de paciente é recompensador. A velocidade dessa melhora parece ser fator importante, assim também o número de vezes em que essa recompensa ocorre, na diferenciação da pediatria com outras clínicas. A criança que piora, que "afunda", deixa de ser paciente da pediatria e voltará a sê-lo quando estiver melhor. É raro, portanto, ocorrer morte na pediatria.

Na oposição com a UTI o paciente da pediatria tem mais vida, mostra a sua parte melhor...

Alice: eu entrei na UTI e depois fui para a pediatria também. UTI pediátrica.

C: e porque você pediu...

Alice: porque eu pedi.

C: tá... E você prefere estar trabalhando na pediatria...

Alice: muito...

(...)

Alice: (...) Era uma coisa meio... Massacrante. (...) Mas assim não por questão de ser criança grave ou... Não. Mas eu queria ter criança correndo, criança brincando... E lá não tinha. Era tudo... Né... Quietinho, caladinho... Você só via as pessoas sofrendo ali embaixo, mãe sofrendo. Não vê, agora que lá embaixo a mãe interage com a criança, interage com a equipe, antes não tinha isso. E lá em cima a gente tem tudo isso: a mãe xinga, briga, chora, bate... Faz o diabo, mas está lá, né... Tendo uma resposta. Você não fica, que nem, porque lá embaixo antigamente parecia que você estava dentro de um aquário, né, eram uns negócios de vidro assim e você ficava dentro e tinha 3 horários de visita, então as pessoas vinham, ficavam um pouquinho e ficavam no vidro... Então eu me sentia no próprio aquário. Porque você era observado o tempo inteiro. Não por ser observado, mas você vê que a pessoa queria estar ali dentro com o filho deles, era um pedaço deles e não podia. 
C: uhum... E era isso que incomodava...

Alice: Muito. Muito. Incomoda muito...

(Primeiro encontro)

A UTI é apresentada como negativo da Pediatria - é onde "não tem", em especial em termos de contato. O sofrimento se liga a "quietinho", "caladinho", a "não ter resposta". A oposição, o contato, se liga a correr, brincar, brigar, chorar, bater, fazer o diabo, estar ali. A criança saudável é a que faz contato. Os filhos são, para Alice, um pedaço dos pais. Na UTI a assepsia chega ao ponto de privar o contato com um pedaço de si. Quem aparece na posição de ser observado o tempo inteiro e de estar privado de contato não é o paciente, mas o profissional. Neste lugar Alice sente... O incômodo.

A maneira de se referir a seus sentimentos utiliza uma caracterização que poderia se destinar ao paciente. Acontece o mesmo no discurso de Martha:

Martha: (...) então, ficar naquela auto-dependência, sozinha com oito... Oito pacientes, assim... É traumático para qualquer pessoa... Então, eu, depois disso... Eu fiquei 2 dias lá, sozinha, aí eu falei “não, realmente não vai dar”, eu estava na dúvida. Ai eu resolvi, (...), que não ia ficar lá de jeito nenhum.

(...)

Martha: é que auto-dependência, auto-dependência é assim: não caminha para lugar nenhum, né... É só isso.

Laura: é, não evolui! Vai piorando...

(Primeiro encontro)

Caminhar e evoluir são termos que aparecem aproximados para falar do paciente que melhora, do paciente com o qual essas profissionais gostam de trabalhar. O paciente que melhora é o paciente que circula.

Ficar na alta-dependência, ou auto-dependência ${ }^{22}$, sem caminhar para lugar nenhum, tal qual o paciente que lá está, é insuportável para o profissional. A saída é sair. Não ficar... É fazer o que o paciente não pode fazer.

No discurso de Laura, percebemos um colorido que parece ir além. Nota-se certa

22 Há um setor na Clínica Médica deste Hospital denominada Alta-dependência, onde estão internados pacientes que apresentam uma dependência elevada dos profissionais até mesmo para suas necessidades mais fundamentais, tal como comer, ir ao banheiro, tomar banho, se virar na cama, etc. Oito pacientes é a lotação máxima desse setor. Contudo, na gravação fica demasiado difícil dizer com certeza se a profissional diz altadependência ou auto-dependência. Pelo contexto, contudo, nos parece que qualquer uma das duas palavras cabe bem. 
mistura entre profissional e paciente:

C: que é parecido, na Clínica Obstétrica... É... Com o Centro Obstétrico é parecido...

Laura: é parecido. É... Só que no CO [Centro Obstétrico] é mais interessante, né. Que lá a gente vai lá para nascer bebês, né? Não é que nem na, no centro cirúrgico que tem muitas amputações, né, retirada de órgãos. Corre-se um, o risco de vida é muito maior. O risco de morte.

C: Uhum...

Laura: é bem maior... Eu tenho uma certa dificuldade em lidar com essa parte também, de trabalhar naquele limite lá de vida e morte...

(Primeiro encontro)

Uma frase de Duzolina também chama a atenção nesse sentido: "Assim, raramente eu me apaixono por alguma criança. Gosto de todos, gosto de ficar no colo...".

Tanto no discurso de Laura quanto no de Duzolina o sujeito se faz indeterminado, conferindo ambiguidade à frase. Quem nasce no Centro Obstétrico? Quem corre o risco de morte? Quem fica no colo?

A relação com a clientela apresenta uma marca de indiferenciação.

Com Rosa, essa mistura não ocorre. Nitidamente a profissional se coloca no lugar do paciente:

Rosa: eu tenho uma história assim que, esses últimos tempos, que eu fiquei bastante comovida com o que aconteceu, assim, com o Caio. (...), não sei se foi uma, uma vacina que ele tomou, que deu uma inflamação toda nele... Que assim, eu cuidei dele, eu fui levar ele em encaminhamento, fazer um exame no ambulatório, na cadeira de rodas, ele estava cheio de bolhas, pelo corpo inteirinho. Aí a gente passava, assim, o vento do corredor... Ele, assim... Ele tremia, tremia... Fui fazer uma avaliação, aí eu falei "meu Deus, parece que estou sentindo essas... esse vento, essas bolhas que ele tem" assim no exame. Até cheguei e falei para Jaine "Jaine, acho que eu, a gente fez errado em descer essa criança, acho que eles teriam que ter subido" porque o que ele passou foi muito traumático para ele, né. E essa criança há dias estava no isolamento. (...). Aí essa criança foi piorando na UTI, e eu ficava sempre perguntando para as meninas, pela internação... Porque a gente sente! É uma coisa assim que você carrega. Minha sogra estava na minha casa, cheguei, comecei a contar para ela... É uma coisa assim, falei “nossa! tá tão terrível de se ver, é uma coisa assim, né?” E eu sempre procurava saber... Eu sei que essa criança ficou mais de mês, fez várias cirurgias, depois no final ficou bem, assim, que eu, eu não acreditava no que eu via... Eu achava que ia, quando 
desceu, ia ter óbito. Porque estava todo inchado... Cheio de bolhas... O piupiu dele não tinha como mexer de tanto... É... Por tudo, é terrível!

(Primeiro encontro)

Os sentimentos e as sensações parecem migrar de um para o outro na relação que Rosa estabelece com a criança. Rosa veste a pele do paciente... Sente o vento... As bolhas... Ao mesmo tempo, o trauma e a terribilidade, experiências que assim foram vividas por Rosa, são alocadas no paciente. O procedimento "levar ele em encaminhamento" determina toda a relação que se desenvolve. A criança aparece como quem sofre a e na ação da profissional. A situação envolve a técnica de enfermagem de tal forma que transborda os muros do hospital. É com a sogra que Rosa encontra a possibilidade de dividir... O terrível da situação. Perguntar aos outros profissionais pela condição do paciente se torna necessário quando se vive a expectativa de melhora, o receio do óbito, a torcida e a dor do paciente.

O paciente é alguém que pode mobilizar muitos sentimentos. Eis um episódio que Laura nos conta emocionada:

Laura: (...) um dia que eu desci para a UTI para cobrir a UTI, acompanhei uma criança, a criança piorou, piorou, piorou... Mas eu fiquei com ela lá, só 6 horas! Foi o suficiente para me apegar à criança. Era até uma adolescente. Aí ela foi piorando e à tarde ela veio a dar óbito. Em todo o procedimento ela falava "Laura, segura a minha mão", ela já tinha uns 13 para 14 anos de idade. Isso quando ela já estava na UTI, naqueles procedimentos de entubar e tudo, e ela chamava "Laura..." e ninguém sabia quem era, porque eu não era da unidade... Aí no outro dia encontrei a menina da UTI no elevador, ela falou "sabe aquela menina que você ficou ontem?” eu falei “Ah, sim. Ela está bem?”, “não, ela morreu” Ahf!

(...)

Laura: nossa, fiquei muito mal. Aí eu não conseguia mais falar, sabe... (chora)... Aí, eu odeio ir pra UTI. (...) Eu fiquei com pânico de UTI... Não quero mais ir para lá! Sempre que eu estou lá eu acho que vai acontecer isso...

(Primeiro encontro)

Na cena, a relação da profissional com a paciente é entretecida pelos procedimentos. Como podemos notar, não se trata mais de uma criança, mas sim de uma adolescente.

A adolescente aparece como sujeito das ações. Ela solicita que Laura execute ações que ultrapassem os procedimentos técnicos de enfermagem. Parece solicitar amparo, proteção, acolhimento... Laura parece se deslocar, paulatinamente, do lugar de profissional para o lugar 
de mãe justamente no momento em que é solicitada a proceder para além da técnica. Seis horas pode ser tempo suficiente para se apegar e se doar com tanta intensidade a ponto de constituir forte vínculo e produzir indiferenciação em seu papel.

Com a morte da paciente a profissional se desorganiza, sofre sobremaneira, e desenvolve um "trauma" no qual a situação é invariavelmente reeditada em sua vida toda vez que precisa trabalhar nesse setor. Novamente, aqui, percebemos que a relação com o setor tem estreita ligação com sua clientela. Ir para a UTI parece ser imposição da qual não se pode escapar. Tem que ir, mesmo quando não se quer, quando se tem ódio ou mesmo pânico.

Num outro momento, Laura tenta explicar sua dificuldade em lidar com o óbito:

Laura: e essa coisa assim de lidar com óbito, com situações muito difíceis, eu acho que o problema meu é eu me colocar no lugar da mãe... Porque eu tenho filhos de várias idades, então, todas as crianças da pediatria um eu vou comparar a um filho meu... (risos)

(...)

Laura: (...) então, você sempre associa... E você se põe no lugar daquela pessoa... A mãe está lá, em um desespero, terrível... Às vezes, está na razão dela, ás vezes não está na razão dela. Mas você pensa "nossa... se fosse meu filho que estivesse naquela situação, será que eu conseguiria me controlar também? Será que eu teria forças para tomar uma decisão difícil?"

(Primeiro encontro)

Parece haver um reconhecimento da associação entre identificação com a mãe e dificuldade em lidar com o óbito. A construção do forte vínculo, contudo, é o que está fora da explicação "racional” de Laura. Esse elemento, todavia, é o que nos leva a construir a imagem de um deslocamento de lugar, e não só uma questão de empatia. Ao ocupar o lugar de mãe, os acontecimentos ganham outro sentido, os afetos, outra dimensão.

Duzolina: Mas aí eu pergunto: "E os nossos pacientes crônicos? Que não caminham para lugar nenhum?".

(...)

Laura: esse é o ponto difícil, da pediatria, de você lidar... Sempre pega. Com todo mundo (...)

Laura: (...) O que mais pegava para mim é assim, aquelas crianças abandonadas. (...) para mim é o mais difícil... E acho que como a mãe não está assumindo, aquela coisa, parece que tem gente que quer assumir no lugar da mãe, entendeu? Você começa a desviar a situação. Alice: A gente tem a maternagem muito forte! A gente acaba adotando pra gente. (...) 
Pacientes crônicos são o ponto mais difícil. Eles não circulam, não caminham, e despertam sentimentos "perigosos" nas profissionais. Estes sentimentos são aqueles que de alguma forma estão ligados à "maternagem". A identificação com esse lugar de mãe ocorre diversas vezes nas falas das participantes. Por exemplo, nesta fala de Duzolina:

Duzolina: Eu sou difícil de me apegar... a uma criança, essa coisa "ah, coitadinho, abandonado" vou lá, compro um monte de roupa e levo pra criança... Não. Eu consigo separar bem: o cuidado que eu tenho que dar, a enfermeira. Peguei minha bolsa e vou embora... para mim acabou a enfermagem. Eu passei o cartão naquela catraca eu não sou mais enfermeira. Então, eu não gosto de andar de branco na rua... justamente pra não me identificarem (risos) lógico, se acontece alguma coisa na rua é instinto você prestar assistência... Mas... Eu não tenho essa de acocar e ficar. Assim, raramente eu me apaixono por alguma criança. Gosto de todos, gosto de ficar no colo... Mas não tenho essa coisa assim de "ah, meu filho, vou cuidar, coitadinho... que não sei o que..." não. Tanto que eu tenho, assim, é engraçado, que todo mundo fala "lembra do fulano que internou aqui?, que tinha tal problema, assim, assim e assado?" "quem?". Na hora que faço a alta, que eu aperto a tecla enter pra sair o resumo de alta, eu deleto da minha cabeça.

(Primeiro encontro)

A fala se dá por meio de metadiscursos, discursos diretos, pausas e reticências, a ideia parece estar surgindo naquela hora. Neste trecho Duzolina descreve seu modo de ser enfermeira, é como ela se reconhece nesse lugar. A profissional se considera alguém capaz de separar bem, e o que fica bem separado é o cuidado da enfermeira e o cuidado da maternagem. O que a ajuda nessa separação é a catraca. Para ela, o lugar do hospital, o passar o cartão na catraca, dividem o que ela "é", com seus direitos e deveres. Podemos dizer que organizam dois modos de se constituir sujeito. Da catraca pra dentro, é automático, desapegado e compulsoriamente movido pela circulação nas relações e espaços do hospital. O instinto e os afetos ficam do lado de fora. E segundo prega Duzolina em sua fala, é assim que deve ser.

A catraca é um divisor que determina um modo de relação entre agentes institucionais de saúde e clientela. Essa relação termina quando uma das partes sai do hospital, seja o profissional ou o paciente, seja essa "saída" provisória - no caso do profissional, pois 
retornará no dia seguinte - ou "definitiva", quando os pacientes recebem alta ou morrem.

O enter do computador é o delete de sua cabeça. É como se a enfermeira fosse máquina, tal qual um computador, que após ter feito suas funções retirasse da tela e deixasse a memória livre para nova função. As relações, assim, já começam com a certeza de seu fim.

Tal qual líder que é, seu discurso toma o tom de exemplo a ser seguido. Eis a sequencia da fala:

\begin{abstract}
Martha: Já era!
Duzolina: Acabou! Não sei nome, o diagnóstico, não sei nada. A não ser aquele paciente que vai e volta, vai e volta, vai e volta, que é uma coisa crônica, daí eu guardo. "ah, fulaninho? Sei." e quanto mais paciente crônico menos eu me apego. Não quero saber! Entendeu? E adoro o que eu faço, mas eu não tenho essa coisa assim de... De vínculo e de... Me apoderar da criança, não. Eu não. Venho, trabalho, dou o meu cuidado, carinho, tudo que eu posso e...
\end{abstract} Caio fora. (riso)

(Primeiro encontro)

Catracas e teclas apresentam suas "falhas" de operação com o desgaste ocasionado pelo uso. Os pacientes que sempre retornam, que sempre passam pela catraca e que, por sua vez, sempre passam pelo "resumo de alta", parecem esgarçar a função que a catraca e as teclas operam: a primeira, de separar bem, e a segunda de apagar da memória.

Os termos guardar, se apegar, se apoderar, dar tudo o que se pode e cair fora se interligam em interessante configuração. Paciente crônico é sinal de perigo para catracas e teclas e, assim sendo, é melhor não guardar, é melhor nem querer saber, recomenda-se se apegar o mínimo possível para conseguir dar o que pode e cair fora. O distanciamento afetivo aparece como regra a ser seguida. Se apoderar seria justamente o que vai além do que se pode. O que configura um tipo de ligação que impede o profissional de cair fora.

Continuemos seguindo a conversa entre as profissionais:

Laura: é bem melhor assim, né. (riso) É mais fácil, né?

Duzolina: uma vez só. A Alice estava comigo... Que eu fiquei com uma criança pequenininha a manhã inteira. A criança mal, eu lá dando cuidado... Eu, uma residente e um interno. Colhendo exame e ficando em cima daquela criança... Eu acho que me doei tanto para aquela criança, pra ela melhorar, e aí a criança desceu mal e foi pra a UTI. Deixei a criança lá na UTI e subi. E terminou o meu plantão eu fui no banco... Com a Alice... Chegou a moça lá da UTI, a auxiliar da UTI, “ah, sabe teu filho lá, que você mandou para a gente?”, “ah, sei. E aí, ele está melhor, 
entubou?", "Morreu". Ahr! Quando ela falou "morreu”, mas eu me revoltei de um jeito. A criança tinha HIV positivo, e eles não estavam investindo muito na criança. Então, quando falou isso, mas eu fiquei tão chocada, comecei a chorar no banco e falei "aquele médico, não sei o que, não sei o que" Eu desabei falando um monte. Falei e a Alice "Calma Duzolina! Calma Duzolina! Para de chorar! Duzolina!” (risos) e me puxava para a gente sair do banco. Porque eu... Fico nervosa, eu começo a falar mais que a boca, né. Falar coisas que não devia... E aí acho que foi a única vez que eu descompensei assim bacana, né?

(Primeiro encontro)

Segundo dissemos em outro momento, o procedimento parece ser o meio pelo qual o profissional desenvolve a relação com o paciente. Os procedimentos constituem a relação que promove tantos sentimentos na enfermeira.

A fala de Laura marca abrupta mudança no discurso de Duzolina, que prossegue dizendo de uma vez que foi única. A morte aparece como avassaladora, o limite do qual não se pode escapar, que acarreta a desestruturação de si e impõe a reorganização da forma de se constituir enfermeira. Mobiliza a constituição de si e a relação que estabelece com o trabalho. Não se pode confiar tanto assim na catraca para se proteger e, nesses casos, retirar uma das peças, adotar ou se doar tanto, romperia com a cadeia que a leva a descompensar.

Vale chamar a atenção para o peso que Duzolina dá à intensidade dos sentimentos, com o uso de expressões como tanto, tão, bacana, monte, de um jeito, mais que a boca, que entram em contraste com o "dou (...) tudo que eu posso" no trecho anterior. A alta intensidade leva o profissional para além das possibilidades, desativa catracas e impede de "cair fora".

O verbo poder, ao mesmo tempo, reserva para si a possibilidade de ser usado tanto no sentido de o que é permitido quanto no de conseguir, o que confere um tom peculiar a essa fala. Os limites que a enfermeira coloca para si tem íntima relação com os limites que ela identifica em si.

A enfermeira perde um paciente do qual se apoderou. Atentando-se para a cena que se monta pelo discurso de Duzolina, podemos ver a mãe perdendo seu filho. É idêntico a se a enfermeira tivesse perdido o próprio filho. Por fim, a sugestão inicial colocada por Duzolina como exemplo a ser seguido parece conter a conclusão de que para não se ter a dor de perder um filho, basta não ter um.

A identificação com a mãe da criança ocorre na fala de todas as participantes, ora de 
maneira mais explícita, reconhecida como um ponto difícil de lidar, ora de maneira sutil e naturalizada. Constitui, todavia um ponto de tensão na construção do exercício profissional.

\section{A mãe}

Com fidelidade ao que anunciamos ao final da parte em que apresentamos este capítulo de análise, buscaremos mostrar neste tópico os pontos de tensão que se constituem na relação direta com a mãe da criança e o colorido que acaba por conferir à relação que as profissionais desenvolvem com seu trabalho.

A mãe é a acompanhante por excelência. Aqui usamos o termo em itálico para falar desse lugar institucional de acompanhante que esse termo traduz. Para toda internação está previsto a possibilidade do acompanhante presente em tempo integral. Sua função é oferecer os cuidados "mínimos" para os pacientes.

Rosa: porque a parte delas é troca, mamadeira...

Camila: é o mínimo, né...

Rosa: a gente é mais medicação, inalação... Essa parte, quando elas estão. E quando elas não estão a gente também faz essa parte, só que às vezes elas estão junto, mas fica meio ausente...

(Segundo encontro)

Quando a mãe não faz a sua parte, quando fica meio ausente, cria-se entre as profissionais um dilema sobre como proceder: elas devem fazer essa parte da mãe ou devem cobrar desta que faça a parte que lhe cabe? Algumas profissionais escolhem a primeira opção, enquanto outras a segunda. Como vimos ${ }^{23}$, o modo como está organizado o serviço de enfermagem faz com que durante o período de internação diferentes profissionais cuidem do mesmo paciente. Caso cada um tenha um modo próprio de proceder, o conflito está lançado. Pois acontece de o acompanhante reclamar para o profissional quando prefere o modo de fazer do outro. Ao mesmo tempo as profissionais se colocam contrárias à padronização que impeça que "cada uma tenha seu jeito de trabalhar". Eis um fragmento dessa discussão, no segundo encontro:

23 Na parte 1.2 - A equipe de enfermagem descrevemos como está organizado o trabalho das profissionais na enfermaria. 
Laura: Por exemplo, eu prefiro não ir chamar a mãe no computador. Pegar, trocar a criança, dar a mamadeira e cuidar, do que ir lá chamar. Aí o outro plantão vem e fala assim "pô, mas você também faz tudo em vez de chamar ela para fazer, ela acha que eu também tenho que fazer"... Aí também tem isso daí. "Mas você coloca muita manha nas crianças..." (como que imitando alguém).

(risadas)

C: porque... Estou entendendo que... As decisões que vocês tomam no plantão de vocês interferem no plantão dos outros...

Várias: claro! Com certeza...

Martha: porque cada um tem um jeito de trabalhar também, né.

Várias: é!

Martha: não tem como... Se de repente eu faço alguma coisa de manhã, se ela vai cobrar para a menina à tarde, ela não tem que fazer o que eu fiz, né... Cada um trabalha de um jeito...

?.: É!

?.: Cada um tem seu jeito de trabalhar.

Maria: "a fulana fez o rolinho assado, e você... vai fazer como?".

(risos)

Cátia: "Pede pra fulana fazer quando ela chegar!"

Laura: é assim mesmo... Tem que ser assim, porque...

Maria: mas cada um tem uma forma de trabalhar, né...

(Segundo encontro)

A organização do próprio trabalho depende, portanto, de negociação com o "outro plantão", que são profissionais que trabalham contiguamente em momentos distintos. Em relação à conduta com as mães que não fazem a sua parte, as profissionais colocam a declaração da chefia na qualidade de algo a ser seguido e, ao mesmo tempo, mostram que alguns profissionais não a seguem.

Laura: ah, mas a gente já até ouviu da parte de chefia falar que nós estamos lá para prestar os cuidados para a criança, e que a mãe só está lá para acompanhar a criança. Você não tem direito de exigir que ela troque a fralda, que ela cuide da criança, então... (Camila vai concordando)

C: e aí se a mãe quer fazer, ela faz...

Laura: se a mãe quiser fazer, ela faz, se precisa de ajuda você ajuda, você ensina, mas você não exige.

C: ta... Tudo, daí... Vocês têm que fazer tudo...

(Segundo encontro) 
A chefia manda, mas o que ela determina mostra-se insustentável do ponto de vista da organização do trabalho. E é em tom cômico que as profissionais continuam:

Várias: tudo... Tudo...

C: e como que é?

Martha: não, só imaginar... Você está com quatro ou cinco crianças... Se todas as mães falam isso para você...

Maria: imagina... Cinco inalações ao mesmo tempo... (ri)

Martha: é... E trocar fralda de todo mundo, dar mamadeira para todo mundo...

Maria: mamadeira...

Cátia: três sem acompanhante, você já pensou?

Maria: imagina três crianças chorando, no horário de dar mamadeira você tem que dar mamadeira para as três...

Camila: é, e não é só mamadeira...

Maria: é... E fora medicação. Tipo, tem uma inalação, tem mamadeira, tem uma medicação EV [endovenosa]... E você tem que fazer nos três...

(Segundo encontro)

O número de pacientes pode ser reduzido e mesmo assim a sobrecarga de trabalho ser muito grande. O trabalho da enfermagem prevê o "trabalho" da acompanhante-mãe. Nesse sentido, apesar de ser parte da clientela, sua função não é apenas demandar e receber os serviços da instituição de saúde, mas compreende peça fundamental para que o serviço prestado pelos profissionais de saúde se concretize de modo eficaz.

Ao iniciarmos esse tópico sobre a Relação com a clientela anunciamos um lugar híbrido para a mãe. Pois aqui podemos demonstrar como ela se torna ao mesmo tempo cliente e agente institucional:

Laura: (...) Mas se você for ver, em muitos casos se você for avaliar a mãe também você não mandaria uma criança, se você tivesse um pingo de juízo. Que nem o Carlos, que mandaram entregar o menino para aquela mãe dele lá... Aquela maluca!

Maria: é...

Laura: Estava óbvio que o menino ia sofrer nas mãos dela, e mandaram.

Maria: O dia que ele saiu de alta a gente tinha certeza que ele voltaria pior... Pior não, porque ele foi bem, né? Ele voltaria em um estado crítico, e foi o que aconteceu. Ele voltou e todo mundo chorou quando viu ele... Né... E nesse caso mandaram... O Carlos, com uma mãe que todo mundo via que ela não tinha condições nenhuma de cuidar. Todo mundo sabia disso, $\mathrm{e}$ 
foi para casa com ela.

(...)

Martha: inclusive comentei, falei "se entrega uma criança daquelas, para uma mãe daquelas, então pode qualquer mãe pode... levar pra casa".

Várias juntas concordando

Maria: qualquer pessoa cuida, né?

(Segundo encontro)

Mãe ruim adoece a criança. A criança aparece como quem sofre as e nas ações também da mãe, como objeto-descuidado em suas ações.

A mãe boa é a que colabora com o trabalho das profissionais de saúde. A mãe ruim atrapalha, deixa o trabalho mais pesado:

Laura: é que a gente tem uma enfermaria com várias crianças... Se uma mãe for encrenqueira, dessas, assim, solicitantes demais, provocativas, as outras são contaminadas com esse mesmo comportamento...

(...)

Cátia: mas o contrário também acontece, né. De re-internar depois que foi para um outro hospital que foi maltratada, e depois quando vêm para cá... Percebem que está num paraíso... Que aqui é bom...

(...)

Cátia: Tem umas que aprendem, já ajudam a gente já a arrumar o berço, aí as outras também, estão vendo aquela arrumar o berço, também arrumam o berço... Não tem só o lado ruim não. ?.: É...

Maria: é, tem o lado bom também. É verdade...

Cátia: às vezes uma implica com a gente, aí uma outra do quarto gosta, vai lá e defende a gente... Então...

(Segundo encontro)

Também a relação com as mães é tecida por entre os procedimentos. Fazem parte do grupo que deixa o trabalho mais pesado as encrenqueiras, as provocativas, as solicitantes demais. Verificamos aí a proximidade entre solicitação, provocação e encrenca.

Entre fadas e bruxas, o crivo para se avaliar se a mãe é ou não boa mãe:

Rosa: e uma mãe igual a aquela assim, tanto tempo na pediatria, mantendo sempre o seu lugar, é uma coisa assim inédita... 
Alice: você nunca viu a Gabriela em um barraco.

Rosa: e ela procura até amenizar, assim, quando ela vê outras mães querendo fazer um ‘fervor' lá, ela... Com o jeito dela ela tranquiliza, e fica tudo em paz. Acho muito bonito o jeito dela, de admirar, tanto tempo aí, né, e sempre no lugarzinho dela... Ela deve assim por dentro estar extrapolando, né, mas... Mantém o seu nível, assim, seu lugar. É de admirar o jeito dela.

Maria: é verdade... Você ficar um ano no hospital, né. (...)

$(\ldots)$

Alice: foi diferente do caso da Vanessa... Da Vanessa foi diferente. Não sei, você chegou a conhecer a Vanessa, uma "Downzinha" [referente a síndrome de Down] que a mãe também era bem...

$\mathrm{C}: \operatorname{sim} \ldots$

Alice: né, sem parafuso nenhum... Então, da Vanessa foi diferente.

Laura: acho que a mãe da Vanessa era pior do que a Gabriela...

Maria: é, também acho...

Alice: a mãe da Vanessa é agressiva! A Gabriela não...

Laura e Maria: é...

(Segundo encontro)

Nesse trecho as profissionais falavam da injustiça que o Juiz fazia ao decidir separar Gabriela dos dois filhos (um deles é Pedro, de quem falaremos logo abaixo) com a alegação de que a mãe não possuía condições cognitivas e financeiras para cuidar deles. Elas comparam com o caso de outra paciente, no qual o Juiz decidiu que a guarda ficaria com a tia da criança. As profissionais julgam que a mãe de Vanessa teria muito menos condições de cuidar da filha em comparação à Gabriela. O crivo se pauta na "agressividade", no comportamento da mãe na enfermaria, se essa mãe facilita ou dificulta o trabalho da equipe de enfermagem, torna-o leve ou pesado.

Rosa nos mostra que limitar de saída as exigências da mãe é uma forma de limitar a carga de trabalho:

Rosa: (...) assim, se uma pede material para o banho, banho é rotina de manhã, mas se à tarde uma pedir uma roupinha para dar um banho, à tarde, porque está calor, se você trouxer, daqui a pouco todas do quarto vão pedir uma toalha, um saquinho, para dar o banho também. Então, a gente já fala "só em vômito, em caso de diarreia, vômitos, que dá banho fora do horário, senão não". Porque já tem que cortar logo, senão vai ter que trabalhar... Multiplicado, triplicado.

Maria: qualquer coisa que você fizer para uma sempre vai ter outras que vão... "ah, faz para 
mim também, faz para mim também...“. Sempre tem.

(Segundo encontro)

As mães aparecem como o "diapasão" de carga de trabalho das enfermeiras. Restringir o campo de exigência das acompanhantes significa mais que organizar o trabalho, é controlar a sobrecarga gerada por este. Os procedimentos são constitutivos de toda a relação.

Ao mesmo tempo e por isso, como vimos, a negociação com o "outro plantão" se dá em termos da padronização de práticas para a estabilização das relações. Por consequência ter-se-ia uma estabilização da carga de trabalho. Podemos verificar essa tensão na busca pela padronização apesar de haver um discurso contra ela, uma fala que valorize o "jeito de cada um trabalhar". As relações de poder se dão, também, em torno dos procedimentos.

Vejamos agora que para as profissionais, mãe má produz "filhos problema" e pacientes intragáveis:

Camila: tem criança que eu não gosto, não...

(...)

Cátia: tem criança que você acaba não gostando por conta dos pais

(...)

Alice: não, da criança mesmo!

Camila: então, dos pais da criança...

Alice: e da criança mesmo! Que nem aquele menino do 10, ô menino chato!

Maria: o Rogério?

Alice: "titia! ô titia!".

Laura: ah, você viu a história daquele moleque?

(...)

Laura: tem uma história complicada aquele moleque! Eu fui ler, achei que ele... Achei que ele não era normal, que era retardado...

(...)

Camila: retardado, né?

(...)

Camila: (...) brigando com o Pedro... Mostrando a língua e xingando o Pedro!

Rosa: é adotivo, daquela mãe?

Laura: não, a mãe é dele mesmo, mas a mãe tipo... aquela mãe que não é mãe... Entendeu?

Camila: não é presente...

Laura: é... Logo que ele era bebê, pequenininho, ela vivia uma série de conflitos com o pai, que era alcoólatra... Aí ela perdeu a guarda dele, ele morou numa instituição, ficou lá na 
instituição... Com 6 anos de idade uma tia tirou ele da instituição, depois a tia não quis mais, aí foi entregue para a mãe de volta... Aí a mãe arrumou outro marido, que diz também que não se dá bem com o marido... Só não separa porque não tem condições de se sustentar...

Alice: aquele moço é o padrasto do menino?

Laura: acho que é padrasto!

Alice: Gente!

(...)

Laura: ontem eu vi o padrasto dele abraçando ele atrás assim...

Camila: mas ele responde todo mundo. Indiferente...

Laura: Com a mãe... Ele é muito agressivo com a mãe... Ele tem uma revolta muito grande, né, e ele tem razão...

Camila: e ele quer ser bebê... Né?

Alice: mas é um moleque chato! Chato!

Laura: ele é carente...

(...)

Alice: Ele é muito chato!

Laura: ele é chato, mas... Ele tem razões para isso, coitado...

Alice: mas não deixa de ser chato.

Rosa: a vida deixou ele assim...

(...)

Rosa: é, então... É o que pode acontecer com Pedro, né...

(várias concordando)

Rosa: arrancado da mãe, dessa forma... Instituição, acho que é... Segundo, terceiro plano porque... Distancia, né, a família...

(Segundo encontro)

Para as profissionais, a mãe que não é mãe, é a mãe ausente. Ela aparece como alguém que não se importa com seu filho. A falta da mãe de verdade é o motivo do desalinho de qualquer criança. As mães são lugares-referência, a família por excelência. Os demais familiares - pai, tios, avós, etc. - são secundários.

A criança neste trecho aparece como sujeito-produto de sua mãe. Apesar de ser sujeito das ações, tanto ações quanto seus motivos são compreendidos como produto próprio a certo tipo de mãe.

Alice: mas isso é muito triste, essa história é muito triste.

Maria: E você pensa também no futuro dessas crianças, né, que futuro, gente? Um para cada lado, em um abrigo... E aí? 
Alice: a concepção de família foi para o espaço...

(Segundo encontro)

Quando nem os demais familiares podem cuidar da criança, a ela só resta o Abrigo. A institucionalização, na visão das profissionais, determina a separação da criança de seu futuro, é o pior dos destinos que se poderia ter. A mãe é a sede do futuro da criança.

Quando a mãe é mãe, ela é presente e não quer ver o filho sofrer. Nesta categoria está incluída a maior parte das mães da pediatria. Elas tentam burlar as regras e por isso devem ser vigiadas, controladas e, se necessário, punidas. Isso por conta da organização do trabalho e também pelo controle do paciente:

Alice: (...) Uma vez, a noite, estava dando plantão noturno, e aí ela [mãe] virou para mim... Eu entrei no quarto para examinar as crianças, o 13, e ela dando bolacha 'traquinas' para a criança, falei “mãe, não pode...”, “quem falou que não pode! Eu vou dar mesmo!”, falei “a senhora já está deitada, não pode dar bolacha 'traquinas' para a criança. Eu vou sair, na próxima vez que eu entrar não quero ver mais essa bolacha mais." Ela esfregava assim na minha cara, esfregava é modo de falar, mas sabe quando você sente até o ventinho da embalagem, assim, no nariz?

C: e aí?

Alice: e aí eu sai... Ela começou a gritar comigo. Aí foi nessa hora que eu falei que eu não era surda, que não sou deficiente auditiva. Aí eu sai, aí a Cláudia entrou. Aí a Cláudia desceu o sarrafo nela também. Aí depois ela veio pedir desculpas.

C: a tá... E não podia comer bolacha 'traquinas'...

Alice: não pode porque assim, você imagina... Uma criança come. Se tem uma criança diabética lá... Como você vai explicar?

C: tá...

Duzolina: se ele come a bolacha 'traquinas' fora de hora, daí não vai comer a comida que tem que comer... Aí você perde todo o controle... Da criança. Daí o médico vai lá "ah, vamos botar soro porque não está comendo". Só que você não ta sabendo que está comendo 'Danoninho', bolacha 'traquinas', 'Coca-Cola'...

Alice: 'miojo'...

Maria: às vezes tem uma diarreia e às vezes é por causa do que comeu que trouxe de casa, entendeu?

.?.: Uhum... Você fala, "mas estava tudo normal!".

Maria: Um 'Danone' que estava fora da geladeira, alguma coisa assim, comeu, teve uma diarreia e a gente fica meio sem saber o por que, mas...

Duzolina: daí que cai em cima "não, mas quem que não lavou a mão? Teve diarreia porque?" 


\section{Vai cair em cima da enfermagem.}

Alice: aí a chefe cai em cima da gente.

C: e explicar isso para a mãe... Não adianta?

Maria: não, elas são orientadas. Quando entram no hospital já são todas orientadas, mas mesmo assim elas não... Elas tentam burlar as regras... (risos)

Alice: mãe é mãe, né, Ronaldo... Não pode ver um filho sofrer, né...

Maria: é lógico que assim... Tem crianças, tem muito tempo, teve um menino que ficou muito tempo com a gente, que ele até pedia outras... Outras coisas para a nutrição, e a nutrição até tentava, né? Fazer as coisas assim que ele pedia... Porque já esta há um tempo estendido... (...)

(Terceiro encontro)

A imagem que podemos formar é a do hospital como a caixa hermética na qual todos os movimentos do paciente são monitorados e controlados, dos fisiológicos aos comportamentos. Qualquer alteração, entradas e saídas devem ser registradas com vistas à manutenção da assepsia e fidelidade no monitoramento do quadro clínico do paciente. À equipe de enfermagem cabe essa função de vigiar, controlar e castigar.

À mãe cabe cooperar, obedecer às regras e se desculpar quando comete uma infração. Na conversa com a mãe, esta aparece agressiva, ao passo que Alice se posiciona de modo aparentemente doce. A discrepância chama ainda mais a atenção quando Alice refere que “Cláudia desceu o sarrafo nela também”. Cabe dizer que Cláudia é enfermeira.

O controle do paciente se faz pelo controle da mãe.

Segundo vimos acima, o tempo estendido de internação de pacientes, ou o seu retorno constante, faz com que se tornem exceção às regras de funcionamento do hospital e de funcionamento da relação desenvolvida com as profissionais. O paciente se torna especial.

Maria: No plantão passado teve um caso que estava um pai e uma mãe um em cima do outro, no colo...

Duzolina: ah! É verdade...

Maria: né, você está num ambiente hospitalar, aí senta o pai numa cadeira e a mãe no colo dele e ficam lá deitados... Chega num quarto com um monte de outras crianças e outras pessoas... A Duzolina entrou no quarto, pegou a cadeira e falou assim: "olha, um senta aqui e o outro ali, os dois assim eu não quero mais".

Duzolina: eu falei “olha, nós estamos num hospital, estou trazendo uma outra cadeira para você sentar, e você por favor levanta, porque essa cadeira é para aguentar uma pessoa só. Então você levanta, você senta aqui e você senta aqui... vocês decidem quem que vai sair tá bom? Muito obrigada, estou aguardando vocês levantarem". E saio do quarto e fico olhando... Aí eles 
percebem a minha presença. Aí eles ficam incomodados "não, não, já estou saindo", aí eu falei "então tá, muito obrigada". Aí levantou rapidinho. Então você não dá chance para a pessoa argumentar...porque se argumentar você...

Alice: é! não tem que dar chance não!

Duzolina: então, coisas assim... Que te colocam em saia justa, você já tem que chegar decidida.

C: uhum...

Duzolina: né? Então... Aí até a (?) falou, né? "nossa, quando eu crescer eu quero ser assim, chegar lá e resolver...” Mas assim... Às vezes não funciona, né...

C: ahm...

Duzolina: que nem quando uma mãe... Esse mesmo dia, né, teve o problema dessa mãe, uma outra mãe pegou no colo uma outra criança. E eu falei "olha, você está acompanhando a sua filha, você vai ficar com a sua filha", "ah, mas eu sou prima dela", falei "tá, mas aqui você é mãe da fulaninha, então você não vai pegar o filho do outro, vocês estão em alas diferentes e você não está aqui para cuidar do filho do outro. Quem está cuidando do filho do outro?", "ah, a mulher que está lá do lado", "então, ela vai ficar", "ah, mas ela está estranhando", aí eu falei “então, ela está estranhando, ela não pode ficar aqui", peguei a criança no colo, "não, não, mas vamos ficar". Daí a que estava no colo falou assim, falou para a outra "é, deixa virar as costas que eu vou pegar ele no colo", olhei bem pra cara dela, eu falei assim "se você pegar ele no colo novamente, eu já te orientei, aí nós vamos conversar diferente". Ela me olhou assim com uma cara e eu falei "Eu não estou brincando. Espero que você respeite as regras do hospital. Para o bem da sua filha e para o bem do menino. Estamos entendidas?", aí ela saiu batendo perna mas... Obedeceu, né. E aí a gente ia sentar para conversar diferente, né...

C: mas essa deu certo...

Duzolina: deu! Geralmente dá certo.

(Terceiro encontro)

Duzolina diz que, após contar a história de sucesso da intervenção para a manutenção do bom funcionamento do hospital, contará a história que "não funcionou". Considerando que a segunda história também deu certo, verificamos que não está previsto a orientação não ser seguida.

Duzolina fala de dois momentos: no primeiro a orientação é acatada "rapidinho", e isso lhe rende o reconhecimento de força por parte das colegas; no segundo a acompanhante resiste à ordem dada pela enfermeira, (im)posta em nome das regras do hospital. Neste caso, torna-se necessário o uso de outras armas. A ameaça ao bem dos pacientes é então lançada contra a acompanhante. O tom ameaçador carrega a ambiguidade. Na ação mesma da 
acompanhante poderia haver uma conduta que colocasse em risco o bem da criança. Mas também poderia ser a ação punitiva da enfermeira que levasse a esse risco. Num ou noutro caso a responsabilidade pelo "risco" recai, por fim, sobre a acompanhante.

A enfermeira nos mostra que não está previsto negociação. A decisão sobre a conduta é tomada previamente. A ação possível à acompanhante é acatar, ou se responsabilizar pelos riscos do desacato. Neste terceiro encontro não há relato de inversão nessa relação de poder, ou seja, de as profissionais reverem a ordem dada. Com a líder não há escapatória para as mães.

No segundo encontro, e a ele Duzolina não comparecera, as profissionais relatam cenas nas quais se sentem reféns das mães "violentas":

C: (...) e como que é lidar com uma, por exemplo, uma mãe violenta?

.?.: Hum... É difícil!

Laura: É... É complicado, porque você não se sente amparado...

Camila: você só tem que acatar, você não pode reagir, entendeu?

Laura: é cobrado que você tem que ter uma postura, que você tem que colocar limitações na mãe, mas você não tem... Ferramentas para isso...

Maria: você tem meio que entrar no jogo dela. Né? Do jeito que ela está falando você tem que aos poucos, sendo maleável, conseguindo as coisas... Porque...

Rosa: aí quando elas vão para o computador, você vê que ela está lá, você pega e dá mamadeira para a criança, troca a criança... Porque tem umas que mesmo lá acompanhando, dão uma abandonada na criança, e aí a gente acaba cuidando da criança porque... Não é suficiente para cuidar.

Maria: ao mesmo tempo em que a gente chama a atenção, a gente tem que criar uma forma da pessoa não interpretar aquilo como uma coisa...

Camila: uma cobrança...

Maria: é, uma cobrança... Entendeu?

Laura: porque se isso gera um conflito entre você e o acompanhante você é chamada a atenção, porque você não deveria ter afrontado... "você não está lá para ensinar, você não está lá para cobrar, você não está lá para isso". E ao mesmo tempo em que se você assume as crianças e deixa lá a mãe fazer o que quiser, aí é te cobrado também que "você precisa ter uma postura mais firme com a mãe..."

Uhum...

Maria: exatamente...

Laura: de fazer ela cuidar da criança... Aí fica complicado, né.

.?.: eu já prefiro largar de lado. 
Camila: é, você não tem respaldo nenhum, né..

Maria: é... tem certas, certas situações, certas mães que às vezes é melhor a gente cuidar do que...

Camila: cobrar...

(Segundo encontro)

Lidar com as acompanhantes é terreno arenoso para as técnicas e auxiliares. Note que Alice, a única enfermeira presente no dia, não se coloca nessa parte da discussão. Ao grupo de técnicos é vetado o confronto. Um conflito com a acompanhante se desenrola num conflito com a chefia (supostamente). Diante do desamparo sentido em relação à chefia, as técnicas valem-se de estratégias como a sedução e o "drible" no jogo com as mães e mantém como alvo o cuidado com o paciente. Mais uma vez, em especial no discurso de Rosa, a criança aparece como objeto-alvo do trabalho. A mãe aparece como sujeito das ações e, na cena, só atrapalha, ajuda apenas quando abandona.

O trabalho da equipe de enfermagem parece se desenhar em cuidar da vida do paciente e cobrar da mãe o cuidado com a vida do filho. Para tanto, cuidar, controlar ou vigiar as atitudes das mães, faz parte do trabalho. Há uma tensão entre cuidar do paciente e cobrar cuidado da mãe. A situação exige do técnico de enfermagem criatividade, para a qual muitas vezes se vê impedido, dado seu lugar institucional; exige do enfermeiro, por outro lado, postura firme, autoconfiança, liderança.

Podemos perceber aqui que, para as profissionais, realizar os procedimentos originalmente previstos para serem realizados pela mãe, passa a ser assumir o papel da mãe, o seu lugar. Há certa (con)fusão entre fazer e ser. A não distinção nos procedimentos carreia a não distinção na relação. Nesta (con)fusão podemos enxergar a marca de uma produção possível do entrelaçamento entre procedimento e relação.

Não basta, contudo, ser mãe presente para se garantir uma mãe boa o bastante, na visão dos profissionais de saúde. É o caso de mães com pouca instrução, baixa escolaridade ou abaladas psiquicamente:

Alice: igual ao menino que acabou de chegar lá, internar lá... Esse vai ser outro...

(...)

Alice: ele tem um tumor que ninguém explica...

Martha: renal... 
Alice: um tumor renal. Já vai para 'quimio', para tudo... A mãe você vê que a mãe está mais perdida do que cego em tiroteio...

Camila: e por que que internaram aqui?

Alice: porque não tem vaga no Hospital $D$.

Maria: ah, mas quando surgir vai para lá, né...

Martha: e ela estava meio brava, ela falou assim "o médico falou que não era para vir pra cá".

Porque aqui eles não tratam isso.

(várias juntas)

?.: É... Eles não entendem!

Maria: é... Exatamente.

Martha: e ele fez um xixi com sangue, até com coágulos! Agora...

(...)

Maria: bebezinho?

Alice: bebê... Não chega há ter um ano.

Laura: será que não é um abcesso?

Alice: é tumor. É tumor porque já vai para a 'quimio'.

Camila: aí trouxe para cá e ninguém sabe a conduta e fica aquela coisa...

Maria: é, para cá não adianta trazer...

(...)

Rosa: será que no PS [Pronto Socorro] lá, será que não atendia?

Alice: eles não têm PS.

Rosa: não tem ambulatório?

Martha: diz que ela podia ir no PS do Hospital E....

Camila: é...

Maria: é, devia ter ido para o PS do Hospital E...

Alice: Discute, né! (Inaudível)

Camila: é... Porque lá é mais fácil deles encaminhar...

(...)

Alice: essa vai ser outra novela...

Maria: porque na verdade ele vai ficar aqui até surgir uma vaga lá...

(...)

Laura: aqui eles vão mandar dar dipirona e paracetamol intercalado

Maria: aqui, aqui vai ficar fazendo nada. Vai ficar esperando surgir vaga lá... É complicado...

(Segundo encontro)

Na situação relatada o paciente é um bebê.

O Hospital-Escola apresenta limitações para o exercício de sua função terapêutica. Neste caso, torna-se um lugar de espera... Onde se desenvolvem cuidados paliativos. Os 
cuidados não terapêuticos são compreendidos como nada.

A limitação do Hospital-Escola, e quiçá do sistema de saúde, é colocada como limitação da mãe, que não entende, que deveria procurar outro hospital, outro Pronto Socorro... Os hospitais não são todos iguais e, assim, a mãe que sabe e tem a iniciativa de procurar aquele mais adequado ao tipo de tratamento necessário tem mais chances de salvar o filho. No contraponto, uma mãe perdida tem mais chances de perder o filho.

Confiar nos trâmites institucionais do sistema de saúde é estar perdido. A saída apresentada pelas profissionais é sair. Paradoxalmente, a mãe orientada encontra-se nas brechas que burlam a burocracia do sistema.

Por fim, ser mãe é ter sob sua responsabilidade toda a vida da criança, o que implica a geração e manutenção, mas também a própria morte do filho.

\subsection{A relação com os outros profissionais}

\section{Fazer viver e deixar morrer}

Alice: É. A gente estava lá, eu fiquei do lado de dentro, ela ficou do lado de fora da enfermaria, cuidando (...) uma criança neuropata, eu ficava lá dentro "Paulo faz isso, faz aquilo" e chamando... Aí quando a menina parou... Aí você tem que, alguém tem que estar lá para auscultar para ver se parou mesmo, né? Aí você fica assim... Você vai lá, você ausculta e você pega e... O não verbal da gente é aparente! Você pega e, acho que deve o olho cair, sei lá, não sei como é que funciona. (...) você não pode falar que é mentira, "mãe, eu não posso mentir para você"” (...) eu passei por isso também no estágio, que eu fiz estágio voluntário (...) com adultos. E assim, as enfermeiras eram muito sacanas, elas sempre colocavam você com os piores pacientes, os mais lascados para você cuidar. (...) Aí eu fiquei com ela, só com ela, falou assim "não, você vai ficar só com ela, para não precisar ficar com outra pessoa”, e ela morreu na mão de quem? Na minha. Aí falei "saco!" Aí chama o médico para atestar, ele não pode subir e "ausculta e fala que está sem ausculta", (...) Eu senti assim. Fiquei assim, sem reação, porque... Como que eu ia mentir? E tinha parado... É essa onipotência de você ter que falar, de dizer "morreu e não posso fazer nada" que, se eu colocar aquele 'esteto' lá ela vai viver de novo? 
O profissional gostaria de poder mentir, mas a mentira lhe é vedada. Ele deve estar, de corpo inteiro, do lado da verdade. Onipotência e impotência se invertem no discurso de Alice. Não ser capaz de ressuscitar os pacientes "com o estetoscópio", e também ter que comunicar a morte de um paciente, não a torna onipotente, ao contrário, a submete às regras do hospital e às leis da natureza, a torna impotente.

Ao mesmo tempo, em outro momento Alice também utiliza o termo de maneira invertida. Vale ressaltar, então, que quando ela se diz "onipotente" ela está realizando uma ação que compete ao médico. Cabe ao médico atestar o óbito, mas naquele momento quem "tem que falar" é a enfermeira. O termo onipotente está ligado a um lugar institucional que compreende a expectativa do exercício de uma série de ações por aqueles legitimamente habilitados para tal. Este lugar é o de médico.

A relação com os outros profissionais não enfermeiros também se dá em meio a procedimentos. Cuidar dos piores pacientes, ficar responsável por eles, é visto como sacanagem. O paciente está "na mão" da enfermeira. A possibilidade de morte faz do paciente uma espécie de batata-quente. Quando o paciente morre no turno da pessoa, isso é sentido como uma falta de sorte somada à sobrecarga de ter de dar conta sozinha: "manda chamar o médico pra atestar", "ele não pode subir". O profissional de enfermagem está sozinho, se sente sem reação, submetido e, já vimos, paradoxalmente onipotente.

Sobre potência e impotência, sigamos o discurso de Alice e Duzolina:

Duzolina: É, e o problema são os pacientes que você não investe. Porque se você faz tudo o que você pode, você investe, faz massagem, entra com droga, tarará, tarará... Você sabe que você fez o que você podia. O problema são os pacientes de "se parar parou". Você não vai reanimar...

Alice: só que sempre tem um Cristo que vai lá e reanima...

Duzolina: então... É difícil...

Alice: e geralmente é assim...

Duzolina: Porque a mãe sabe que, se parar, parou. Não vai fazer nada...

Alice: a gente sabe..

Duzolina: A gente sabe, mas... É ruim. Você fica naquela, né...

Alice: sempre tem o Cristo que vai lá e reanima. Porque geralmente é o Cristo que está comandando a parada...

C: o Cristo seria...

Alice: o cidadão que comanda a parada, que... “ah, faz isso, faz aquilo, faz aquilo outro...” e é 
sempre o Zé Mané que está comandando a parada que é que investe! Que não tem que investir! Já tem o negócio documentado, está documentado no prontuário, fez, foi feita reunião com a equipe, foi feita reunião com a família... E ele vai lá e investe.

C: então, nesse caso seria o médico assistente...

Alice: uhum...

C: ou um residente..

Alice: um residente...

C: ou o residente.

(Primeiro encontro)

Existem duas "categorias" de pacientes: os que "você investe, entra com droga, faz tudo o que você pode"; e os de "se parar parou, você não vai reanimar". O conteúdo da fala das participantes mostra o "cidadão que comanda a parada" passando por cima da decisão que a equipe tirou em reunião entre si e com os familiares, é ele quem desorganiza o trabalho e o cuidado na decisão que a equipe se dedicou a realizar. Isso o torna, ao mesmo tempo, Cristo e Zé Mané, na (des)qualificação de Alice. A decisão que categoriza os pacientes e protocola os procedimentos que serão realizados é pensada pela equipe de saúde e familiares, supostamente a melhor escolha de cuidado para aquele paciente. Alice condena com veemência a ação que contradiz a decisão de equipe e fere o protocolo. Contudo, essa ação é possível.

Segundo podemos perceber, há certa organização nas relações de poder que possibilita isso. E essas relações se dão em termos de procedimento. "Comandar a parada" é função que compete ao médico, independente da hierarquia na instituição. Ele pode, inclusive, contrariar decisões de equipe e familiares no exercício da função. Vale pontuar que é possível verificar que para Duzolina a dificuldade parece se encontrar em lidar com os pacientes de "se parar parou" porque "não se fez tudo o que podia". Para Alice, entretanto, o problema parece se ligar mais à quebra do protocolo e deslegitimação do acordo, resultando na desorganização de todo o processo, inclusive de luto, por parte da mãe. Para Duzolina a dificuldade é lidar com a (im)potência diante da vida e da morte; para Alice a dificuldade está em lidar com a (im)potência na relação com os médicos.

Vejamos o que Laura nos tem a dizer:

Laura: (...) como às vezes acontece da criança ter um prognóstico muito ruim e eles colocarem a mãe para decidir "quer que a gente investe ou quer que deixa ir a óbito?" Eu acho isso um 
absurdo do cúmulo! Falar para uma mãe decidir uma coisa dessas... Eu acho que não existe isso! Eu acho que nunca mais você consegue lidar com, com o fato de você ter escolhido pelo óbito do seu filho... E ao mesmo tempo que você escolhe que invista, você vê ele lá ligado num aparelho...

(Primeiro encontro)

Pelo discurso de Laura podemos perceber um movimento no sentido de tentar retirar, ou pelo menos amenizar a situação de sofrimento da mãe. A forma de fazer isso, acredita-se, seria retirando-a dessa situação de precisar escolher. O profissional de saúde decidiria pela vida ou morte de uma criança para poupar a mãe dessa terrível decisão. Tirar da mãe o poder de decisão é considerado uma atitude de cuidado com a mãe. Laura está, aqui, identificada com a mãe, e não com o profisssional. Este, inclusive, é o polo oposto da relação, polo este no qual Laura não se inclui. O pronome eles enfatiza essa separação. Cabe, ainda, comentarmos a oposição entre investir e não investir. Aqui, investir se liga a "ver ligado a um aparelho" e não investir a "deixar ir a óbito". A decisão está polarizada entre estas duas possibilidades e a questão colocada é fazer viver ou deixar morrer. Eis a sequencia da discussão:

Alice: é querer se exonerar da culpa, né...

C: então, mas... Aí faria o que? Em vez de perguntar para a mãe, no caso...

Alice: boa pergunta...

Duzolina: eu acho que não, não teria que ter essa opção: perguntar para a mãe se ela quer ou não. Você vê as condições da criança...

(várias juntas nesse ponto)

Laura: eles que tem o conhecimento, eles tem muito mais conhecimento científico, mais, sabe... Tudo... Eles tem mais condições de decidir...

Martha: a parte médica assim...

Duzolina: acho que eles tinham que ver a qualidade de vida da criança, o prognóstico, o que que vai ser...

Alice: a qualidade de vida da família...

Duzolina: da família, e decidir se vai investir ou não. Né? Que não adianta investir e a criança ficar num aparelho, dependendo da família, se enchendo de feridas e... Vegetando em cima da cama...

Laura: às vezes a família tem vontade, mas não tem condições... Financeiras e psicológicas de lidar com aquela situação... É difícil! Eu acho que... Teria que ter outra maneira de decidir isso mesmo..

(Primeiro encontro) 
Alice prossegue na acusação aos profissionais que deixariam a decisão para a mãe com o objetivo de se exonerarem da culpa que seria deles. Alice também não se inclui entre esses profissionais. A culpa aparece como algo inerente à decisão. Culpa e responsabilidade parecem estar (con)fundidas naquele que decide. O eles, aqui, ganha um contorno um pouco melhor. São aqueles que "tem muito mais conhecimento científico", "a parte médica". Duzolina é a única que se utiliza do pronome você, mas logo o abandona e utiliza o eles no lugar. Eles é que deveriam decidir, é a eles que cabe o poder de decisão e, por consequência, a culpa. Laura é categórica no início "não teria que ter essa opção", e no final se coloca na posição de quem reconhece a dificuldade da situação.

Para as profissionais, a decisão de investir deve levar em conta a avaliação científica. Tal avaliação deve considerar condições clínicas do paciente: qualidade de vida e prognóstico; e também as condições clínicas e sociais da família: condições psicológicas e financeiras. A família aparece como quem não tem condições de decidir e à sua decisão, que não é científica, se liga a "vontade". A racionalidade científica deveria, supostamente, proteger e acolher as emoções maternas; pautar a decisão sobre o investir ou não investir para além da questão da vontade, circunscrevendo-a no perímetro da avaliação das condições. Com tais objetivos, a racionalidade científica confere menoridade ao direito materno. Estamos nos referindo ao caráter jurídico de menoridade. Uma vez que a mãe é completamente desautorizada em seu direito por julgar que ela não está apta a tal. Ao mesmo tempo, confere poder quase absoluto aos que detém "o saber científico", e aqui parecem ser profissionais que não as enfermeiras e técnicas de enfermagem.

De vez que as relações de poder se dão em meio a procedimentos, aqueles que os controlam se fazem soberanos.

\section{E no plantão noturno...}

No plantão noturno a tensão na relação com os médicos parece ficar mais acirrada:

C: então, dependendo do horário que você trabalha...tem...

Maria: vai ter mais ou menos informação... (risos)

Rosa: de manhã é mais bem informada, à tarde é mais ou menos...

Maria: e à noite é sem informação... 
(..)

Camila: é que são rotinas diferentes...

Alice: são.

(...)

Maria: de manhã tem mais pessoas tumultuando a unidade...

Alice: nossa! É um inferno...

Maria: à tarde tem menos, e à noite não tem ninguém.

Camila: à noite não tem ninguém, é mais sossegado mesmo...

Alice: à noite é mais tenso, né. Porque se não tem ninguém...

$\mathrm{C}$ : como assim mais tenso?

Camila: não tem aluno. Não tem estagiário. Não tem...

(Segundo encontro)

O plantão noturno se caracteriza pelo negativo. No noturno "não tem". Em meio a nada e ninguém, a tensão se faz presente. Alice responde ao coordenador:

Alice: se não tem médico, você acaba respondendo até pelo residente. Porque se o residente for novo e não sabe, aí você, você "oh, eu, se fosse você fazia assim. Se eu fosse você fazia assado. Desce na UTI. Faz assado... Você não vai fazer nada? Essa criança está piorando... Não sei o que...” entendeu? É você, você, e você! Aí quando você toma uma conduta vai para o raio do tal do fórum e "ah, aquela enfermeira (inaudível) de madrugada... aquela enfermeira toma conduta... aquela enfermeira não sei o que...”. Então, quer dizer, deixa morrer, né!

Martha: é.. Por aí...

Maria: é...

Alice: quantas vezes a gente não vai parar na...

(Segundo encontro)

Para Alice há distinção entre residente e médico. O que nos conta é uma situação limite. O residente não sabe, é inexperiente, ocupa o lugar de quem define a conduta (um médico) e, por isso, deveria saber. Já a enfermeira que sabe, devido à sua experiência, ocupa o lugar de quem apenas deve executar e, por isso, não deve decidir. A hierarquia da equipe de saúde supõe médicos detentores do saber, que mandam, e enfermeiros obedientes e confiantes no médico da equipe. Alice nos mostra que no dia a dia, ou melhor, no noturno, não ocorre assim. A tensão do plantão noturno se matricia na tensão política gerada pela divisão hierárquica do trabalho no encontro com a tensão entre a vida e a morte de um paciente. A resistência aparece do lado da vida. Para fazer viver é necessário burlar as regras 
institucionais.

A conduta insubordinada do profissional de saúde pode salvar a vida do paciente, mas também pode colocar em risco o seu exercício profissional mesmo se a insubordinação obtiver resultado positivo. A enfermeira se arrisca ao fazer viver e se protege ao deixar morrer. As relações de poder junto aos médicos se exercem em meio aos procedimentos que fazem viver e os que deixam morrer. A resistência é, literalmente, um caso de vida e morte.

Em meio ao dilema ético, o problema político da organização do trabalho é decidido no tribunal de justiça, quando quem é julgado é o polo mais fraco da relação, é quem não se submeteu à organização hierárquica da divisão do trabalho. $\mathrm{O}$ médico negligente não aparece como quem pode ser julgado, a não ser por elas mesmas. O profissional de enfermagem está completamente desautorizado a "tomar conduta". O desamparo está dado do início ao fim e é produzido institucionalmente.

Vejamos como a burocracia torna viva essa divisão no poder:

Martha: tem gente que não gosta de ser chamado de madrugada...

Alice: não gosta! E a gente que tem que se virar. E você acaba tomando conduta, "Faz isso. Faz aquilo." porque... Você que faz, senão a criança se dana!

C: uhum... E à noite fica um residente?

Alice: dormindo!

Várias: é....

Laura: é, ele fica até meia noite, uma hora e depois vai dormir... E a gente não pode ir lá na UTI chamar um assistente.

?.: não...

Laura: tem que chamar ele, para ele ir chamar o assistente! Em uma emergência assim... Imagina uma situação que você tem que tomar uma atitude ali no momento, ali... Você vai esperar alguém chegar? Você vai ter que fazer.

Maria: ir lá acordar o residente... "acorda!” (ri)

(Segundo encontro)

A situação é limite. Nela, cabe somente ao residente decidir se precisa ou não do auxílio do supervisor para "tomar a conduta". Chamar o médico assistente sem antes chamar o residente significa descumprir o protocolo. Supõe deslegitimação do poder de médico conferido ao residente.

Podendo chamar o residente ou o assistente, o profissional opta por uma terceira escolha. Descartadas de pronto ambas as possibilidades, o enfermeiro assume o lugar de quem 
"toma a conduta", de quem decide, e não o de quem obedece. No exemplo narrado pelas profissionais, a decisão de chamar o residente equivaleria à de decidir por deixar morrer. É como se o próprio contexto colocasse o profissional de enfermagem não mais na posição de quem obedece, mas sim na de quem decide. Na situação limite, estão suspensos os limites que definem a prática dos profissionais de enfermagem.

Mas a burocracia que visa limitar o poder de ação dos profissionais de saúde pode também funcionar como instrumento para limitar o amplo poder do médico:

Rosa: lembrei da Ariadne aqui agora. Ela era uma criança que era caso fechado, "se parar, parou"... Estou imaginando, assim, se tem um residente só, então quem cuida? O técnico de enfermagem? E a enfermeira, no caso? Nesses casos fechados?

Alice: "parar parou" eles fazem, eles... Falam que é "se parar parou" mas sempre acabam fazendo alguma coisa.

Rosa: é... Um sedativo...

Alice: sempre faz! Nunca é o "se parar parou" oficialmente e não faz nada. Sempre tem alguém que vai fazer uma massagem, sempre tem alguém que vai fazer uma droga, sempre tem. Aí você tem que chamar ele e "oh, está feita a documentação? Foi feita? Não é para fazer nada... É para dar medida de conforto..."

(silêncio na sala)

Alice: geralmente, se você já está mais experiente, mais habituada, isso a gente já vai fazendo... Esperando chegar, entendeu? Que isso a gente pode fazer...

(Segundo encontro)

A fala de Rosa denuncia a imagem que formam dos residentes: "se tem um residente só, então quem cuida?’. Alice parece ter certa clareza de que se trata de um problema político. A tensão é no que se pode e o que não se pode, o que se deve e o que não se deve fazer. A documentação (supostamente a que se refere aos pacientes que entram em cuidados paliativos) torna possível a argumentação às profissionais mais experientes. $\mathrm{O}$ documento é um instrumento político, neste caso, a favor das enfermeiras.

\section{O futuro a quem pertence?}

Na parte em que tratamos da relação com a clientela, em particular na relação com as 
mães, vimos que as profissionais de enfermagem avaliam as mães. Pudemos entrar em contato, também, com a forma segundo a qual elas realizam essa avaliação. No trecho abaixo as profissionais estão falando de duas mães: Gabriela, mãe tida por boa mãe, que facilita o trabalho das enfermeiras; e a mãe do Carlos, "que faz o menino sofrer". A avaliação das enfermeiras difere da avaliação feita por outros profissionais:

Laura: é... Sempre o final é difícil. Que nem, eles não querem mandar as crianças para casa com a Gabriela, porque a Gabriela não tem condições de cuidar das crianças, por uma avaliação que foi feita. Mas se você for ver, em muitos casos se você for avaliar a mãe também você não mandaria uma criança, se você tivesse um pingo de juízo. Que nem o Carlos, que mandaram entregar o menino para aquela mãe dele lá... Aquela maluca!

Maria: é...

Laura: Estava óbvio que o menino ia sofrer nas mãos dela, e mandaram.

Maria: O dia que ele saiu de alta a gente tinha certeza que ele voltaria pior... Pior não, porque ele foi bem, né? Ele voltaria em um estado crítico, e foi o que aconteceu. Ele voltou e todo mundo chorou quando viu ele... Né... E nesse caso mandaram... O Carlos, com uma mãe que todo mundo via que ela não tinha condições nenhuma de cuidar. Todo mundo sabia disso, e foi para casa com ela.

Laura: era muito pior que a Gabriela aquilo!

Martha: inclusive comentei, falei "se entrega uma criança daquelas, para uma mãe daquelas, então pode qualquer mãe pode... levar pra casa"

Várias juntas concordando

Maria: qualquer pessoa cuida, né?

(Segundo encontro)

As avaliações e decisões judiciais são contestadas. Quem decide (o Juiz?) não tem juízo. Vale ressaltar a indefinição desses "agentes judiciários” e que não se esclarece, que em nenhum momento ganha o contorno de um lugar institucional definido. As ações judiciais fazem pacientes e profissionais sofrerem. Quem decide não tem condições de verificar o evidente, na concepção das enfermeiras:

C: e por que ele foi com ela? [mãe do Carlos]

Alice: decisão do Juiz...

Maria: porque o juiz determinou...

C: ah, porque o juiz...

Camila: deu a guarda para ela. 
Laura: acho que é sempre assim, o mesmo procedimento: o serviço social comunica, né, o caso, aí eles lá avaliam e tomam a conduta deles. Mas eles estão só lendo lá o que que está acontecendo, assim, eles não vão verificar...

Martha: não conhecem nem o paciente nem o acompanhante, né?

Laura: é...

Maria: escrevem que a casa dela não tinha condições de higiene nenhuma... Sem condições de higiene... Como que manda uma criança no estado em que o Carlos se encontrava pra uma casa nessa situação?

Martha: eles escrevem... Escrevem da criança... Mas a mãe acho que nem [inaudível]

Rosa: se perguntassem pra mim eu ia falar "deixa tudo, tudo juntinho"... Não separaria nada...

(...)

Martha: eu acho que ela tem condições de ir pra casa!

(várias concordam)

Maria: eu acho!

Laura: se você não consegue fazer nada melhor, deixa na situação deles então... Vai interferir para piorar?

Rosa: mas a gente não tem voz, assim... Essas coisas não faz parte... Da gente...

(Segundo encontro)

A relação das profissionais da enfermagem com os profissionais do judiciário aparece em meio a processos de avaliação e julgamentos, de um lado e de outro.

Os profissionais do judiciário também "tomam conduta": avaliam, julgam e definem procedimentos para pacientes e suas respectivas famílias pautados em relatórios. Todos esses profissionais envolvidos são, por fim, julgados pelas participantes do grupo. Eles aparecem como quem pode fazer algo pela criança, pelo seu futuro, pela sua família, mas não possuem condições de fazê-lo de maneira plena. As profissionais de enfermagem, no outro polo, aparecem como quem sabe o que seria melhor, mas nada podem fazer.

O procedimento parece ser nebuloso e é contestado. É por meio dele que as profissionais de enfermagem falam da relação com esses outros profissionais. O procedimento aparece, aqui também, como o meio de relação da enfermagem com esses outros profissionais e desses outros profissionais com a clientela.

O julgamento se dá de acordo com o grau de concordância entre a avaliação do judiciário e a avaliação dos profissionais de enfermagem a respeito dos pacientes e suas respectivas mães. Ao mesmo tempo, as participantes se queixam de a avaliação realizada pela 
equipe de enfermagem não ter valor. Estão alheias a todo o processo, a elas não está previsto "voz".

A relação com esses outros profissionais se dá em termos de julgamento de "futuro":

Alice: mas isso é muito triste, essa história é muito triste.

Maria: E você pensa também no futuro dessas crianças, né, que futuro, gente? Um para cada $\underline{\text { lado, em um abrigo... E aí? }}$

Alice: a concepção de família foi para o espaço...

Maria: que nem... Em adoção, a Júlia. Você acha que alguém vai adotar a Júlia? Não vai...

Nunca. Ela vai ficar em um abrigo, o resto da vida... E assim, ela tem aquele jeitinho dela, isso a gente percebe que é falta de estímulo. (...)

(Segundo encontro)

O Hospital-Escola é entendido como lugar melhor para se abrigar uma família do que um Abrigo propriamente dito. Futuro parece significar algo próximo a felicidade, bem-estar, bem-aventurança. A cena é dramática. Se não há família, unida, não há chances de haver futuro. Mais que isso, onde há Abrigo não há futuro.

Júlia é uma paciente que tem gastrostomia e não come pela boca. $\mathrm{O}$ "jeitinho dela" se refere, supostamente, a limitações que vão além da convivência com a gastrostomia. Os pressupostos são o de que apenas crianças saudáveis têm chance de serem adotadas, e o de que "futuro" depende de família. Assim sendo para as participantes, a decisão de abrigar Júlia implica um desfecho triste da história.

Posto desse modo por nossa análise, as profissionais de enfermagem se situam entre gigantes. De um lado, profissionais que detém a legitimidade de decidir entre fazer viver e deixar morrer. De outro, profissionais que detém a legitimidade de traçar o futuro dos pacientes do Hospital-Escola. No primeiro caso, compete à enfermagem obedecer. No segundo, nenhuma participação sua está prevista. Contudo, as participantes nos mostram momentos em que elas são os profissionais mais capacitados a decidir.

Na relação com os médicos, a resistência se dá pontualmente, em situações limite, nas quais o contexto coloca o profissional de enfermagem na posição de quem decide. Em relação ao "futuro", é na avaliação que fazem dos avaliadores que elas se colocam no jogo de forças 
em torno da decisão.

Em meio aos gigantes que "tomam conduta" sobre a vida e futuro das crianças, os profissionais de enfermagem resistem. 


\section{Discussão}

A discussão será dividida em duas partes. Na primeira apresentaremos uma síntese da análise, onde poderemos retomar pontos fundamentais e colocá-los em movimento para que possamos mostrar relações que não ficaram em evidência ao tratar de cada parte isoladamente. Posteriormente, buscaremos uma discussão efetiva com outras pesquisas que se dedicaram a estudar o trabalho do profissional de enfermagem.

\subsection{Síntese da análise}

A pesquisa se desenvolveu com profissionais dos três níveis hierárquicos da equipe de enfermagem da pediatria de um hospital escola. O grupo de participantes era composto por profissionais que tinham longo tempo de trabalho no hospital que aqui nomeamos por Hospital-Escola (HE). Todas as participantes sempre trabalharam com a clientela maternoinfantil e é significativa a presença do HE em seus percursos profissionais, a fidelidade delas a esse hospital, sendo que poucas tiveram outras experiências, e relativamente curtas, além daquela.

Referem gostar do lugar onde trabalham e não desejam sair. Gostam do HE como um todo, mas principalmente da Pediatria. A relação com a Unidade está ligada à relação estabelecida com a clientela, e as profissionais da pediatria gostam da sua, se reconhecem a partir da relação com ela. O termo perfil é usado tanto para dizer da clientela quanto do profissional. Ter perfil para trabalhar na Pediatria significa desenvolver uma relação satisfatória consigo mesmo por meio da relação com a clientela. Verificamos que na pediatria os profissionais que têm o perfil para ali trabalhar tem facilitada a relação consigo próprio por meio do trabalho.

No início do grupo as participantes apresentam a expectativa de que aquele espaço as ajude de algum modo. Aparece como incerta, porém, a ajuda que poderia vir por parte do coordenador. As participantes começam apostando que suas expectativas possam ser correspondidas e a confiança, quando aparece, se liga à experiência obtida de um outro grupo que é de algum modo transferida para aquele que realizamos. O lugar inicial configurado para o coordenador é de alguém que está indubitavelmente sendo ajudado em sua pesquisa, mas que talvez não possa ajudá-las no que esperam. Não havia confiança por parte das 
profissionais em que o coordenador correspondesse às suas (delas) expectativas, quando muito uma aposta.

Nossa análise mostra a relação que as profissionais de enfermagem desenvolvem com o trabalho invariavelmente entretecida pelos procedimentos que executam. As enfermeiras, dado seu lugar, executam procedimentos predominantemente de ordem administrativa e de gestão, tais como dar ordens, organizar e dividir o trabalho, delegar tarefas e funções, grosso modo "colocar regras" para a clientela e as demais profissionais de enfermagem. Da parte das técnicas o procedimento aparece ligado mais diretamente ao cuidado com o paciente, os procedimentos "curativos", e os de caráter de organização do trabalho aparecem como resistência, como "drible", no qual as profissionais insistem em afirmar que "cada um tem o seu jeito de trabalhar". As enfermeiras, mesmo quando executam procedimentos mais diretamente relacionados ao paciente eles acontecem em meio àqueles que aqui chamamos de administrativos.

A relação entre as profissionais de enfermagem se dá em meio a aglomerações nas quais temos, por exemplo, um plantão "se relacionando" com outro, ou o grupo de técnicas "se relacionando" com o grupo de enfermeiras. O grupo se torna sujeito das ações e a particularidade de cada um e de cada situação por vezes se perde, impossibilitando a atribuição de responsabilidades. O tema da escala mensal de trabalho aparece como central. Nossa análise mostra que esse, todavia, diz de uma preocupação muito mais das enfermeiras do que das técnicas de enfermagem. Ao dominar a cena, no grupo, podemos dizer que o "problema" das enfermeiras se sobrepôs aos eventuais "problemas" das técnicas e auxiliares. Há uma divisão clara e verticalizada entre esses dois grupos no que se refere ao exercício de poder. Está previsto que as enfermeiras pensem, administrem, mandem, cobrem e punam e que as técnicas executem e obedeçam. Quando o assunto é a escala, para as técnicas a decisão é vertical e advém da enfermeira que ocupa o lugar de chefe da enfermaria, e quando ocorre problemas, estes comumente são solucionados num "acordo de cavalheiros" entre o próprio grupo de técnicos. Já no caso das enfermeiras a decisão sobre a montagem da escala costuma ocorrer em meio a uma deliberação entre os pares. A chefe da enfermaria se retira de cena e o que temos é um grupo que precisa decidir por si. Na "democracia” que se instaura verificamos uma forma de discussão bélica. Impera a lei do ganhar a qualquer custo e um desgaste considerável na relação entre as profissionais.

Em meio a essa "guerra" pudemos verificar dois movimentos. Um, do qual Alice se 
faz representante, é o de denúncia de um modo de funcionar beligerante que prejudica as relações do e no trabalho e desgasta da saúde psíquica dos profisssionais. Nossa análise mostra Alice, anunciadora do terrorismo, passando sutilmente a ocupar o lugar de quem "toca o terror". No mesmo movimento em que anuncia o incêndio, incendeia. O outro movimento, característico do lugar de chefe e que no grupo é ocupado por Duzolina, é o de extintor dos incêndios, o de apaziguador dos conflitos. O chefe aparece, mais uma vez, para "por ordem", "quando dá muita briga", "pra dar o craw". No êxito de sua função apaziguadora o discurso da chefia configura o lugar de falta de posicionamento ao modo de resistir de Alice que, inclusive, falta ao último encontro.

O coordenador mostra empenho em ajudar o grupo a resolver aquele que é apresentado como o maior problema a ser enfrentado. Nesse movimento, ocupa o lugar vago deixado por Duzolina nos dias em que ela falta. O grupo, como resposta, resiste a esse lugar assumido pelo coordenador e o desautoriza em suas colocações. Sem o reconhecimento como analista e nem como chefe, o discurso do coordenador não encontra anteparo. É deslegitimado pelas participantes.

Com a presença de Duzolina, no último encontro, e a ausência de Alice, as propostas de ordem administrativas sugeridas pelo coordenador são tomadas pela subchefe da enfermaria com entusiasmo. Verificamos a construção de um lugar de legitimidade para o coordenador como figura diferencial no processo do grupo. O lugar configurado para e pelo coordenador, por fim, passa a ser o de um bom auxiliar da chefia na execução da função extintora de incêndios e mantenedora do funcionamento institucional. As participantes, inclusive, manifestam querer a continuidade daquele grupo. Duzolina, com a frase que começa com "eu queria assim um psicólogo...", planeja inseri-lo de algum modo no funcionamento do hospital, e mais, já traça o lugar que irá ocupar, a função que irá exercer e como. O êxito do grupo é o êxito da manutenção do funcionamento institucional.

Vimos que a UTI Pediátrica se configura como o negativo da Pediatria, é onde não tem o que tem na Pediatria. E é com base nesse negativo que se configura, também, o paciente da Pediatria. Ele chega doente e sai bom após ter recebido os cuidados necessários por parte das profissionais, ele "evolui", e que quando não evolui é mandado para a UTI. Ainda na oposição com a UTI, na Pediatria o trabalho apresenta uma característica fundamental de "sempre ter o que fazer”. Mesmo quando o paciente piora muito as profissionais mandam ele para a UTI, lá se ele piora ele "vai para o Céu", como nos conta Maria. Consequentemente, no contraste, a 
Pediatria é para as profissionais um lugar mais leve para se trabalhar, com mais vida. Laura, inclusive, revela sentir pânico de UTI e nos informa, também, que mesmo quando não se quer é necessário trabalhar lá vez ou outra, situações nas quais ela sempre revive um sentimento muito forte que marcou de forma significativa a relação que estabelece desde então com a UTI. Trata-se de um episódio no qual pouco tempo foi necessário para a construção de forte vínculo e que logo foi rompido provocando intenso sofrimento. Verificamos aí uma conexão complexa entre a relação da profissional com a paciente, da profissional com o setor UTI e da profissional consigo mesma. A morte abala toda a cadeia complexa de relações.

Experiencia semelhante é relatada por Duzolina e a mesma desenvolve outras estratégias para a construção de si como enfermeira. O que preconiza é a justa separação entre papéis. Uma construção de limites que tenha por base os limites reconhecidos em si mesma. Para tanto mostra-se fundamental o auxílio da "catraca" e do "resumo de alta". Provavelmente sem se dar conta, Duzolina propõe um funcionamento subjetivo mecânico no qual o instinto e os afetos ficam do lado de fora da catraca, e para dentro teria de ser automático, desapegado e compulsoriamente movido pela circulação nas relações e espaços do hospital.

Esse modo de exercer a separação nos diz de dificuldades de base no estabelecimento de limites. Como vimos, uma série de (con)fusões são constitutivas de boa gama de relações estabelecidas pelas profissionais, a começar com a indiferenciação entre procedimento e relação que carreia a quase automática e espontânea identificação com a mãe ao realizar os procedimentos previstos para serem executados pela acompanhante, bem como a justaposição entre a relação com a clientela, relação com o setor e relação consigo mesmo. Mais propriamente na relação com o paciente verificamos a indefinição do sujeito no discurso das participantes marcando o modo caracteristicamente indiferenciado de ocupar seu lugar de profissional de enfermagem. Na relação com a mãe e com os outros profissionais verificamos a ocorrência de situações nas quais as profissionais ocupam o lugar desses "personagens" na relação com eles. Elas ocupam lugar de mãe ao se colocarem justapostas a elas no cuidado com o paciente; deslizam para o lugar do médico na emergência ocasionada por uma situação de vida e morte; julgam o Juiz e seus procedimentos de julgamento... enfim, torna obscuro os limites que determinam o seu fazer na fronteira com o de outras categorias institucionais. Como sabemos, fronteiras indefinidas são ocasião de litígio.

Diante dessa embaraçosa trama de relações a morte surge como único limite implacável, nada que se faça muda o que a define. Ela é o próprio limite... da vida, do trabalho 
da enfermagem, do que se possa fazer e, na (con)fusão, do que se possa ser.

No discurso de Laura podemos verificar que a morte não provoca a reorganização de um modo de se constituir como profissional de enfermagem, tal qual vimos com Duzolina. No lugar dessa "reorganização" temos um "trauma". Ele define a relação com a UTI como constante reencenação do episódio traumático. O trauma, a repetição, a paralisia, está no mesmo lugar em que aparece a reorganização, a reconfiguração da relação consigo mesma e com o trabalho no discurso de Duzolina.

Nossa análise configura como objeto institucional da enfermagem a manutenção e controle de todos os movimentos e alterações do e no paciente, quer sejam motores ou fisiológicos, por meio de tecnologias de monitoramento e vigilância, gratificações e punições. Desse modo, torna-se o principal instrumento a partir do qual os médicos "tomam" e executam a conduta clínica.

A mãe compreende um lugar institucional na Pediatria. Ela é ao mesmo tempo clientela e agente institucional. Ao mesmo tempo que demanda da equipe de saúde que cuide de seu filho, ou mesmo um suporte para cuidados com o filho, ela têm um papel nesse cuidado. As profissionais de enfermagem precisam da colaboração da mãe para conseguirem realizar o trabalho de cuidar do paciente, de modo que a organização do trabalho da equipe de enfermagem prevê o trabalho da mãe. Uma boa mãe é aquela que ajuda as profissionais de forma adequada, que é educada, paciente, obediente, e que facilita o trabalho da equipe de saúde, tornando-o mais leve. Isso faz com que as profissionais concluam que ela é uma boa mãe para a criança. Pelos mesmos critérios as profissionais podem concluir que uma mãe é má, e por consequência ela não é boa mãe para seu filho. Uma mãe má produz filhos problema. A relação com a mãe se dá em meio a procedimentos de enfermagem ora com caráter mais administrativo e de manutenção da ordem, que é característico das relações desenvolvidas pelas enfermeiras, ora relacionado ao cuidado ao paciente e aos procedimentos "curativos". A avaliação e classificação das mães (e não mais da mãe-lugar-institucional) se dá pelas profissionais a partir do modo como se desenvolve a relação entre elas.

Toda mãe deve ser vigiada, seja ela boa ou má, pois, como alerta Alice “mãe é mãe, né”. As boas não podem ver o filho sofrer, e por isso burlam regras e fazem com que as enfermeiras percam o controle (do paciente?). As más devem ser vigiadas e por vezes punidas, pois sua conduta é predominantemente inadequada, produz sobrecarga de trabalho ao profissional e adoecimento ao paciente. Desse modo, controlar as mães se mostra fundamental 
para a manutenção do controle sobre o paciente.

As mães são, no discurso das profissionais, como que lugares-referência para as crianças, os demais familiares são secundários. A institucionalização de uma criança é concebida como o pior dos futuros que uma criança pode ter, isto é, se ainda houver futuro possível. Para as profissionais é como se a criança já começasse a vida perdendo tudo. No discurso das participantes ser mãe parece envolver a responsabilidade total sobre a vida da criança, inclusive e no limite, a responsabilidade pela morte do filho.

Paradoxalmente as profissionais dizem acreditar que a equipe médica deveria decidir sobre a vida e a morte de uma criança sem passar pela mãe a possibilidade de escolha em casos de difícil manejo clínico, em que não há resposta satisfatória aos cuidados terapêuticos. Paradoxalmente, porque concebem o lugar de mãe atribuindo-lhe total responsabilidade sobre a vida da criança e num outro momento propõem poder quase absoluto à racionalidade científica em detrimento do direito materno com o objetivo de aliviar o peso que viria associado à decisão. Mostramos como responsabilidade e culpa aparecem (con)fundidas, também nesse ponto, naquele que decide.

A criança aparece, invariavelmente, como objeto-alvo das ações da enfermagem, das mães, dos adultos em geral, e também como sujeito-produto de sua mãe. Percebemos que com a adolescente que aparece no discurso de Laura (p. 76) há tonalidades de autonomia que não aparece quando se referem às crianças. Nos parece que para as profissionais crianças tornam-se sujeito à medida que crescem. Cada fase, portanto, possibilitaria um tipo de relação.

$\mathrm{Na}$ relação com outros profissionais verificamos a predominância de médicos e "agentes judiciários", profissionais que "tomam conduta" e frente aos quais elas resistem. Demais profissionais que trabalham no HE por muito pouco não aparecem como "mobílias" no discurso das participantes.

O jogo de poder/resistência na relação com os médicos ocorre em meio a uma polarização entre fazer viver e deixar morrer, na qual a resistência implica assumir o lugar do médico no contexto de uma situação limite, "tomar conduta" e fazer viver. Do outro lado estaria justamente a obediência ao protocolo que, segundo o discurso das participantes, implica na escolha por deixar morrer. A organização nas relações de poder supõe médicos detentores do saber, que mandam, e enfermeiros obedientes e confiantes no médico da equipe. A figura do residente, inexperiente, impossibilita a sustentação dessa lógica, o que abre 
espaço à subversão da ordem em nome da vida do paciente. Em meio ao dilema ético, não é raro que o problema político da organização das relações de poder seja decidido no tribunal de justiça.

Com os "agentes do judiciário" o jogo poder/resistência ocorre em torno da sentença sobre o futuro da criança. Esses "agentes" permanecem indefinidos e não ganham forma num lugar institucional. Sabemos que há profissionais de dentro do hospital que colaboram na construção de relatórios, que há avaliadores, que há o Juiz, mas em nenhum momento sabemos ao certo a quais dessas "pessoas" as participantes atribuem a responsabilidade daquilo, ou sobre aquilo, que falam. Todo o "processo" parece a elas nebuloso, e estão apartadas dele do inicio ao fim, sem direito a "voz". O modo como aparecem resistindo, contudo, é julgando o julgamento.

Percebemos a ironia, a deslegitimação, a denúncia e o alarde, a "falta de comprometimento", e esgarçamento de limites e fronteiras como as principais estratégias de resistência utilizadas pelas profissionais. O lugar configurado por/para Alice representa de maneira exemplar esse modo de resistir. Do outro lado, como manutenção do funcionamento institucional temos a rígida estrutura hierárquica, a punição, os processos jurídicos e administrativos e a conversa, o apaziguamento. Aqui encontramos o lugar constituído por/para Duzolina e também aquele do coordenador e do grupo analisado nesta pesquisa.

\subsection{Pesquisas envolvendo o trabalho de profissionais de enfermagem}

Realizamos uma busca por meio da base de dados do site Biblioteca Virtual de Saúde - Psicologia (www.bvs-psi.org.br) e pelo Google Acadêmico utilizando combinações das palavras "equipe de enfermagem", "hospital", "pediatria", "trabalho", "psicologia", "desenvolvimento institucional", "psicologia social". Pudemos concluir que, hoje, a maior parte dos estudos sobre o trabalho de equipes de enfermagem é realizada por enfermeiros. De todas essas pesquisas, a maioria consiste em estudos sobre processos de administração hospitalar. Outra vertente de pesquisas é a daquelas cujo foco é a relação com o trabalho do ponto de vista da Saúde do Trabalhador, examinando os processos de adoecimento orgânico, 
tendo por base e alvo os estudos de ergonomia e organização do trabalho.

Encontramos também uma quantidade considerável de estudos voltados à relação com a clientela, mãe e criança, tanto no campo da psicologia como no da enfermagem, e muitos deles se referem ao contexto de UTI Pediátrica e Neo-natal, sendo escassa a produção relacionada diretamente à Enfermaria Pediátrica.

As investigações sobre os aspectos psicológicos do trabalho de enfermagem constituem parcela pequena quando comparadas àquelas mencionadas. Nesse campo de estudo também verificamos a predominância de pesquisadores pertencentes à área de enfermagem, alguns com pós-graduação em psicologia ou administração em enfermagem; além disso, a maior parte tem como referência a Psicodinâmica do Trabalho para a realização da pesquisa. A produção por parte de psicólogos sobre o profissional da equipe de enfermagem na relação que desenvolvem com seu trabalho é escassa. Os trabalhos de psicologia realizados por psicólogos são encontrados majoritariamente voltados ao estudo da relação com a clientela, seja de seu lugar como psicólogo hospitalar, e nessa parcela de estudos está presente toda a produção acerca de avaliação e intervenção psicológica, ou mesmo buscando analisar a relação desenvolvida entre esta e a equipe de saúde, parcela de pesquisas em que encontramos foco no que a relação produz no paciente e em sua saúde, e não no profissional.

Brotta e Castro (2012) realizaram pesquisa bibliográfica semelhante à nossa, com os termos "Psicologia Hospitalar" e "Avaliação Psicológica", e apontam para um resultado próximo daquele encontrado em nossa busca. Segundo o estudo, das sete revistas que mais publicaram artigos na área três são da enfermagem, uma da saúde publica e três da psicologia. O aspecto de maior incidência nos artigos foi Avaliação Psicológica de Pacientes (43,9\% $\mathrm{N}=29$ ). O segundo foi caracterizado pelos autores como o estudo do campo psicológico sobre as práticas de outros profissionais $(21,2 \%-\mathrm{N}=14)$. O terceiro se refere à investigação de práticas dos psicólogos no âmbito hospitalar $(19,7 \%-\mathrm{N}=13)$. E os demais dizem das representações sociais frente à Psicologia Hospitalar $(9,1 \%$ - N=6) e avaliação psicológica de cuidadores e familiares $(6,1 \%-\mathrm{N}=4)$.

Das produções alocada no segundo aspecto, que nos importa para este trabalho, oito dos quatorze se referem à equipe de enfermagem. Destes, um se destina a estudar a relação entre os profissionais de psicologia e enfermagem em hospitais e cinco deles de algum modo se debruçam sobre o trabalho dos enfermeiros. 
Vejamos o quadro analítico que Brotta e Castro (2012) nos trazem referente a essas cinco publicações na página 208 de seu trabalho:

Tabela 2 - Pesquisa de artigos sobre aspectos psicológicos do trabalho de profissionais de enfermagem

\begin{tabular}{|c|c|}
\hline Aspecto & Conclusão \\
\hline $\begin{array}{l}\text { Identificação das estratégias utilizadas pelo enfermeiro } \\
\text { diante dos conflitos no ambiente organizacional. }\end{array}$ & $\begin{array}{l}\text { Para a solução de conflitos no trabalho, o } \\
\text { enfermeiro dependerá da sua postura enquanto } \\
\text { gerente, habilidades pessoais e estratégias para } \\
\text { resolução de problemas. }\end{array}$ \\
\hline $\begin{array}{l}\text { Reflexão sobre a psicodinâmica do trabalho da } \\
\text { enfermagem hospitalar. }\end{array}$ & $\begin{array}{l}\text { A equipe de enfermagem deve centralizar seus } \\
\text { trabalhos na identificação de problemas, no } \\
\text { planejamento das estratégias e avaliação de } \\
\text { resultados obtidos no hospital. }\end{array}$ \\
\hline $\begin{array}{l}\text { Análise dos conflitos nas relações interpessoais no } \\
\text { exercício gerencial do enfermeiro. }\end{array}$ & $\begin{array}{l}\text { Necessário compreender a origem dos conflitos, os } \\
\text { fatores que favorecem sua instalação e a } \\
\text { importância de abordá-los de forma interdisciplinar. }\end{array}$ \\
\hline $\begin{array}{l}\text { Estudo das relações de poder entre a organização do } \\
\text { trabalho da enfermagem e sua dimensão ética. }\end{array}$ & $\begin{array}{l}\text { Necessidade de refletir sobre o exercício de poder } \\
\text { institucional, para aprimorar estratégias de uma } \\
\text { atuação ética da equipe de enfermagem. }\end{array}$ \\
\hline $\begin{array}{l}\text { Investigação das estratégias cognitivas operatórias na } \\
\text { gestão da informação em hospitais. }\end{array}$ & $\begin{array}{l}\text { Importância da reflexão sobre os recursos } \\
\text { cognitivos em enfermeiros. }\end{array}$ \\
\hline
\end{tabular}

A organização realizada pelos autores, bem como nossa busca bibliográfica, nos mostra que a pesquisa apresentada por essa dissertação, tal qual definida com o objetivo de estudar a relação que o profissional de enfermagem desenvolve com seu trabalho partindo de uma perspectiva institucional, se faz importante para área, uma vez que apresenta uma proposta metodológica diferente. $\mathrm{Na}$ medida em que temos como referência um aporte teórico-metodológico distinto do proposto pelos estudos com psicodinâmica do trabalho, de gestão de pessoas, ou mesmo daqueles que tomam o trabalhador de forma individual e estudam suas capacidades de adaptação à organização, produzimos algo diferente como 
resultado da investigação.

A seguir, traremos para essa discussão alguns trabalhos que constroem apontamentos que julgamos interessante aprofundar e/ou confrontar a partir da análise que aqui apresentamos.

Os trabalhos que encontramos realizados por enfermeiros (Magnago et al., 2009; Peixoto et al., 2012; Souza, 2011; Campos \& David, 2011; Pinho et al., 2003) focam os procedimentos como alvo de investigação, seja na formação do profissional, na gestão do trabalho ou mesmo nas relações. O termo subjetividade, ou subjetivo, quando aparece, se liga àquilo que é particular, que tem a ver com a "individualidade" de cada um. É desse modo que a subjetividade e sua constituição são tomadas como alvo da investigação.

Mostramos com nossa análise o entrelaçamento entre procedimento e relação. Surpreendentemente a maior parte das pesquisas realizadas por enfermeiros também se debruçam sobre o estudo da relação por meio do estudo sobre procedimentos. Cabe ressaltar que isso não aparece de modo declarado e proposital nesses trabalhos, mas sim como algo pressuposto no modo como tratam das relações, muito provavelmente sem se darem conta. Se estamos certos que não fazem de modo deliberado, também na pesquisa encontraríamos mais uma ocasião do efeito do jogo reconhecimento/desconhecimento.

Vieira e Silveira (2011) se dedicaram a estudar como aparece o cuidado e a clínica para o estudante de graduação de enfermagem. Os autores afirmam que ambos estariam como temas marginais ao curso universitário em questão. $\mathrm{O}$ cuidado seria entendido como o exercício humanizado da função do enfermeiro, a realização dos procedimentos visando um cuidado ao "sujeito" e não à doença. Já a clínica, seria os procedimentos mesmos. Concluem que para a comunidade pesquisada a clínica, quando aparece, é uma clínica da doença e não do cuidado. Chama-nos atenção o quanto o enfermeiro de nível superior parece estar distante do cuidado com o paciente, da clínica, e que parece haver uma tensão desde o ensino universitário entre a formação para a clínica e a formação para a gestão. É, inclusive, do pressuposto de que há uma predominância da formação para a gestão que a pesquisa parece partir e a que ela chega.

Como apresentamos em nossa análise, o meio de relação do enfermeiro no e com o trabalho se dá predominantemente em meio a procedimentos administrativos e gerenciais, mais que os "curativos" ou de "cuidado". Curiosamente, essa conclusão converge para o fato 
de encontrarmos predominantemente trabalhos na área administrativa e de gestão realizados por enfermeiros em nossa busca bibliográfica. Ou seja, se é verdade que a relação que o enfermeiro estabelece com o trabalho se constitui fundamentalmente numa relação via procedimentos administrativos e de gestão, é compreensível a ampla atenção dedicada a eles (procedimentos) nos estudos nessa área os quais, por sua vez, como num círculo vicioso próprio às instituições, acaba se tornando a linha predominante de ensino e pesquisa na universidade.

Azambuja et al. (2010), realizaram uma pesquisa em duas UTIs Adulto, uma delas de um hospital universitário e outra de um hospital filantrópico de um município no extremo sul do país. Baseando-se em conceitos da esquizoanálise e da psicodinâmica do trabalho acabam por elaborar um material analítico heterogêneo. Vale pontuar algumas afirmações das autoras que derivam de trechos selecionados das falas das entrevistadas:

Em relação aos Modelos de Gestão e Organização do Trabalho, apesar das diferenças encontradas nos dois hospitais, o trabalho da enfermagem tende a recair em organogramas verticalizados e na fragmentação das ações de trabalho, cabendo ao enfermeiro as ações mais relacionadas ao planejamento, organização e supervisão da assistência e aos técnicos e auxiliares de enfermagem, a execução das mesmas. (p. 661)

Esse discurso coincide com o que dissemos em nosso estudo, na medida em que aponta para uma divisão em dois grupos, o das técnicas e auxiliares e o das enfermeiras. Cabe acrescentar que tal divisão faz com que o grupo de técnicas tenha questões a respeito do trabalho que são distintas daquelas apresentadas pelo grupo de enfermeiras. Às primeiras se ligam principalmente as preocupações envolvendo procedimentos de "cuidado" e "curativos" e às enfermeiras os que se referem aos procedimentos administrativos e de gestão. Apesar de mostrarem essa divisão no trabalho, as autoras citadas tratam dessas questões sem realizar a devida distinção entre as mesmas. Em nossa análise vimos, por exemplo, como o problema da escala toca mais diretamente as enfermeiras que as técnicas e auxiliares. De todo modo, vale ressaltar que, nessa divisão, cada grupo continua exercendo da maneira que lhe cabe as práticas cujo alvo é o seu objeto institucional. Como vimos, o objeto institucional, cujo monopólio de legitimidade a instituição reivindica para si, definido para a Enfermagem por 
meio de nossa análise é a manutenção e controle de todos os movimentos e alterações do e no paciente, quer sejam motores ou fisiológicos, por meio de tecnologias de monitoramento e vigilância, gratificações e punições.

As mesmas autoras tocam em outro tema que se mostra relevante, mas não o aprofundam:

De uma maneira geral, os trabalhadores encaram a morte de pacientes mais idosos ou com patologias terminais que acarretam intenso sofrimento, como algo natural ou "até necessário". Porém, a morte de jovens ou crianças traz imenso desgaste e sofrimento. (Azambuja et al., 2010. p. 663)

Um trabalho que segue a mesma linha de investigação foi desenvolvido pelo Laboratório de Estudos sobre a Morte do Instituto de Psicologia da Universidade de São Paulo (LEM-IPUSP). Por meio do projeto Cuidando do Cuidador no Contexto Hospitalar (Kovács et al., 2008) realizaram o que denominaram Reuniões Temáticas com profissionais de enfermagem de diferentes Unidades de um Hospital Universitário, dentre elas a UTI Pediátrica e a Neo-natal, à qual o artigo citado se detém. Segundo as autoras, o grupo de enfermeiras mostrou uma forte identificação com o papel de mãe (em contraste com seu papel de profissional de enfermagem); medo intenso de forte vínculo com o paciente e a possibilidade de rompimento desse vínculo; a relação que o profissional desenvolve consigo próprio a partir da relação com o paciente; e "O inexorável: a morte", nas palavras das autoras, para dizer da relação que as profissionais estabeleciam com a morte.

Nossa pesquisa se deparou com as mesmas questões. Ao mesmo tempo acreditamos que avançamos ao traçar linhas de análise que ultrapassam o caráter descritivo das duas pesquisas acima mencionadas. Mostramos que a identificação com o papel de mãe aparece em íntima relação com os procedimentos que a profissional de enfermagem executa, sendo que, realizar os procedimentos que estariam previstos para a mãe faz com que "assumam [o paciente] no lugar da mãe". Essa indistinção entre fazer os procedimentos da mãe e assumir o papel de mãe parece ter origem no entrelaçamento entre procedimento e relação que apontamos como característico do modo de se relacionar desses profissionais. A indiferenciação entre fazer e ser acarreta indiferenciação entre papéis e relação bem como toda a carga afetiva constitutiva da mesma. 
Mostramos como toda a teia de relações estabelecidas pelas profissionais de enfermagem continha certo grau de indistinção, certa indefinição de limites que resultava na indistinção de papéis. A morte aparece, então, como o único limite inexorável. Ela desorganiza toda a cadeia de relações, inclusive aquela que o profissional estabelece consigo mesmo facilitada pela relação com o paciente. A morte acarreta descontrole de si e necessidade de reorganização subjetiva e da relação com o trabalho, tal qual pudemos acompanhar com Duzolina. Ao mesmo tempo pode se constituir como um trauma, produzindo invariavelmente a repetição da cena traumática no imaginário toda vez que o contexto favorece. Vimos isso no discurso de Laura quando fala de seu trauma e do pânico que sente toda vez que precisa trabalhar na UTI.

Nossa argumentação sobre esse aspecto da morte se ancora no modo como Duzolina se reorganiza após a experiência marcante da perda de forte vínculo. A profissional preconiza o estabelecimento de limites claros na relação com o paciente, e para isso propõe um funcionamento mecânico, automático e desapegado, para o exercício dos "cuidados de enfermagem", deixando do lado de fora do hospital aqueles que se ligam ao instinto e aos afetos. Ou seja, lidar com a morte é lidar com limites.

Seguindo por essa linha argumentativa, encontramos o mestrado de Boschco (2011), defendido no Programa de Pós-graduação em Psicologia da Universidade Federal do Paraná. Partindo do ponto de vista da psicologia do trabalho e com uma filiação teórica de base marxista, o autor estudou implicações do afastamento do trabalho na subjetividade de auxiliares de enfermagem. Aponta para a centralidade que o trabalho de enfermagem tem para os profissionais, e conclui:

A partir deste ofício cada uma das entrevistadas demonstrou o desenvolvimento de um estilo pessoal, produzindo para muito além de um serviço de enfermagem, a própria subjetividade. (p. 98)

A ruptura representada pelo afastamento do trabalho foi um momento pessoal para cada entrevistada e estava fortemente relacionada a vários sentidos e sentimentos como os de inutilidade, depressão, ansiedade, indignação, culpabilização, incompetência, revolta, humilhação e ressentimento. (p. 99)

Traesel e Merlo (2009) trabalharam em grupo com enfermeiras de um hospital geral da 
rede pública de uma cidade de porte médio do estado do Rio Grande do Sul. Todo o estudo se baseia na perspectiva da Psicodinâmica do Trabalho de Christophe Dejours. Os autores apresentam os resultados da pesquisa em meio a citações de outros autores, onde teoria e análise se confundem na apresentação que fazem dos resultados. De maneira geral, consideram o trabalho do enfermeiro como sendo de ordem imaterial e relacionam a essa característica a falta de limites claros entre o início e o fim das atividades, o que faria com que a atuação profissional extrapolasse o próprio papel profissional.

No contraste com nossa pesquisa, lançamos alguns questionamentos. Será que a falta de limites claros entre o início e o fim do trabalho e a "extrapolação" do papel profissional do enfermeiro na atuação profisssional se deve apenas à característica imaterial de seu trabalho? Todos os trabalhos de ordem imaterial apresentam essa falta de limites como característica na relação que o profissional desenvolve com o trabalho? Se a resposta a segunda pergunta é não, podemos dizer que provavelmente essa falta de limites não se deva exclusivamente à característica imaterial do trabalho. Nosso estudo mostra uma teia complexa de relações que tem como base um quê de indiferenciação na sua constituição. Em nossa opinião, a condição imaterial do trabalho, antes de ser a causa da falta de limites é ocasião de reedição de um modo característico de se constituir sujeito nessa instituição.

Para Traesel e Merlo (2009), ainda, outro fator de desgaste psíquico é o alto nível de responsabilidade por parte desses chefes de equipe de enfermagem. No polo oposto, consideram o reconhecimento no trabalho (no sentido de ser reconhecido e valorizado) como fonte importante para a promoção da saúde mental do trabalhador. Apontam que a principal fonte de reconhecimento para os profissionais é aquela proveniente do paciente, a melhora que ele apresenta após os cuidados recebidos. Paradoxalmente, afirmam os autores, a relação que as enfermeiras têm com o cuidado ao paciente é distante e as profissionais consideram a excessiva carga de trabalhos administrativos como causa desse distanciamento. Em um grau menor de importância viriam o reconhecimento por parte da direção, a remuneração adequada pelo trabalho, e o reconhecimento por parte dos subordinados por meio do bom relacionamento e cooperação por parte dos mesmos. Apontam, ainda, que as enfermeiras parecem "ter dificuldade em lidar com a complexidade do trabalho em equipe, com os desafios da liderança e com a cobrança de resultados de seus subordinados” (p. 106)

Em nossa análise vimos a questão da escala apresentada como o maior problema a ser enfrentado pelas profissionais. Concordamos com Trasel e Merlo (2009) e mostramos que se 
referia a algo que incomodava principalmente as enfermeiras, tratando-se de uma questão nas relações de poder. Analisamos os jogos de poder/resistência, identificamos polarizações e estratégias, encontramos um modo de decidir beligerante, pudemos ver o coordenador empenhado em sanar esses problemas, ou pelo menos ajudar, vimos como as profissionais resistem em ato, no grupo, na relação com o coordenador, deslegitimando-o, e por fim acompanhamos o grupo realizando uma função apaziguadora, de restabelecimento da ordem e do funcionamento institucional.

Ainda a respeito do reconhecimento, verificamos que para as participantes de nossa pesquisa o paciente característico da Pediatria é em si recompensador, pois ele chega ruim e sai bom. A velocidade e a frequência em que esse processo ocorre são relativamente superiores na comparação com outras clínicas. A Pediatria se configura como um lugar onde sempre há o que fazer, quando o paciente piora muito, ele é encaminhado à UTI. O paciente característico da pediatria é aquele que melhora, que torna-se saudável após os cuidados recebidos. A morte nessa Unidade é rara. Esses fatos fazem com que as participantes reconheçam a Pediatria como uma Clínica mais leve, mais alegre, com mais vida.

Outro estudo realizado por enfermeiras (Oliveira et al., 2006) parte do pressuposto declarado de que a equipe de enfermagem desconhece seu processo de trabalho e por esse motivo não presta cuidado humanizado. As autoras realizaram entrevistas semi-estruturadas com profissionais de enfermagem da UTI Neonatal de um Hospital Universitário no oeste do Paraná. As perguntas aparecem de modo categórico e as pesquisadoras parecem esperar respostas "teóricas" por parte dos entrevistados. Por exemplo, solicitam que o entrevistado diga qual o seu objeto de trabalho, e as respostas que não correspondem à teoria são "erradas", mostram "desconhecimento" dos profissionais, segundo as autoras. As conclusões do artigo são normativas. Concluem que os profissionais têm uma visão fragmentada dos seus instrumentos de trabalho e dizem, na sequencia, como deveria ser. Os resultados da pesquisa confirmam o pressuposto das autoras que parecem realizá-la como uma avaliação dos profissionais, se atendo àquilo que "não sabem", deixando apagado o como os entrevistados concebem e exercem cotidianamente o trabalho. A pesquisa se atém ao que "falta", como se a teoria fosse sede de toda a verdade, estando nela e apenas nela, a possibilidade de promoção de "coisas boas". As autoras realizam um check list comparando as respostas dos entrevistados ao conteúdo descrito na teoria. Como diria Foucault (1970/2009) trata-se de um comentário da teoria, onde nada novo se produz. Não há análise, apenas a repetição do que já 
fora dito antes.

A partir da análise e discussão dos depoimentos da equipe de enfermagem, observamos que esta não compreende qual o seu objeto de trabalho, evidenciando que o foco da assistência, devido à alta tecnologia e desenvolvimento de materiais e máquinas, se focaliza nestes instrumentos como sendo o objeto de seu trabalho.

A finalidade do trabalho ou o próprio trabalho de enfermagem é o "plano" para modificação do objeto, utilizando os instrumentos, almejando o produto final. O trabalho de Enfermagem tem como finalidade a recuperação do paciente por meio do cuidado/assistência, à ação terapêutica de saúde, organizando e controlando o processo de trabalho, favorecendo a ação de "cuidar" para possibilitar a cura. Para que haja a cura e recuperação do bebê é necessário que a enfermagem, e a equipe de saúde como um todo, realize uma assistência de qualidade, buscando a integralidade a fim de ampliar a clínica empobrecida que vem sendo desenvolvida, incluindo-se a família na perspectiva do cuidado. (Oliveira et al., 2006, p. 111)

O objeto está definido a priori e o que as autoras "encontram" nas entrevistas é tomado de modo descontextualizado, sem levar em conta, por exemplo, a maneira como foram realizadas as perguntas.

Ao analisarmos o que o artigo preconiza por meio da teoria que defende, verificamos que o objeto por ele definido para a Enfermagem se aproxima daquele por nós configurado como produto de nossa análise, "organizando e controlando o processo de trabalho, favorecendo a ação de 'cuidar' para possibilitar a cura".

Também nesse ponto mostramos algo que acrescenta na compreensão. Todos os movimentos e alterações, motoras e fisiológicas, do paciente, bem como da mãe - na medida em que esta é uma extensão do paciente e dos cuidados de enfermagem - estão considerados no "processo de trabalho" da equipe de enfermagem. Vimos também as técnicas utilizadas para se atingir a esses objetivos. Contudo, mostramos a realidade das profissionais pesquisadas por nós, naquele contexto específico. Esse "como", que seria a parte mais interessante do estudo (Oliveira et al., 2006) não é contemplado pelas autoras. 


\section{Considerações finais}

A Analise Institucional do Discurso mostrou-se um método fecundo à investigação que nos propusemos. Com a proposta ficar atento à superfície mesma do discurso, às praticas e relações sociais tal qual imaginadas por aqueles que as fazem (Guirado, 2010), fomos traçando paulatinamente os elementos que constituíam a relação que as profissionais de enfermagem desenvolvem com o trabalho. Por vezes as afirmações analíticas nos pareciam até certo ponto óbvias, dado a fidelidade ao que se mostrava pelo discurso, acompanhando-o em sua concretude opaca - e não transparente (Guirado, 2010). A concretude que impede ver algo além do discurso mesmo. Por vezes nossas análises pareciam ser nada mais que a observação rigorosa feita por uma pessoa atenta. E, grosso modo, era isso mesmo. Grosso modo, porque se tratava de uma observação fundada numa estratégia para conhecer aquilo que se nos apresentava, um jeito específico de conceber como se constitui a subjetividade a partir de conceitos bem definidos de instituição, discurso e análise. Um modo de produção de conhecimento que determinou o que produzimos, tal qual todo método determina. Essa determinação, contudo, fica mais evidente no momento em que buscamos outras pesquisas na área para traçar interlocuções. Percebemos que de algum modo nossa análise adensou a complexidade das questões levantadas e possibilitou esboçar uma linha argumentativa diferenciada das que encontramos. Isso por si só, a nosso ver, vem a contribuir com estudos que tenham como alvo de investigação o trabalho de profissionais de enfermagem e/ou saúde, relações na pediatria e/ou hospital como um todo, bem como a relação com a clientela da instituição hospitalar.

Nesse sentido, seria prudente tomar os resultados por nós apresentados como referentes ao contexto específico do hospital e da unidade pesquisada, evitando-se, sempre, a generalização. Que, então, a atenção voltada a essa pesquisa recaia sobre o modo como o conhecimento foi produzido, muito mais do que ao produto dela em si, para que ela possa funcionar como um corte que faz pensar (Guirado, 2010). Esperamos que esse estudo propicie a mobilização do pensar e seja ocasião de abertura para outras análises que se debrucem, de fato, sobre o fazer concreto dos profissionais; que seja, enfim, reconhecido como denunciador do caráter "produzido" daquilo que é tido como natural, e assim seja possibilidade de se começar a pensar que é possível fazer e ser diferente. 


\section{Referências*}

Austin, J. L. (1990). Quando dizer é fazer. Porto Alegre: Artes Médicas. (Trabalho original publicado em 1962)

Azambuja, E.P., Pires, D.E.P., Vaz, M.R.C., \& Marziale, M.H. (2010 Out/Dez). É possível produzir saúde no trabalho da enfermagem? [Versão eletrônica] Texto Contexto Enfermagem, Florianópolis, 19(4), 658-66.

Boschco, C. R. (2011). Implicações do afastamento do trabalho por adoecimento na subjetividade do auxiliar de enfermagem. Dissertação de Mestrado, Setor de Ciências Humanas, Letras e Artes, Universidade Federal do Paraná. Curitiba, Paraná.

Brotta, M.S., \& Castro, P.F. (2012 Jul/Dez). Produção Científica Sobre Avaliação Psicológica em Psicologia Hospitalar. [Versão eletrônica] Revista Iniciação Científica CESUMAR, 14(2), 199-211

Campos, J.F., \& David, H.S.L. (2011). Avaliação do contexto de trabalho em terapia intensiva sob o olhar da psicodinâmica do trabalho. [Versão eletrônica] Revista Escola de Enfermagem USP, 45(2), 363-8. Recuperado em 12 de fevereiro de 2013, de www.ee.usp.br/reeusp/

Foucault, M. (1990). História da sexualidade 1: vontade de saber. (10a ed.) Rio de Janeiro: Graal.

Foucault, M. (1995). Sujeito e Poder In Dreyfus, H.; Rabinow, P. Michel Foucault: uma trajetória filosófica para além do estruturalismo e da hermenêtica. Rio de Janeiro: Forense Universitária.

Foucault, M. (2004) Ditos e Escritos V: ética, sexualidade, política. Rio de Janeiro: Forense

* De acordo com o estilo APA - American Psychological Association 
Universitária.

Foucault, M. (2009) A ordem do discurso. (18a ed.) São Paulo: Loyola. (Trabalho original publicado em 1970)

Foucault, M. (2011) O Nascimento da Clínica. (7a ed.) Rio de Janeiro: Forense Universitária.

Freud, S. (2010). A dinâmica da transferência. In Obras Completas.(Vol. 10, pp. 133-146). São Paulo: Companhia das Letras,. (Trabalho original publicado em 1912)

Freud, S. (2011). Nota sobre o “bloco mágico”. In Obras Completas. (Vol. 16, pp267-274). São Paulo: Companhia das Letras. (Trabalho original publicado em 1925)

Guilhon Albuquerque, J. A. (1980) Instituição e Poder. Rio de Janeiro: Graal,.

Guirado, M. (2000). A clínica psicanalítica na sombra do discurso. São Paulo: Casa do Psicólogo.

Guirado, M. (2004a). Psicologia institucional. 2. ed. São Paulo: EPU.

Guirado, M. (2004b). Instituição e relações afetivas: o vínculo com o abandono. São Paulo: Casa do Psicólogo.

Guirado, M. (2006). Psicanálise e Análise do Discurso: matrizes institucionais do sujeito psíquico. 2. ed. São Paulo: EPU.

Guirado, M., \& Lerner, R. (Orgs.) (2007). Psicologia, pesquisa e clínica - por uma análise institucional do discurso. São Paulo: Annablume; FAPESP.

Guirado, M. (2009). Análise Institucional do discurso como analitica da subjetividade. Tese de Livre Docência, Instituto de Psicologia, Universidade de São Paulo, São Paulo.

Guirado, M. (2010). Análise Institucional do discurso como analítica da subjetividade. São 
Paulo: Annablume.

Kovács, M.J., Esslinger, I., Vaiciunas, N., \& Souza, T.M. (2008 Jan/Mar). Cuidando do Cuidador em UTIs Pediátrica e Neo-natal. [Versão eletrônica] O Mundo da Saúde São Paulo: 32(1), 24-30.

Magnago, T.S.B.S., Lisboa, M.T.L., Griep, R.H., Zeitoune, R.C.G., \& Tavares, J.P. (2010). Condições de trabalho de profissionais da enfermagem: avaliação baseada no modelo demanda-controle. [Versão eletrônica]. Acta Paul Enfermagem, 23(6), 811-7.

Nogueira-Martins, L.A. (2010) Interconsulta Hoje. In Mello Filho, J. (org.) Psicossomática hoje. Porto Alegre: Artes Médicas.

Oliveira, B.R.G., Lopes, T.A., Viera, C.S., \& Collet. N. (2006). O processo de trabalho da equipe de enfermagem na UTI neonatal e o cuidar humanizado. [Versão eletrônica] Texto Contexto Enfermagem, Florianópolis, 15(Esp), 105-13.

Peixoto, T.C., Brito, M.J.M., \& Santana, L.C. (2012 Out/Dez). Gestão de pessoas em uma unidade pediátrica na perspectiva do diagnóstico ONA e de profissionais. Revista Eletrônica de Enfermagem, 14(4), 893-902. Recuperado em 12 de fevereiro de 2013, de http://www.fen.ufg.br/revista/v14/n4/v14n4a18.htm.

Pinho, D. L. M.; Abrahão, J. I., \& Ferreira, M.C. (2003 Mar/Abr). As estratégias operatórias e a gestão da informação no trabalho de enfermagem, no contexto hospitalar. [Versão eletrônica]. Revista Latino-americana de Enfermagem, 11(2),168-76.

Souza, G.C. (2011). Trabalho em equipe de enfermagem: interação, conflito e ação interpessoal em hospital especializado. Dissertação de Mestrado, Escola de Enfermagem, Universidade de São Paulo, São Paulo.

Traesel, E. S., \& Merlo, A. R. C. (2009 Jan/Mar). A psicodinâmica do reconhecimento no trabalho de enfermagem. Psico, Porto Alegre, PUCRS, v. 40, n. 1, pp. 102-109, 
Vídeo CRP-SP Uma questão de Saúde: Trajetória da Psicologia Hospitalar em São Paulo. Recuperado em 22 de setembro de 2009, de http://www.crpsp.org.br/memoria/trajetoria/resumo trajetoria.aspx

Vieira, A.N., \& Silveira, L.C. (2011 Out/Dez). Cuidado e clínica na formação do enfermeiro. [Versão eletrônica] Escola Anna Nery, 15 (4), 776-783 
Apêndice 


\section{Termo de Consentimento Livre e Esclarecido}

Proposta: Eu, Ronaldo Lopes Coelho, orientado por Marlene Guirado, respectivamente, mestrando e professora e pesquisadora do Instituto de Psicologia da Universidade de São Paulo, estou realizando a pesquisa "Análise de uma intervenção institucional junto aos profissionais de um Hospital-Escola”. O trabalho consiste na realização de cinco reuniões com os profissionais da enfermaria da pediatria deste hospital no intuito de discutirmos a respeito do cotidiano de trabalho, as experiências, as dificuldades e as estratégias que se têm encontrado para lidar com elas. As reuniões serão gravadas em áudio e transcritas para podermos realizar a análise do material. Com isso pretendemos proporcionar aos profissionais esse espaço de reflexão sobre as práticas e sobre a relação que mantém com o trabalho que desenvolvem; contribuir no debate sobre propostas de intervenção em análise institucional e, também, no campo do trabalho de profissionais de saúde, ao construirmos um saber sobre uma configuração institucional possível e suas implicações.

Convite: Você está sendo convidado a participar desta pesquisa porque faz parte da equipe de enfermagem da enfermaria da pediatria do hospital em que o estudo será realizado. A sua participação é voluntária e você tem o direito de desistir da participação em qualquer momento.

Procedimentos: Sua participação nesta pesquisa requer sua presença nas cinco reuniões, que acontecerão com periodicidade semanal, e seu consentimento para a gravação das mesmas. $\mathrm{O}$ material gravado será transcrito e analisado. Tanto as transcrições quanto as gravações serão mantidas em sigilo sob posse deste pesquisador.

Sigilo: Sua identidade será resguardada, bem como qualquer tipo de identificação mencionados, direta ou indiretamente. Ressaltamos, ainda, que nenhuma informação será cedida a outros profissionais desta instituição, mantendo-se, assim, o sigilo com relação ao que trataremos nos encontros.

Benefício: A pesquisa é uma oportunidade de refletir sobre o trabalho realizado na enfermaria da pediatria deste hospital-escola, bem como sobre a relação que cada um mantém com seu 
trabalho, em diversas dimensões. É, também, uma ocasião para que as opiniões e vivências dos profissionais sejam registradas e divulgadas, buscando, com isso, elaborar e propor conjuntamente com esses profissionais formas de re-significar as práticas, as relações e a organização do trabalho.

Ressarcimento: Sua participação é voluntária e não compreende nenhum ganho financeiro, bem como nenhuma despesa de mesma natureza. Informamos, ainda, que conforme a resolução n. ${ }^{\circ}$ 016/2000 do Conselho Federal de Psicologia, nos responsabilizamos e dispomos de meios e competências para identificar e lidar com eventuais consequências de nosso procedimento de intervenção, ou seja, nas reuniões, por exemplo, no caso do aumento ou geração de angústia devido à narrativa de acontecimentos potencialmente traumáticos ou conflitos entre profissionais. Nesse sentido, caso seja identificada a necessidade de continuidade do trabalho, seja em grupo ou em outra modalidade de atenção, nos dispomos a fazê-lo ou mesmo encaminhar a um profissional capacitado para tal, assegurando a gratuidade de todo e qualquer atendimento.

Resultados: Os resultados serão utilizados para a confecção da dissertação de mestrado e possivelmente para a produção de material de divulgação científica, tais como artigos e/ou livros. Assegurado o anonimato, tal como mencionado no subitem Sigilo.

Questões: Todos poderão pedir os esclarecimentos que desejarem e/ou deixar a pesquisa a qualquer momento, retirando seu consentimento, sem quaisquer consequências, penalizações ou prejuízos. Faça todas as perguntas que achar necessárias antes de decidir participar e de assinar este documento.

Qualquer questão, dúvida, esclarecimento ou reclamação sobre os aspectos éticos dessa pesquisa, favor entrar em contato com:

- Comitê de Ética em Pesquisa do Hospital Universitário: Av. Prof. Lineu Prestes, 2565 - Cidade Universitária - CEP: 05508-000 - São Paulo - SP - Brasil. Telefone: 30919457 - Fax: 3091-9452 - E-mail: cep@hu.usp.br

- Comitê de Ética em Pesquisa com Seres Humanos do Instituto de Psicologia: Av. Prof. Mello Moraes, 1721 - Bloco G - Sala 22 - Cidade Universitária - 05508-030 - São 
Paulo - SP - Brasil. Telefone: 3097-0529 - E-mail: ceph.ip@usp.br

Maiores esclarecimentos poderão ser obtidos com o pesquisador Ronaldo Lopes Coelho. Telefone: 9494-5458 - E-mail: ronaldo.coelho@usp.br; ou com a Prof ${ }^{\mathrm{a}}$ Dr $^{\mathrm{a}}$ Marlene Guirado, Telefone: 5051-0020 E-mail: mguirado@terra.com.br

Consentimento: Declaro que, após convenientemente esclarecido pelo pesquisador e ter entendido o que me foi explicado, consinto em participar do presente Projeto de Pesquisa.

\section{Identificação:}

Nome:

RG:

Sexo:

Data de Nascimento:

Endereço:

Bairro:

CEP:

Telefone:

São Paulo, de de 2010

Assinatura:

Ronaldo Lopes Coelho

Mestrando IP-USP
Marlene Guirado

Prof $^{a}$ Associada IP-USP

Este TCLE trata-se de um documento feito em duas vias. Uma delas permanecerá em poder do participante, e a outra sob posse do pesquisador. 